INTERNATIONAL MONETARY FUND

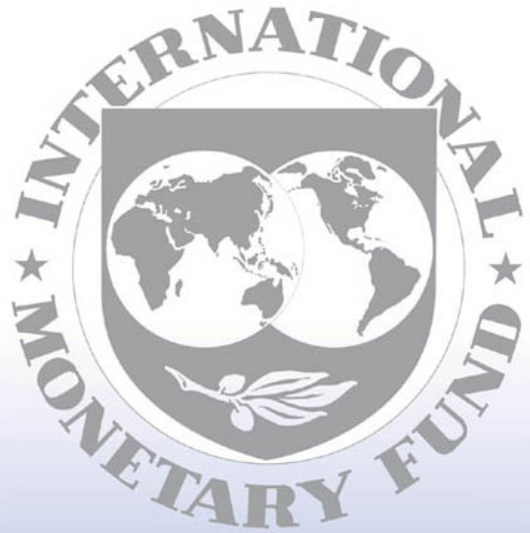

Staff

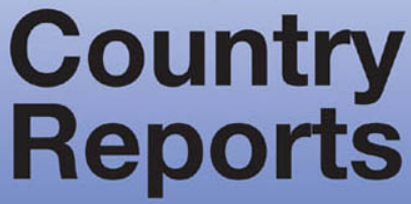




\section{Republic of Congo: Selected Issues and Statistical Appendix}

This Selected Issues paper and Statistical Appendix for the Republic of Congo was prepared by a staff team of the International Monetary Fund as background documentation for the periodic consultation with the member country. It is based on the information available at the time it was completed on May 21, 2004. The views expressed in this document are those of the staff team and do not necessarily reflect the views of the government of the Republic of Congo or the Executive Board of the IMF.

The policy of publication of staff reports and other documents by the IMF allows for the deletion of market-sensitive information.

To assist the IMF in evaluating the publication policy, reader comments are invited and may be sent by e-mail to publicationpolicy@imf.org.

Copies of this report are available to the public from

International Monetary Fund • Publication Services

700 19th Street, N.W. • Washington, D.C. 20431

Telephone: (202) 6237430 • Telefax: (202) 6237201

E-mail: publications@imf.org • Internet: http://www.imf.org

Price: $\$ 15.00$ a copy

\section{International Monetary Fund \\ Washington, D.C.}


This page intentionally left blank 


\section{INTERNATIONAL MONETARY FUND \\ REPUBLIC OF CONGO}

\section{Selected Issues and Statistical Appendix}

Prepared by a staff team consisting of Mr. Ghura (head), Mr. Leite, Mr. Karangwa (all AFR), Mr. Op de Beke (PDR), and Mr. Moussa (FAD)

Approved by the African Department

May 21, 2004

Contents

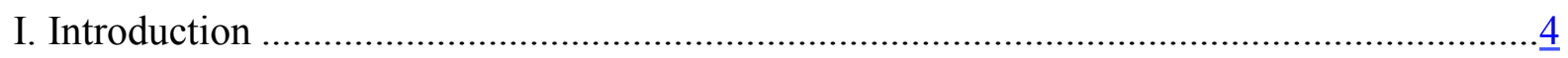

II. Political and Security Situation ....................................................................................

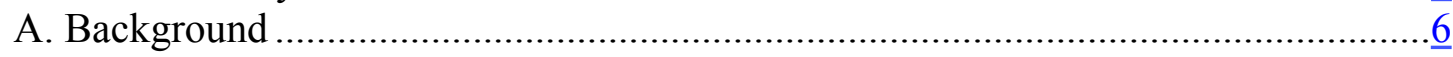

B. Recent Developments.........................................................................................

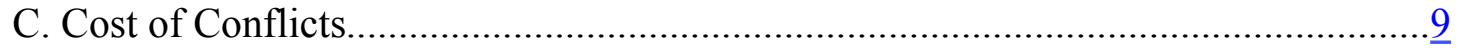

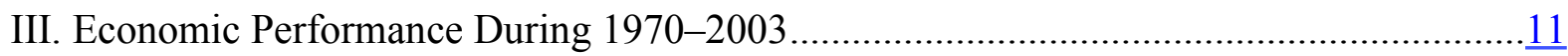

A. Output Expansion, 1970-84 .........................................................................

B. Output Collapse, 1985-99 ………..................................................................

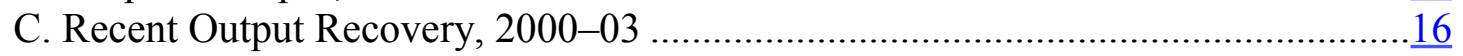

D. Observations and Evaluation ...........................................................................17

IV. Recent Reforms in Public Finance Management.............................................................20

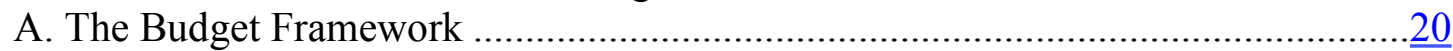

B. Revenue Mobilization ……………………….............................................21

C. Expenditure and Cash Management.....................................................................

D. Future Steps ...................................................................................................22

V. Constraints to Economic Growth and Poverty Reduction ..............................................24

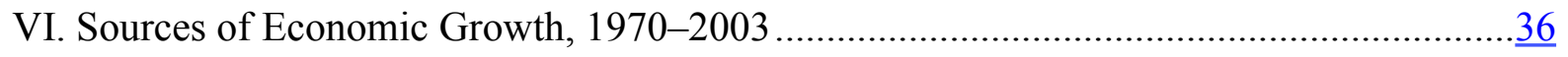

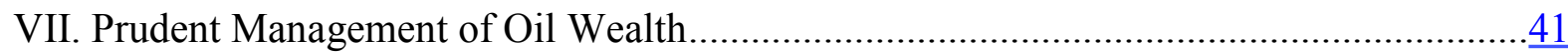

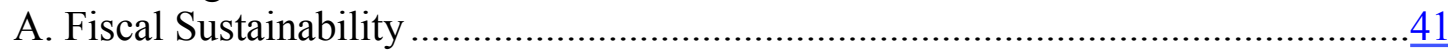

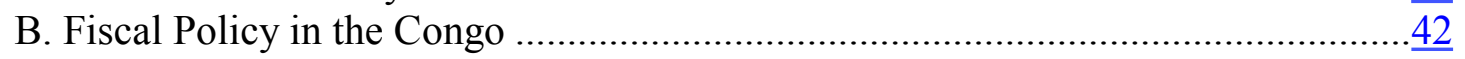

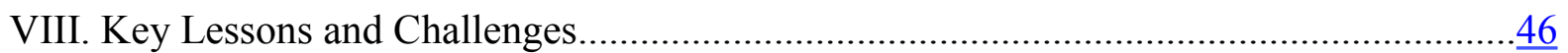

A. Avoiding Conflicts ..................................................................................

B. Avoiding Pro-Cyclical Government Spending ………........................................ 46 
C. Promoting Private Sector Growth $\underline{47}$

D. Alleviating the Debt Burden

Boxes

II.1. Chronology of Key Political Events Since Independence ....................................

III.1. Performance Under Fund Programs, 1986-2003 .............................................13

III.2. Program Implementation in 2003 ................................................................

Tables

II.1. Selected Economic and Social Indicators, 1970-2003 ......................................10

III.1. Selected Indicators of Economic Performance, 1970-2003 .................................12a

V.1. Cross Section Comparative Economic and Social Performance: 1970-99 ................34

V.2. Cross Section and Time Series Comparative Economic and Social Performance: 1970-99 .................................................................

VI.1 Sources of Growth: 1970-2003 .................................................................

VII.1 Fiscal Sustainability Approach Based on Intergenerational Objectives, 2003-13 ..... $\underline{45}$

Figures

III.1. Macroeconomic Performance, 1970-2003 ....................................................12

III.2. Selected Economic Indicators, 1970-2003 ................................................... 17

III.3. Oil Price, Government Spending, and Non-Oil Output, 1975-2003 .......................18

V.1. Per Capita GDP: Republic of Congo and Comparator Groups, 1970-2001 ..............24

V.2. Per Capita Real GDP Growth: Republic of Congo and Comparator Groups, 1970-99 ..................................................................25

V.3. Natural Resource Dependence: Republic of Congo and Comparator Groups, 1970-99 ................................................................. 26

V.4. Government Size: Republic of Congo and Comparator Groups, 1970-99 ...............26

V.5. Financial Depth: Republic of Congo and Comparator Groups, 1970-99 .................27

V.6. Adult Illiteracy Ratio: Republic of Congo and Comparator Groups, 1970-99 ...........28

V.7. Secondary School Enrollment Ratio: Republic of Congo and Comparator Groups, 1970-99 .29

V.8. Life Expectancy at Birth: Republic of Congo and Comparator Groups, 1970-99 .....29

V.9. External Debt: Republic of Congo and Comparator Groups, 1970-99 .................... $\underline{30}$

V.10 Institutions and Governance: Republic of Congo and Comparator Groups, $2002 \ldots . . .31$

VI.1. Sources of Economic Growth, 1975-2003 .......................................................

Statistical Appendix Tables

Basic Data, 1997-2003 $\underline{49}$

1. Gross Domestic Product at Constant 1990 Prices, 1997-2003.....................................53

2. Gross Domestic Product at Current Prices, 1997-2003 .............................................54

3. Supply and Use of Resources at Constant 1990 Prices, 1997-2003.............................55

4. Supply and Use of Resources at Current Prices, 1997-2003 .....................................56

5. Saving and Investment Balances, 1996-2003 .........................................................57

6. Production of Principal Crops, 1996/97-2002/03 .....................................................58

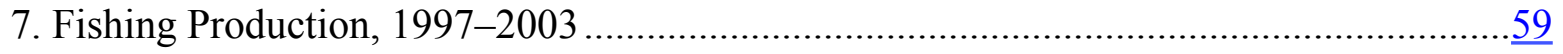

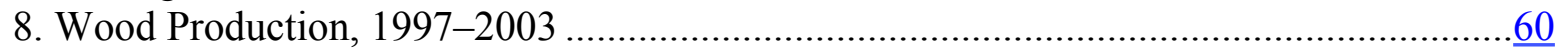




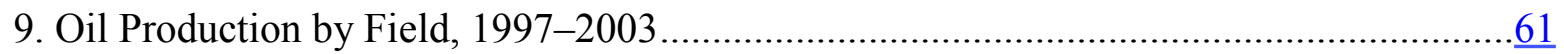

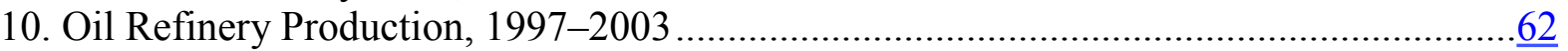

11. Consumption of Refined Petroleum Products, 1997-2003 ..............................................63

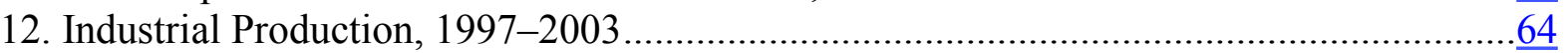

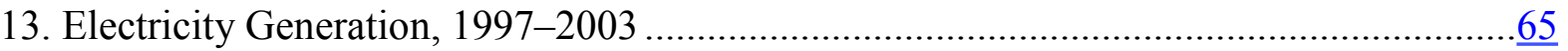

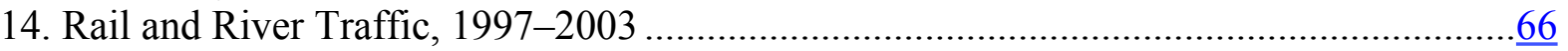

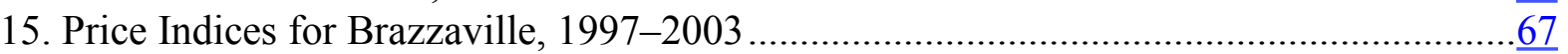

16. Representative Retail Prices of Major Food Items in Brazzaville, 1997-2003 ………...... 68

17. Central Government Employment by Ministry, 1997-2003 ………………....................69

18. Central Government Financial Operations, 1997-2003 ………......................................

19. Central Government Revenue, 1997-2003 ............................................................

20. Central Government Revenue Trends, 1997-2003 ……...........................................

21. Central Government Expenditure Trends, 1997-2003 ………...................................

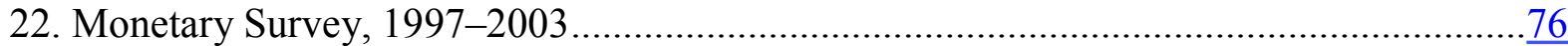

23. Summary Accounts of the Central Bank, 1997-2003 ..................................................77

24. Summary Accounts of the Commercial Banks, 1997-2003 ............................................78

25. Interest Rate Structure, 1997-2003 .......................................................................

26. Balance of Payments, 1997-2003 ………………..................................................

27. Balance of Payments of the Oil and Non-Oil Sectors, 1999-2003 ..................................

28. Composition of Exports, 1997-2003 …………...................................................

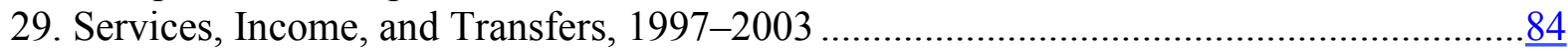

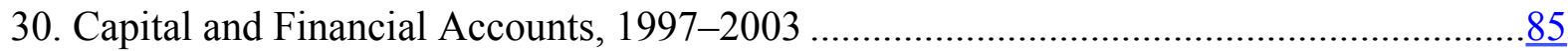

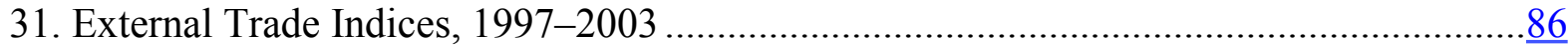

32. External Public Debt and Debt Service, 1997-2003 ....................................................

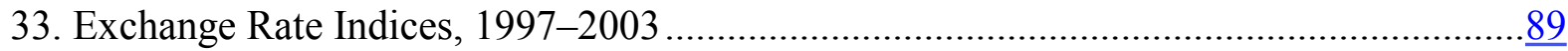

Appendix

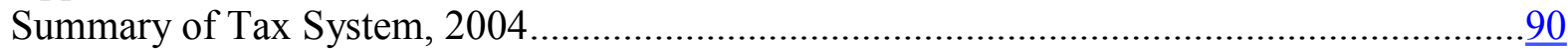




\section{INTRODUCTION}

1. The Republic of Congo (hereafter "the Congo"), ${ }^{1}$ the fourth-largest oil producer in sub-Saharan Africa, is emerging from three successive civil conflicts in the 1990s. Once classified as a lower-middle-income economy, the Congo has experienced an almost continuous decline in per capita income over the past 15 years or so. This negative trend coincided with the overvaluation of the CFA franc in the second half of the 1980s and early 1990s, an acceleration of rural-urban migration in the 1980s, and three conflicts in the 1990s. In addition, non-oil output growth has been constrained by the heavy dependence on the oil sector, poor infrastructure, and high cost of public utilities, as well as weak institutions, poor governance, and a legacy of central planning and associated antibusiness bias.

2. The Congolese economy is dominated by the oil sector, which accounts for about 50 percent of GDP, 70 percent of government revenues, and 80 percent of exports. Oil production is mainly located offshore and managed by joint ventures between foreign companies and the national oil company (Société Nationale des Pétroles du Congo, SNPC). Ancillary oil-related services are dominated by foreign groups, and the bulk of their supplies are imported. The non-oil sector is composed of a mixture of forestry, traditional agriculture, services, and a relatively large public administration. The Congo's forests, which cover about half of the country, account for less than 5 percent of GDP but constitute almost two-thirds of non-oil exports. Agriculture employs about one-third of the active population and accounts for another 5 percent of GDP. It consists mainly of subsistence activities by smallholders, with relatively little commercialization (in part due to poor access roads) and limited export activities. Food imports, which have increased significantly since the 1980 s, account for about one-third of total imports.

3. The Congo was under a socialist one-party system and the economy was centrally planned during 1964-90. The transition to a democratic state came through a tumultuous, conflict-ridden phase in the 1990s; three successive and intense conflicts destroyed physical capital, displaced thousands of individuals, and further weakened institutions. Recent developments on the political front are encouraging against the background of recurrent conflicts in the 1990s. Under the umbrella of peace, the Congo completed a four-year political transition period, held democratic elections, and installed the full complement of democratic institutions required by the Constitution.

\footnotetext{
${ }^{1}$ The Congo is a member of the French franc zone. Its currency, the franc de la Communauté Financière en Afrique Centrale (the CFA franc), is issued by the Banque des Etats de l'Afrique Centrale (BEAC) and is pegged to the euro. The exchange rate of the CFA franc in terms of the French franc, which had been fixed since 1948, was devalued by 50 percent in foreign currency terms in January 1994, thus changing the parity from CFAF $1=\mathrm{F} 0.02$ to CFAF $1=$ F 0.01. Since January 1999, the CFA franc has been pegged to the euro at the fixed rate of $€ 1=$ CFAF 655.957.
} 
4. Accompanying the recent positive momentum on the political front, economic activity in the non-oil sector has picked up and inflation has decelerated. Nonetheless, key social indicators have continued to deteriorate, and the external debt burden is heavy. Building on the momentum generated by the improvements on the political and economic fronts, the government has begun focusing on economic management.

5. The rest of this paper is organized as follows: Section II outlines the recent developments in the political and security situation; Section III reviews economic performance during 1970-2003, including in the context of Fund-supported programs, Section IV reviews recent developments in public finance management, Section V examines the constraints on growth and poverty reduction, Section VI analyzes the sources of economic growth during 1970-2003, Section VII discusses the feasibility of an oil fiscal rule, and Section VIII notes some key lessons and challenges for the Congo. 


\section{Political And Security Situation ${ }^{2}$}

\section{A. Background ${ }^{3}$}

6. After three relatively peaceful but coup-ridden decades of independence, the Republic of the Congo (hereafter "the Congo") experienced three intense conflicts in the 1990s (1993, 1997, and 1998-99) — see Box II.1 for a time line of key political events. After an already turbulent first half of the 1990s, due principally to disputes over elections, political turmoil intensified after 1996 and two civil wars (in 1997 and late 1998) ravaged the southern part of the country. In various combinations, these conflicts opposed the regular armed forces and three main militias (the "Cobras" of President Denis Sassou Nguesso, the "Coyotes" and the "Zulus" of the former President, Pascal Lissouba, and the "Ninjas" of Bernard Kolelas and Pastor Ntumi).

- $\quad$ Fighting erupted in 1993 when disputed parliamentary elections led to ethnically based fighting between progovernment forces and the opposition. A cease-fire agreement was followed, during 1994-95, by the inclusion of some opposition members in the government.

- In 1997, ethnic and political tensions exploded into a full-scale civil war, fueled in part by the prize of the country's offshore oil wealth, which may have motivated warlords. The army split along ethnic lines, with most northern officers joining President Sassou Nguesso's side and most southerners backing the rebels. These were supporters of Pascal Lissouba, and his Prime Minister, Bernard Kolelas, who had been deposed by Sassou Nguesso in 1997. The new President appointed a government of "national unity" of 33 members in November 1997, and the government convened a National Forum of Reconciliation in January 1998. The new government implemented a three-month emergency program, with support from several UN agencies, the European Union, France, and nongovernmental organizations. The main objective was to respond to the pressing needs of the Brazzaville population in terms of security, health, food, and shelter, and to begin to rebuild the nation's institutional, administrative, and statistical capacity.

- $\quad$ The conflict of December 1998-October 1999 affected mainly the southern part of the country. Following the 1998-99 conflict, a cease-fire agreement was signed in late 1999 , that provided for a national dialogue, demilitarization of political parties, and the reorganization of the army, including the readmission of rebel units into the security forces.

\footnotetext{
2 This section was prepared by Dhaneshwar Ghura and Carlos Leite.

${ }^{3}$ Source: http://news.bbc.co.uk/1/hi/world/africa/country_profiles/1076794.stm
} 


\section{Box II.1. Republic of Congo: Chronology of Key Political Events Since Independence ${ }^{1}$}

1960: The Congo becomes independent with Fulbert Youlou as President.

1963: President Youlou is forced to resign following workers' unrest; Alphonse MassambaDebat becomes President and Pascal Lissouba prime minister.

1968: $\quad$ President Massamba-Debat is ousted in a coup led by Marien Ngouabi, who continues his predecessor's commitment to socialism but sets up his own party, the Congolese Workers Party (PCT).

1970: $\quad$ President Ngouabi proclaims the Congo a Marxist People's Republic, with the PCT as the sole legitimate party.

1977: $\quad$ President Ngouabi is assassinated in a plot by Massamba-Debat, who in turn is executed; Joachim Yhombi-Opango becomes President.

1979: President Yhombi-Opango hands over the presidency to the PCT, which chooses Denis Sassou Nguesso as his successor.

1990: $\quad$ The PCT abandons Marxism.

1992: Voters approve a new Constitution establishing a multiparty system; Pascal Lissouba elected President in the Congo's first democratic election.

1993: Bloody fighting erupts between government forces and opposition over disputed parliamentary elections.

1994-95: $\quad$ Cease-fire between government and opposition established; opposition given government posts.

1997: Full-scale civil war breaks out; pro-Sassou Nguesso forces, aided by Angolan troops, capture the capital, Brazzaville, forcing Lissouba to flee.

1999: Government and rebels sign a peace deal in the Zambian capital, Lusaka, providing for a national dialogue, demilitarization of political parties, and the readmission of rebel units into the country's security apparatus.

2001 Apr.: $\quad$ Peace conference ends by adopting a new Constitution that will be put to a referendum at the end of the year, paving the way for presidential and parliamentary elections.

2001 Sep.: Transitional parliament adopts a draft Constitution. Some 15,000 militia are disarmed in a cash-for-arms scheme.

2001 Dec.: Former President Pascal Lissouba is convicted in absentia on treason and corruption charges, and sentenced to 30 years' hard labor by the High Court in Brazzaville.

2002 Jan.: Official results indicate that about 80 percent of voters in the constitutional referendum approved amendments aimed at consolidating presidential powers.

2002 Mar.: $\quad$ Sassou Nguesso wins presidential elections unopposed after his main rivals are barred from the contest. Intense fighting between government and "Ninja" rebels drives many thousands of civilians from their homes in the Pool region. The rebels, loyal to former Prime Minister Bernard Kolelas and led by a Pastor Ntumi, name themselves after the famous Japanese warriors.

2002 Jun: $\quad$ Government troops battle Ninja rebels in Brazzaville. About 100 people are killed in some of the worst fighting seen in the capital in years.

2003 Mar: Government signs agreements with Ninja rebels, aimed at ending fighting in Pool region. Pastor Ntumi agrees to end hostilities and allow the return of the rule of law. 


\section{B. Recent Developments}

7. The national dialogue that followed the 1999 cease-fire offered an opportunity for drafting a new Constitution in 2001. President Sassou Nguesso consolidated his power base, and postwar reconstruction was undertaken, along with the reintegration of former militiamen into the society, with the support of the international community. The new constitution, adopted by referendum in January 2002, strengthened the power of the president. Presidential, legislative, local and senatorial elections were held during MarchJuly 2002, although the main political challengers and former leaders were excluded. The inauguration of President Sassou Nguesso in August 2002 put a formal end to the four-year transition period. Subsequently, a new government, was empowered to implement a policy agenda popularly known as New Hope (Nouvelle Esperance).

8. Renewed activity from a rebel group in 2002 dealt a setback to efforts on peace consolidation and political normalization. The Pool region (including Brazzaville) was destabilized by (i) the resumption of military activity in the spring of 2002, (ii) strikes carried out by the Ninja rebel group (led by Pastor Ntumi) until October 2002, and (iii) the response of the regular army to the aggression. Thousands of people were forced to flee their homes, creating a humanitarian crisis. Efforts to restore peace succeeded with the signing on March 17, 2003 of a new peace accord that recommitted the government and the Ninja rebel group to the 1999 agreement. Accordingly, the rebels undertook to surrender their arms, and the government undertook to re-integrate their members into civil society under the ongoing demobilization and reintegration program.

9. Recent developments on the security front have helped to consolidate the political stability and military peace achieved in the aftermath of the 2002 elections and the 2003 peace accord, including:

- $\quad$ the approval in August-2003 of amnesty provisions for both rebel and government combatants.

- The promulgation, on November 12, 2003, of the program for the demobilization, disarmament, and reinsertion of former combatants.

10. With security restored in the area surrounding Brazzaville, the Pool region, the reliability of the vital rail link between Pointe-Noire (the port city and economic capital) and Brazzaville (the administrative capital) has improved considerably, and a concerted effort to improve the train service is underway. 


\section{Cost of Conflicts}

11. As the security situation has improved, the enormity of the destruction left by the last three successive and intense rounds of civil wars has been revealed:

- Key social and economic indicators deteriorated or stagnated in the 1990s, and the external debt burden is heavy (see Table II.1).

- $\quad$ Large parts of the country were affected but the 1993 and 1997 wars led to more intense violence in the capital, Brazzaville, which is home to about 25 to 30 percent of the population (800,000 people).

- $\quad$ The five-month civil war in 1997 inflicted massive destruction on Brazzaville. A large part of the buildings, infrastructure, and productive capital was destroyed and most private property was severely damaged looted, or both. The population suffered substantial casualties, with more than 700,000 people displaced at one point. The cost of the physical damage alone has been estimated at about 37 percent of 1977 GDP.

- $\quad$ The damage inflicted by the 1998-99 conflict, which mainly affected the south of the country (although the area around Pointe-Noire was spared), was estimated at about 75 percent of 1999 GDP.

- In addition to the direct damage of the war, infrastructure suffered considerable damage from the interruption of maintenance. About half of the 17,000-kilometer road network is no longer passable, and most regional capitals no longer have reliable access to major roads. Entire provinces have no access to clean water. Economic agents have lost assets (buildings, livestock, and tools).

- $\quad$ Over 50 percent of the medical structures were ransacked, and educational buildings in the four southernmost provinces suffered considerable damage. Social services are no longer delivered in large parts of the country, particularly in rural areas.

- $\quad$ The World Bank estimates that, at the end of 2001, an estimated 7.2 percent of the Congolese adult population (15-49 years) was living with HIV/AIDS. In PointeNoire, the prevalence rate increased from 10 percent in 1996 to 14 percent in 2000.

- $\quad$ The World Bank estimates that unemployment is affecting more than 50 percent of the active population and that youth are particularly affected: less than 30 percent of those in the 15-to-25-year old bracket have a job, and less than 2 percent are employed in the formal sector. 


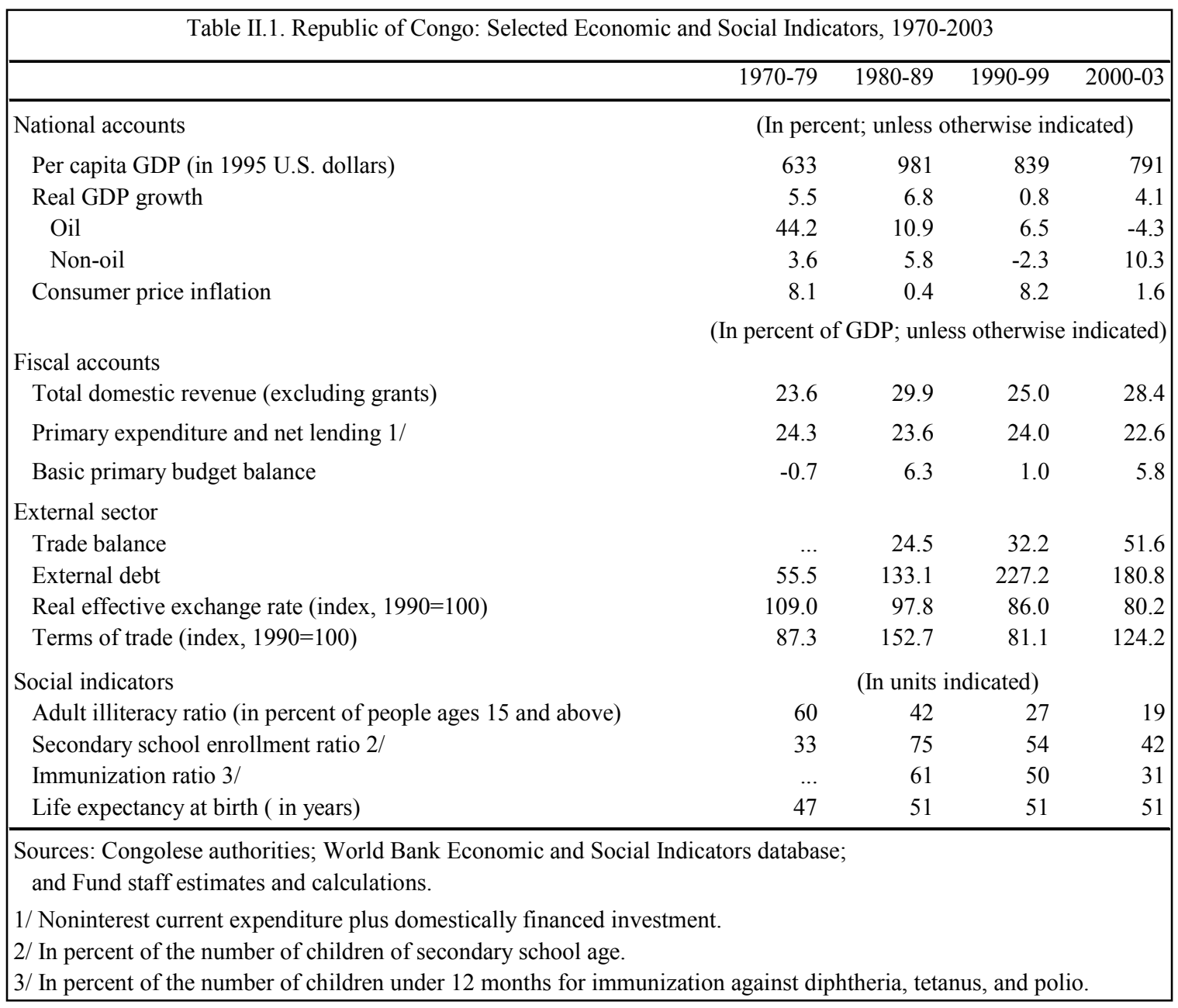




\section{ECONOMiC Performance During 1970-2003 ${ }^{4}$}

12. Per capita output development during 1970-2003 can be divided into three distinct subperiods (Figure III.1 and Table III.1): 1970-84, when output grew almost continuously; 1985-99 when it declined significantly; and 2000-03, when it generally started to recover. ${ }^{5}$ Notwithstanding the recent rise in output, per capita real GDP in 2003 was only about 70 percent of its level in 1984.

13. Since 1986, the Congo has not successfully implemented the six formal and three informal (staff-monitored) programs with the Fund (Box III.1). Key reasons for these results have included: (i) the inherited sluggishness of the planned economy, which has long had a negative impact on the private sector; (ii) the civil wars of the 1990s, which disrupted the economy, weakened institutions, and undermined the rule of law; (iii) the weakness of economic management during the transition period that followed the war; and (iv) insufficient ownership of program implementation.

\section{A. Output Expansion, 1970-84}

14. Per capita real GDP doubled during this period, with three-fourths of the expansion stemming from the non-oil sector and the remainder from a rapidly booming oil output. In view of rising oil revenue, government investment increased by an annual average of 2 percentage points of GDP between 1970-74 and 1975-79. Starting in the second half of the 1970s, two new public institutions concerned with cash crops were set up: the Office for Food Crops (Office des Cultures Vivrières-OCV) and Office for Coffee and Cocao (Office du Café et du Cacao - OCC). In addition, farm producer prices were raised repeatedly. Heavy emphasis was given to schooling, and employment was virtually guaranteed for high school and university graduates either in the civil service or in state enterprises. This resulted in serious overstaffing in the government administration and public enterprises. In view of the large expansion in both capital and current expenditures, there was a significant deterioration in public finances in the second half of the 1970s, compared with the first half.

\footnotetext{
${ }^{4}$ This section was prepared by Dhaneshwar Ghura.

${ }^{5}$ The analysis in this section was primarily derived from an examination of previous Fund staff reports on the Congo.
} 
Figure III.1. Republic of Congo: Macroeconomic Performance, 1970-2003

Per Capita Real GDP

(In thousands of 1990 CFA francs)

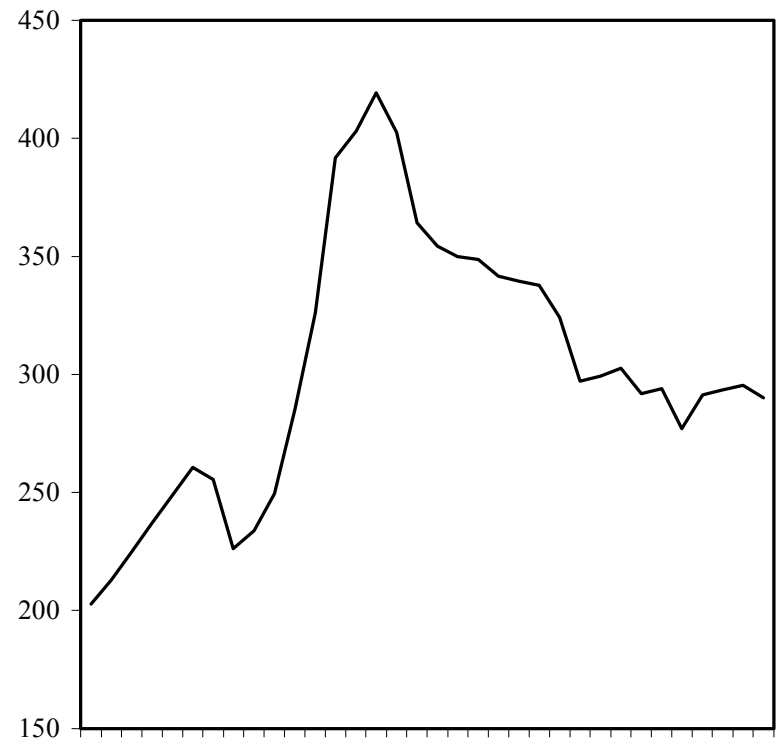

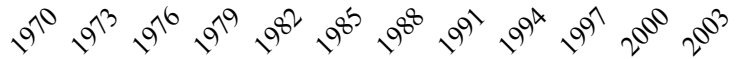

Budgetary Performance

(In percent of GDP)

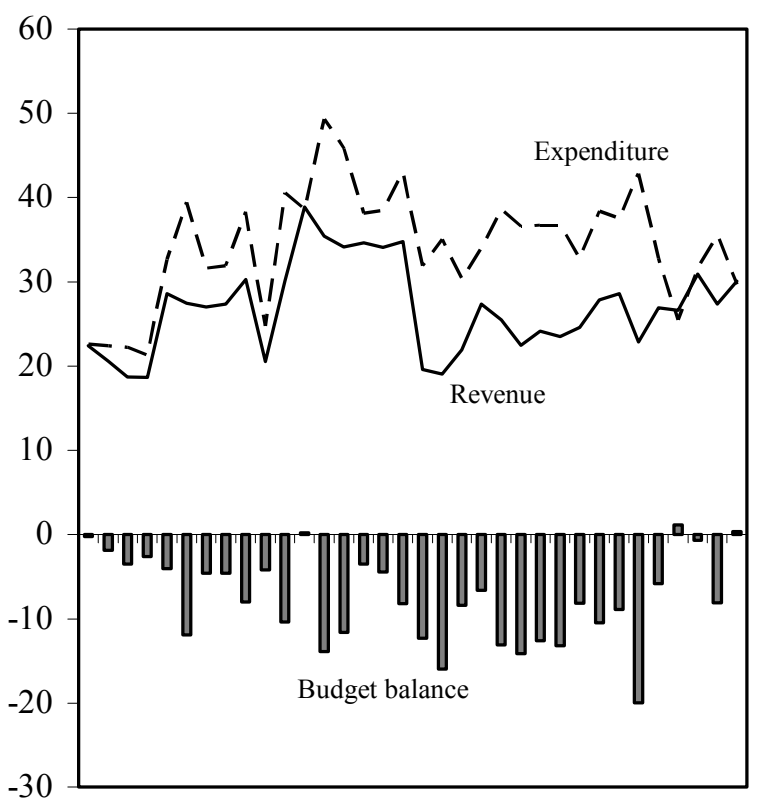

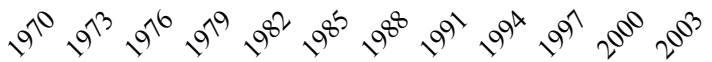

Domestic Investment

(In percent of GDP)

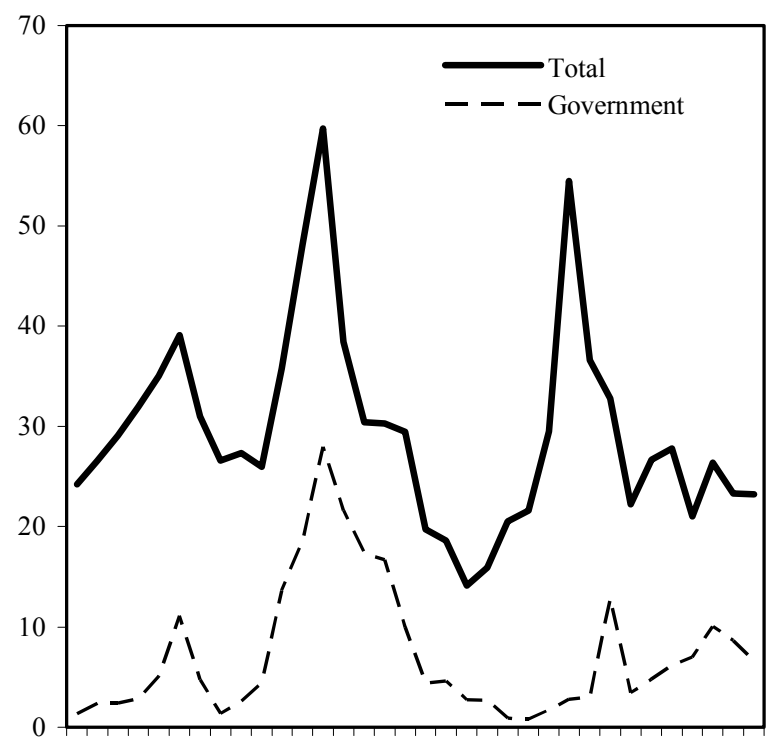

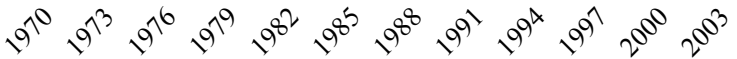

Terms of Trade and Exchange Rate

(Index, 1990=100)

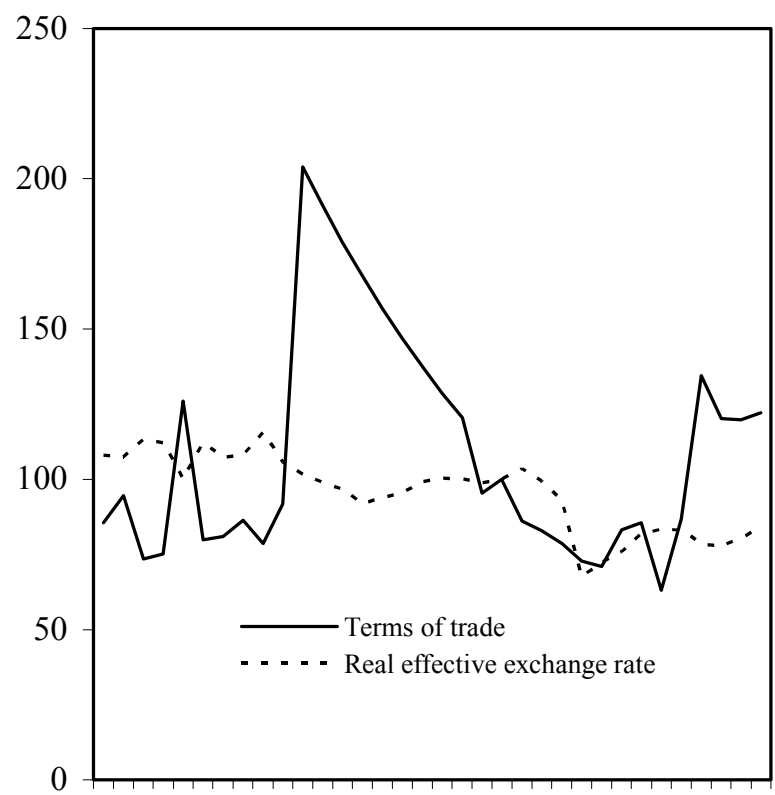

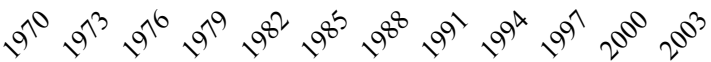

Source: World Development Indicators (World Bank) database; World Economic Outlook (IMF) database; and IMF country reports. 
Table III.1. Republic of Congo: Selected Indicators of Economic Performance, 1970-2003

(Period average, in units indicated)

\begin{tabular}{|c|c|c|c|c|c|c|c|}
\hline & $1970-74$ & $1975-79$ & $1980-84$ & $1985-89$ & $1990-94$ & $1995-99$ & $2000-03$ \\
\hline Real sector & \multicolumn{7}{|c|}{ (Percentage change; unless otherwise indicated) } \\
\hline Per capita GDP (1995 U.S .dollars) & 606.1 & 659.5 & 982.3 & 979.2 & 882.6 & 795.6 & 790.5 \\
\hline Real GDP & 7.8 & 3.2 & 14.3 & -0.7 & -0.1 & 1.7 & 4.1 \\
\hline Oil & 86.5 & 1.9 & 12.5 & 9.3 & 3.8 & 9.1 & -4.3 \\
\hline Non-oil GDP-GDP ratio (1990 constant prices) & 85.9 & 83.3 & 83.3 & 77.6 & 69.5 & 59.3 & 61.7 \\
\hline Oil GDP-GDP ratio (1990 constant prices) & 14.1 & 16.7 & 16.7 & 22.4 & 30.5 & 40.7 & 38.3 \\
\hline Consumer price index & 4.9 & 11.4 & 3.7 & -2.8 & 9.0 & 7.4 & 1.6 \\
\hline Investment-GDP ratio (in percent) & 29.4 & 30.0 & 42.5 & 22.4 & 28.4 & 29.2 & 23.5 \\
\hline Of which: Central government & 2.8 & 4.8 & 19.8 & 7.7 & 1.8 & 6.0 & 8.1 \\
\hline Population & 2.7 & 2.9 & 2.9 & 3.0 & 3.1 & 3.1 & 2.8 \\
\hline Government budget & \multicolumn{7}{|c|}{ (In percent of GDP; unless otherwise indicated) } \\
\hline Total revenue and grants & 21.8 & 26.5 & 34.6 & 25.9 & 24.6 & 26.2 & 28.7 \\
\hline Total domestic revenue & 21.4 & 25.8 & 34.1 & 25.8 & 24.3 & 25.7 & 28.4 \\
\hline Oil revenue & 2.7 & 7.6 & 20.9 & 13.0 & 13.3 & 16.3 & 20.2 \\
\hline Non-oil revenue & 18.7 & 18.2 & 13.2 & 12.8 & 10.9 & 9.4 & 8.2 \\
\hline Grants & 0.4 & 0.8 & 0.5 & 0.1 & 0.3 & 0.4 & 0.3 \\
\hline Total expenditure and net lending & 24.2 & 33.2 & 42.5 & 35.8 & 36.5 & 36.9 & 30.6 \\
\hline Primary expenditure and net lending 1/ & 21.2 & 27.3 & 24.3 & 22.9 & 26.4 & 21.6 & 22.6 \\
\hline Current expenditure & 20.5 & 25.9 & 19.2 & 20.4 & 24.7 & 17.8 & 15.3 \\
\hline Domestically-financed investment & 0.7 & 1.2 & 5.0 & 1.9 & 0.9 & 3.8 & 7.3 \\
\hline Net lending & 0.0 & 0.2 & 0.1 & 0.6 & 0.8 & 0.0 & 0.0 \\
\hline Interest due & 0.9 & 2.2 & 3.3 & 7.1 & 9.3 & 13.1 & 7.1 \\
\hline Externally-financed investment & 2.1 & 3.6 & 14.9 & 5.8 & 0.8 & 2.2 & 0.8 \\
\hline Basic primary budget balance 2 / & 0.1 & -1.6 & 9.8 & 2.9 & -2.2 & 4.2 & 5.8 \\
\hline \multicolumn{8}{|l|}{ External sector } \\
\hline Current account balance & $\ldots$ & $\ldots$ & $\ldots$ & $\ldots$ & $\ldots$ & -24.5 & 0.9 \\
\hline Trade balance & $\ldots$ & $\ldots$ & 23.3 & 25.6 & 24.3 & 40.1 & 51.6 \\
\hline Exports of goods & $\ldots$ & $\ldots$ & 30.0 & 38.9 & 45.3 & 66.7 & 74.1 \\
\hline Imports of goods & $\cdots$ & $\ldots$ & 6.7 & 13.3 & 20.9 & 26.6 & 22.4 \\
\hline Services balance & $\cdots$ & $\ldots$ & $\ldots$ & $\ldots$ & $\ldots$ & -31.7 & -23.1 \\
\hline Income & $\ldots$ & $\ldots$ & $\ldots$ & $\ldots$ & $\ldots$ & -33.5 & -27.8 \\
\hline Transfers & $\ldots$ & $\ldots$ & 0.7 & 1.1 & 0.7 & 0.6 & 0.3 \\
\hline External debt & 41.0 & 70.0 & 89.6 & 176.6 & 217.5 & 236.9 & 180.8 \\
\hline Volume of exports of goods and services (in percent change) & 8.7 & 5.6 & 13.4 & 2.2 & 1.4 & 7.2 & 2.4 \\
\hline Volume of imports of goods and services (in percent change) & 2.5 & -5.3 & 22.0 & -9.3 & 36.4 & 0.4 & 13.8 \\
\hline Terms of trade (index, 1990=100) & 91.0 & 83.5 & 179.6 & 125.8 & 84.1 & 78.0 & 124.2 \\
\hline Real effective exchange rate (index, 1990=100) & 108.3 & 109.8 & 96.7 & 98.8 & 92.7 & 79.3 & 80.2 \\
\hline Oil price $(\mathrm{US} \$ /$ barrel) & 5.2 & 17.1 & 33.3 & 18.7 & 19.2 & 17.4 & 26.6 \\
\hline \multicolumn{8}{|l|}{ Memorandum item: } \\
\hline Non-oil revenue (in percent of nonoil GDP) & $\ldots$ & $\ldots$ & 15.9 & 16.4 & 14.9 & 16.4 & 18.7 \\
\hline
\end{tabular}

Sources: Congolese authorities.

1/ Noninterest current expenditure plus domestically financed investment.

2/ Domestic revenue (excluding grants) minus primary current expenditure and net lending. 
Box III.1. Republic of Congo: Performance Under Fund Programs, 1986-2003

\begin{tabular}{|c|c|c|c|c|}
\hline Program & Period covered & $\begin{array}{r}\text { Amount } \\
\text { approved } \\
\text { (SDR million) }\end{array}$ & $\begin{array}{r}\text { Amount } \\
\text { drawn }\end{array}$ & Implementation status \\
\hline $\begin{array}{l}\text { Staff-Monitored } \\
\text { Program }\end{array}$ & Jan.-Sept. 2003 & N/A & & $\begin{array}{l}\text { Overall weak performance, despite some } \\
\text { achievements. Unbudgeted use of windfall oil } \\
\text { revenue and significant shortfall in nonoil revenue. } \\
\text { Mixed record on structural reform implementation, } \\
\text { but efforts made to improve oil sector transparency } \\
\text { and public finance management. }\end{array}$ \\
\hline $\begin{array}{l}\text { Staff-Monitored } \\
\text { Program }\end{array}$ & April-Dec. 2002 & N/A & & $\begin{array}{l}\text { Overall weak performance. Nonoil revenue shortfall, } \\
\text { and higher-than-programmed current expenditures. } \\
\text { Weaknesses in structural reform implementation. }\end{array}$ \\
\hline \multirow{3}{*}{$\begin{array}{l}\text { Staff-Monitored } \\
\text { Program }\end{array}$} & & & & $\begin{array}{l}\text { Overall weak performance. Deviations in fiscal } \\
\text { targets and borrowing from the banking system. }\end{array}$ \\
\hline & June-Dec. 2001 & N/A & & Mixed record on structural reform implementation. \\
\hline & & & & $\begin{array}{l}\text { Significant slippages registered in the quantitative } \\
\text { targets. }\end{array}$ \\
\hline $\begin{array}{l}\text { Emergency Post } \\
\text { Conflict Assistance }\end{array}$ & $\begin{array}{l}\text { Approved in } \\
\text { Nov. } 2000\end{array}$ & 10.6 & N/A & $\begin{array}{l}\text { Program implementation broadly satisfactory } \\
\text { through September 1998, but preparations of a } \\
\text { successor new arrangement under the ESAF were }\end{array}$ \\
\hline $\begin{array}{l}\text { Emergency Post } \\
\text { Conflict Assistance }\end{array}$ & $\begin{array}{r}\text { Approved in } \\
\text { July } 1998\end{array}$ & 7.25 & $\mathrm{~N} / \mathrm{A}$ & $\begin{array}{l}\text { derailed due to a renewed outbreak of civil unrest in } \\
\text { late } 1998 .\end{array}$ \\
\hline $\begin{array}{l}\text { Enhanced Structural } \\
\text { Adjustment Facility }\end{array}$ & $6 / 96-6 / 99$ & 69.5 & 13.9 & $\begin{array}{l}\text { Overall performance under the first annual } \\
\text { arrangement was mixed owing to lapses in fiscal } \\
\text { discipline and insufficient resolve to implement } \\
\text { structural reform. The ESAF midterm review was } \\
\text { interrupted in June 1997, following the eruption of } \\
\text { civil war. The arrangement remained suspended until } \\
\text { its expiration. }\end{array}$ \\
\hline & & & & $\begin{array}{l}\text { The program veered off-track shortly after it was } \\
\text { launched in the context of continued sociopolitical } \\
\text { tensions. }\end{array}$ \\
\hline $\begin{array}{l}\text { Stand-By } \\
\text { Arrangement }\end{array}$ & $5 / 94-5 / 95$ & 23.2 & 12.5 & $\begin{array}{l}\text { Economic policies diverged from the program } \\
\text { objectives as a result of the sudden domestic } \\
\text { agitation for political change. Owing to unrest, the } \\
\text { first review could not be conducted. }\end{array}$ \\
\hline $\begin{array}{l}\text { Stand-By } \\
\text { Arrangement }\end{array}$ & $8 / 90-5 / 92$ & 28.0 & 4.0 & $\begin{array}{l}\text { The program veered off-track and could not be } \\
\text { brought back on track on account of excess use of } \\
\text { bank credit by the government and unprogrammed } \\
\text { accumulation of external payments arrears. } \\
\text { Structural measures in the areas of pricing, } \\
\text { marketing, public enterprise and recruitment policies }\end{array}$ \\
\hline $\begin{array}{l}\text { Stand-By } \\
\text { Arrangement }\end{array}$ & $8 / 86-4 / 88$ & 22.4 & 9.5 & were satisfactorily implemented. \\
\hline
\end{tabular}


15. Oil prices rose from an annual average of US\$17 per barrel during 1975-79 to about US\$33 per barrel in the first half of the 1980s. In view of the rapidly rising oil revenues, the Congolese authorities adopted in 1981 an ambitious Five-Year Economic and Social Development Plan, underlying which was an overly expansionary fiscal policy path. This plan gave priority to improving basic infrastructure (roads, railroads, and waterways) and to rehabilitating state enterprises. Government investment rose by an annual average of 15 percentage points between the second half of the 1970s and the first half of the 1980s. Even though current expenditure was curtailed, the domestic financial imbalances, which had widened in the second half of the 1970s, continued to deteriorate in the first half of the 1980s. In addition, the country's external indebtedness, which had been growing rapidly in the 1970s and early 1980s to finance domestic investment projects, doubled between 1980-84 and 1985-89.

\section{B. Output Collapse, 1985-99}

16. The rapid rise in the public sector during the oil boom years of the early 1980 s, including in the form of massive public employment creation, partly provided the seeds for the subsequent long decline in output. The oil bonanza came to an end in the second half of the 1980 s, when oil prices declined to an annual average of about US $\$ 181 / 2$ per barrel during 1985-89 (from an annual average of about US $\$ 33$ per barrel during 1980-84). In view of the associated significant decline in oil revenues, the government took internal adjustment measures, including in the context of a 20-month Stand-By Arrangement launched in August 1986. The list of products ${ }^{6}$ subject to price regulation was reduced, with a view to eliminating subsidies. In addition, the export monopoly of the OCC and the marketing monopoly of the OCV were abolished. Furthermore, the government undertook measures to strengthen public enterprise management and efficiency and liquidate financially unviable enterprises. However, the process of public enterprise restructuring required the government to assume a substantial amount of their debts. Notwithstanding the budgetary constraints, the government continued to raise agricultural producer prices for cocoa, coffee, tobacco, potatoes, and rice.

17. The Congolese policy response to the collapse in the terms of trade in the second half of the 1980s was slow and limited. While current and capital expenditures were lowered, they were not cut back in line with reduced resource availability. The budgetary deficit widened further during 1985-89 from an already large fiscal imbalance during 1980-84. The significant cut in government expenditures, especially capital outlays, during 1985-89 had a deflationary impact on the economy. The non-oil real GDP and the consumer price index each declined by about 3 percent on average per annum during 1984-89. The economic and financial imbalances were exacerbated by the weak performance of the large public enterprise sector, which, even after receiving substantial government transfers and

\footnotetext{
${ }^{6}$ The list included flour, bread, rice, sugar, salt, transportation, electricity, water, and petroleum products.
} 
exemptions, experienced continuing losses, which led the government to take over the debtservice obligations of some enterprises. The disappointing performance of the public enterprises was due to rapidly growing personnel costs, inflexible pricing policies that did not reflect production costs, and management problems. The 1986 Stand-By arrangement went off track because of the deviations of macroeconomic outcomes from program targets (e.g., net bank credit to the government and external arrears), although structural measures in the areas of pricing, marketing, public enterprise and recruitment policies were satisfactorily implemented.

18. In order to reverse the declining trends in output, the government continued its attempt in the early 1990s to jump-start the economy-including in the context of a 21-month Stand-By arrangement adopted in August 1990-following a strategy that was based solely on internal adjustment measures, as had been done in the second half of the 1980s. This approach consisted mainly of maintaining the fixed common peg, lowering the fiscal deficit through increases in tax rates and cuts in the wage bill, and restoring external competitiveness by reducing domestic costs and restructuring public enterprises. As a result of a sudden upheaval and agitation for political change, economic policies diverged widely from those underlying the 2000 Stand-By arrangement, and the first review under the program could not be undertaken.

19. Overall, the policy response during the period 1986-93 to the worsened external environment was inadequate, relying mainly on cuts in government investment spending and limited structural reforms. As a result, economic activity stagnated, public sector and external imbalances widened markedly, and the external public debt and debt-service burdens grew to unsustainable levels. In addition, large domestic and external payment arrears were accumulated. The CFA franc became overvalued in the late 1990s because, even though the terms of trade had declined almost secularly between 1980-84 and 1990-94, the real effective exchange rate remained virtually unchanged.

20. Given the magnitude of the macroeconomic imbalances in the late 1980s and early 1990s, it became clear by 1993 that strategies based solely on internal adjustments would be insufficient to put the economy back on a sustainable recovery track. The internal adjustment strategy was insufficient to restore external competitiveness, as nominal domestic prices (including wages and producer prices) showed considerable downward rigidity. The adjustment strategy was broadened in January 1994 with the 50 percent devaluation of the CFA franc. In addition, the government adopted a 12-month Stand-By arrangement in April 1994. Against the background of continued sociopolitical tensions and security concerns, the Congo's economic performance under the Stand-By arrangement fell short of program expectation, owing to policy slippages, weak management capacity, and disruptions of railroad transportation.

21. With a view to setting the economy on a path of sustainable growth and poverty reduction, the authorities adopted a three-year program under the Enhanced Structural Adjustment Facility (ESAF) in June 1996. The program focused on (i) raising the primary budget surplus, so as to reduce the unsustainably heavy external debt and debt-service 
burdens; (ii) increasing government outlays on education, health, and public investment, thanks to further savings on the civil service wage bill; and (iii) stepping-up the implementation of a broad range of structural reforms in order to restore confidence in the banking system, enhance financial intermediation, reduce the role of state monopolies, and improve the quality and reduce the cost of public services. Overall performance under the first annual arrangement was mixed, owing to lapses in fiscal discipline and insufficient resolve to implement structural reform. The ESAF midterm review was interrupted in June 1997, following the eruption of civil war, and the arrangement remained suspended until its expiration.

22. Following the five-month civil war in 1997 and the ensuing reconciliation process, the IMF provided technical and financial assistance in the form of an emergency post conflict Assistance (EPCA) approved in July 1998. A key priority under the EPCA was to create the conditions to either reactivate the existing ESAF arrangement or to launch a new three-year ESAF-supported program. Program implementation was broadly satisfactory through September 1998, but preparations for a successor new under the ESAF arrangement were derailed owing to a renewed outbreak of civil unrest in late 1998.

23. Following the 1998/99 conflict, a cease-fire agreement was signed in late 1999, which provided for a national dialogue, demilitarization of political parties, and the reorganization of the army, including the readmission of rebel units into the security forces. The IMF provided technical and financial assistance in the form of an EPCA approved in November 2000. The EPCA was geared toward strengthening the country's administrative capacity and improving the macroeconomic framework, with a view to launching a successor mediumterm program for sustainable growth and poverty reduction. Nonetheless, significant slippages were encountered on key quantitative targets.

\section{Recent Output Recovery, 2000-03}

24. Recent developments on the security front are encouraging, against the background of recurrent conflicts in the 1990s (see Section II). The onset of peace in 1999-2000 boosted economic activity and contributed to macroeconomic stability during 2000-03 (Figure III.2). Non-oil real GDP increased by about 10 percent per annum on average during 2000-03. Consumer price inflation decelerated significantly, helped by more reliable supply line from Pointe-Noire to Brazzaville and a strengthening of the euro. The basic primary fiscal balance improved between 1995-99 and 2000-03.

25. Nonetheless, while the post-conflict period ushered in by the 1999 cease-fire agreement has been conducive to improved economic performance and the installation of democratic institutions, it has thus far not been accompanied by the strict implementation of economic programs. Over this period, the program launched in November 2000 under the EPCA and three subsequent staff-monitored programs (SMPs) were not successful at laying the foundations for moving to possible support under the Poverty Reduction and Growth Facility (PRGF). Program implementation has been weak both on the quantitative and structural fronts (see Box III.1). However, the combination of a steadily improving security 
situation and some encouraging results under the 2003 SMP have generated cautious optimism that a virtuous circle of political stability and economic reform has been set in motion. While overall performance under the 2003 SMP was weak, the authorities took steps, especially later in 2003, to enhance transparency and governance in the oil sector and to strengthen public finance management (see Box III.2 and Section IV).

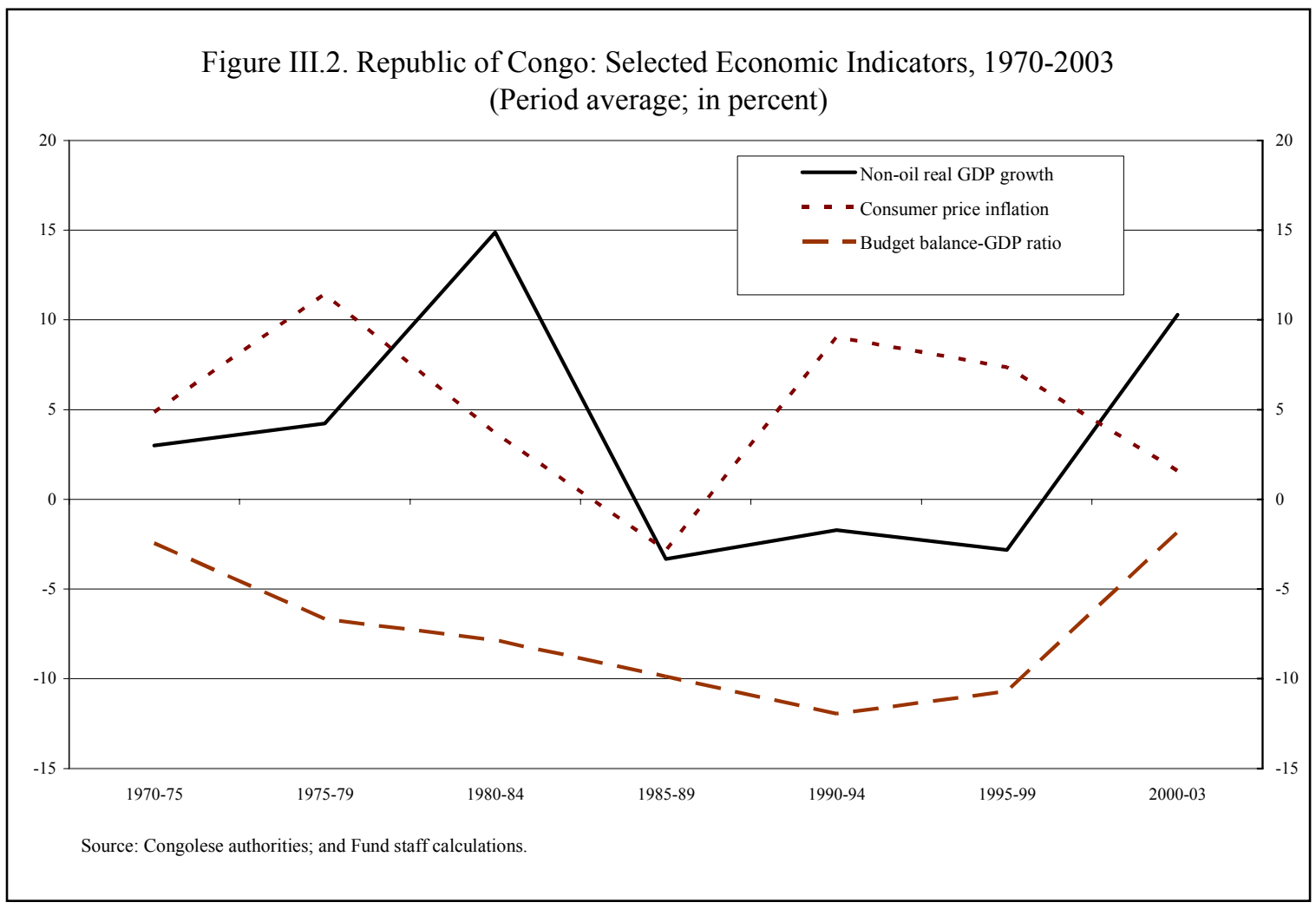

\section{Observations and Evaluation}

26. To a large extent, government investment was pro-cyclical, varying in tandem with oil price movements in the international oil market (Figure III.3). Non-oil real GDP growth, in turn, was highly correlated with government investment-GDP ratio (with a correlation coefficient of about 66 percent during 1975-2003). ${ }^{7}$ Thus, the boom-bust cycle of output appears to have been directly or indirectly linked to oil price movements.

27. The three successive rounds of conflicts in the 1990s followed the economic crisis of the second half of the 1980s. The origin of the economic crisis appears to have been the

\footnotetext{
${ }^{7}$ Using five-year moving average data during 1975-2003, the correlation coefficient between government investment-GDP ratio and international oil price is 77 percent.
} 
inadequate policy response to the significant decline in oil prices and the sharp drop in oil revenues, government investment, economic growth. As a result, the budget deficit ballooned to unsustainable levels and the burden of external debt became quite onerous. In a nutshell, these conflicts were preceded by the pre-conditions that have been identified in the recent empirical literature on conflicts (see Section V).

28. As noted in Section II, the conflicts in the 1990s created a major setback for the economic and social progress that had been registered in the 1970s and 1980s. In retrospect, the boom in the 1980s in output growth, investment, and indicators of human capital development - financed by rising oil revenues and external debt — was unsustainable. A policy framework, underpinned by a transparent fiscal rule for the judicious use of oil resources, could have led to a smoother consumption- investment profile and contributed to avoiding the significant output collapse and the conflicts.

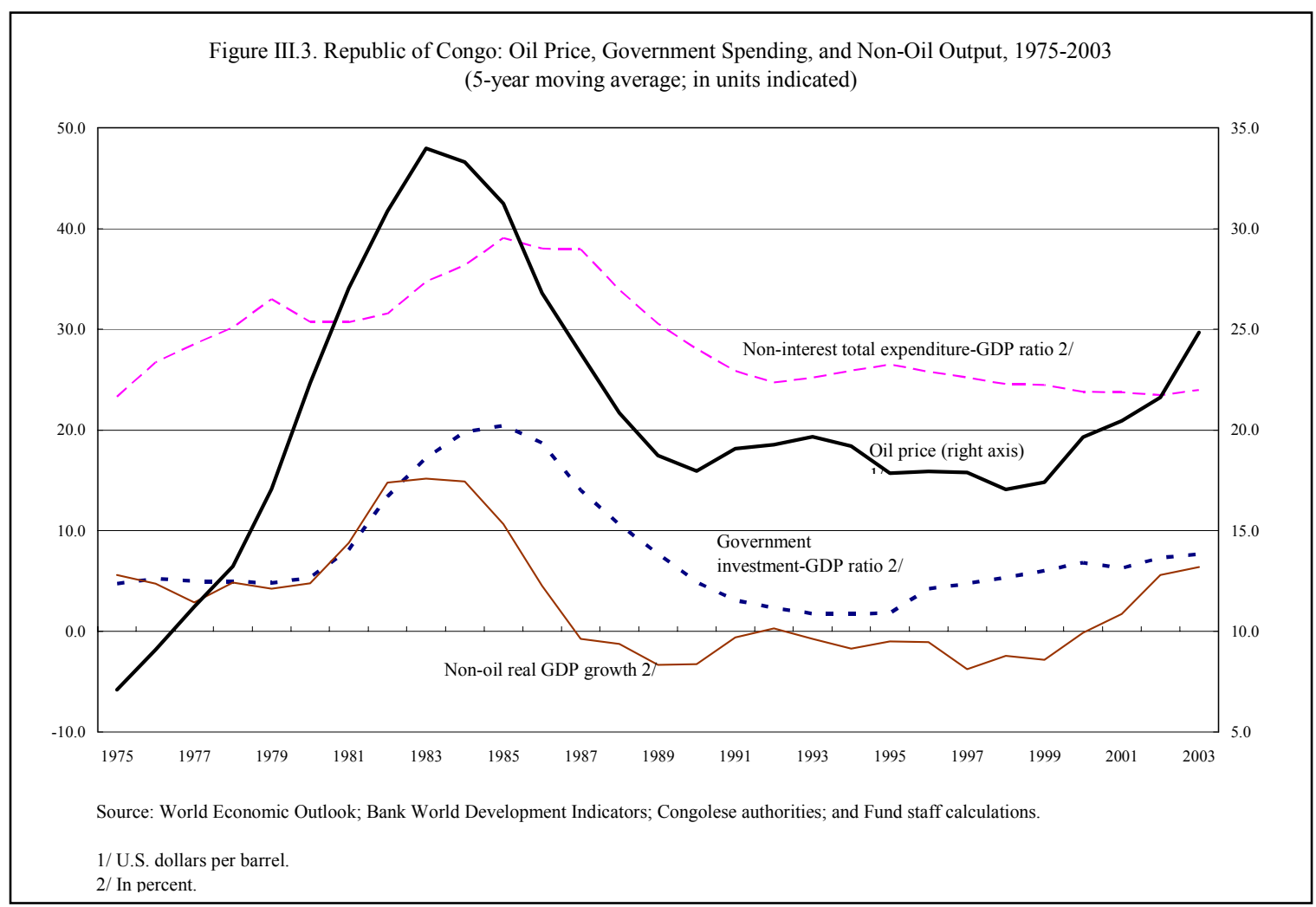




\section{Box III.2. Republic of Congo: Program Implementation in 2003}

Overall performance under the 2003 SMP (covering January-September 2003) was weak:

- Fiscal performance was weak, as the primary fiscal surplus fell short of the program target by some CFAF 57 billion (equivalent to 2.8 percent of annual GDP). The main reasons included (i) a significant shortfall in non-oil revenue, (ii) the retention of tax obligations by the national oil company (SNPC), and (iii) unprogrammed expenditures. Additionally, exceptional oil receipts ${ }^{1}$ and unprogrammed oil bonus and dividend receipts were effectively used to clear unprogrammed internal arrears.

- On the structural front, performance was mixed. The audit of the SNPC for 1999-2001 was completed, efforts were made to centralize government revenues, no new oil-collateralized debt was contracted, and initiatives were launched to publish oil sector data. Nonetheless, not all nonreschedulable debt service was paid, the privatization of the remaining publicly owned bank (CAIC) was not completed, and the end-September 2003 measures on oil sector transparency were not implemented.

The authorities set quantitative and structural targets in the last quarter of 2003, with a view to stabilizing the fiscal slippages registered under the SMP and further enhancing transparency and governance in the oil sector:

- On the fiscal front, the basic primary budget balance objective (which had been revised downward) was met. Nonetheless, unprogrammed outlays were made to clear pension arrears and finance structural reform costs.

- On the structural front, a significant step was taken to enhance transparency in the oil sector with the completion of the certification, by an external auditor, of government oil revenue for the period January-September 2003. Measures in the fiscal area included (i) the appointment of new directors in the General Directorates of Budget, Customs, and Taxes, as well as at the General Inspectorate of Finance, in order to reinvigorate the revenue departments and strengthen control; (ii) the signing of an agreement by the government, SNPC, and the oil refinery (CORAF), to have the latter pay for its purchase of government crude oil; and (iii) the production of the 2000 budget review law (Loi de règlement).

${ }^{1}$ These receipts resulted from the settlement of a legal dispute with a private oil company. 


\section{Recent Reforms in Public Finance Management ${ }^{8}$}

29. Since the last quarter of 2002, the Republic of Congo (hereafter "the Congo") has implemented a number of structural measures in the fiscal area, with assistance from the Fund's Fiscal Affairs Department (FAD) and other donors. These efforts are encouraging, against the background of relatively weak human and technical capacity and in view of constrained resources. This section focuses on three key areas of public finance management: (i) the budget framework, (ii) revenue mobilization, and (iii) expenditure and cash management. Following a brief summary of institutional practices and procedures, the discussion identifies the reform measures recently launched to address identified weaknesses. The section concludes by identifying key reform measures that could be undertaken in the period ahead.

\section{A. The Budget Framework}

30. The institutional budget framework has been identified as weak, reflecting the country's overall weakened administration after years of armed conflicts of the 1990s. As highlighted in 2001 by an FAD mission, ${ }^{9}$ the budget calendar has often been observed with delays. On a technical level, preliminary tax and customs revenue forecasts were infrequently updated, and expenditure costing (in particular for utilities) was inadequate. The capital budgeting has been identified as cumbersome with several entities intervening in budget preparation and execution (Ministry of Finance, Economy, and Budget; and Ministry of Planning; and Debt Management Agency). Certain steps in the internal budgetary controls are redundant (the roles of the Financial controller and the Director of Budget in the control process often overlap) and inefficient (focusing on bureaucratic process rather than the objectives sought); inadequate training of controllers and insufficient material equipment have been identified as key technical problems.

31. Recent efforts have focused on improving the degree of centralization of revenues and expenditures within the budget framework, and to eliminate past practices of having the oil companies undertake government spending outside the budget framework. Additionally, the following complementary measures have been undertaken:

- $\quad$ The draft 2000 budget review law (Loi de règlement) was prepared in 2003.

- Delays in preparing the budget and sending it to parliament have been progressively reduced, and the 2004 budget was adopted with only a slight delay.

\footnotetext{
${ }^{8}$ This section was prepared by Yaya Moussa.

${ }^{9}$ International Monetary Fund, 2002, "Republic of Congo: Revenue Administration and Expenditure Management", by Dominique Bouley, Yaya Moussa, Annette Tricoire, and Ben Brik (Washington: IMF, April 2002).
} 
- $\quad$ More transparency and coherence is being introduced into the budget preparation process. The 2003 and 2004 budgets were discussed in parliament. Regular meetings on budget preparation among the General Directorates of the Budget (Ministry of Finance) and Planning (Ministry of Planning) have helped to improve consistency between the current and the capital budgets in both the data and policy orientation.

- The quality of non-oil revenue forecasts have been improved, especially in the 2004 budget framework, by explicitly taking into account underlying macroeconomic trends.

\section{B. Revenue Mobilization}

32. The effectiveness of tax and customs administrations is constrained by weak human capacity, insufficient computerization, limited circulation of information, and poor guidance from departmental management. More specifically, weak administrative capacity has impeded effective management of the value added tax (VAT), and the two large-taxpayers units (Brazzaville and Pointe-Noire) do not manage all taxes pertaining to large corporations.

33. The following actions have been recently launched in this area:

- $\quad$ Since 2003, oil revenues are being certified on a regular basis by an audit firm of international reputation.

- $\quad$ Coverage of the territory by tax and customs administration is being reinforced through the establishment of more provincial offices.

- Renegotiation of tax holidays granted to a number of corporations in the oil and forestry sectors has been launched.

- Operational audits of the General Directorates of Tax and Customs were launched, with a view to using their recommendations to enhance the management of these revenue-collecting departments.

- $\quad$ As mentioned earlier, some progress has been achieved in the centralization of oil revenues at the level of the treasury. Petty revenues (e.g., small levies and fines) are more systematically transferred from various agencies to the treasury account.

- A process of computerization of the systems at the General Directorates of Tax and Customs has been launched, with assistance from the World Bank.

- The use of a single taxpayer identification number (NIU), which seeks to improve the tracking of taxpayers and limit tax evasion, is being introduced. 


\section{Expenditure and Cash Management}

34. The treasury system remains relatively weak. Substantial weaknesses in the accounting system, reporting capacity, and cash management effectively hamper data quality, restrict oversight, and constrain analysis. The tracking of expenditures at different phases of the spending circuit (commitment, validation, payment orders and payments) is insufficient, leading to weak monitoring of government domestic arrears. The control of the delivery of goods and services ordered (validation phase of the spending circuit) is often inadequate. Furthermore, in the absence of comprehensive government accounts, the impact of the newly established Court of Accounts would be severely limited.

35. Recent efforts in the area of expenditure and cash management include the following:

- The authorities have refrained from contracting new oil-collateralized debt.

- $\quad$ The use of exceptional spending procedures (paiement par anticipation) has been progressively reduced.

- A process aimed at unification and tighter monitoring of human resource management files has been launched. Procedures to strengthen the monitoring of benefit payments are being introduced.

- A number of the directors at the Ministry of Finance have been replaced in order to raise technical capacity and strengthen management.

- A preliminary consolidated treasury balance was prepared for December 2003, and January and February 2004. Efforts are under way to improve the degree of comprehensiveness and consistency of the report.

- $\quad$ To enhance the control of payment orders, the General Directorate of Finance Inspection has begun to work more closely with the Financial Controller to better verify the delivery of goods and services. This effort should improve the quality and timeliness of data on expenditures and payment arrears.

- A functional classification module in the budget nomenclature (current expenditure component) was introduced, with technical assistance from FAD.

- $\quad$ The relationship between the state, the national oil company (SNPC) and the national refinery (CORAF) is being formalized in order to make budgetary transfers more transparent and to limit the fiscal impact.

\section{Future Steps}

36. To complement the ongoing efforts, the areas of public expenditure management and non-oil revenue mobilization could be strengthened as follows: 
- In public expenditure, there is a need to improve the: (i) comprehensiveness of the budgetary data coverage and frequency of dissemination; (ii) budget process, including compliance with the budget calendar and laws; (iii) budget nomenclature, by extending a functional classification to investment expenditures in order to better track priority spending; (iv) tracking of outlays in the expenditure circuit (commitment, validation, payment order, and actual payment); and (v) internal control, including by streamlining redundancies.

- $\quad$ Regarding non-oil revenue mobilization, reforms will need to focus on:

(i) eliminating ad hoc exemptions; (ii) reinforcing the single Division of Large Taxpayers and entrusting it with the assessment and recovery of all tax liabilities for this group of taxpayers; (iii) accelerating the implementation of the single taxpayer identification system at the customs, tax department, and treasury; (iv) fully implementing the SYDONIA computer system at customs; and (v) completing a computer link between the revenue departments in Pointe-Noire and Brazzaville. 


\section{Constraints to Economic Growth ANd Poverty Reduction ${ }^{10}$}

37. This section attempts to shed light on the constraints on growth by comparing economic and social performance of the Congo with that of comparable regions and countries. It uses results from the existing empirical literature on growth, conflicts, and poverty reduction to provide a perspective on the Congo's performance. Following two decades of above-average performance, per capita real GDP growth declined in the 1990s, following the conflicts (Figures V.1 and V.2). In relation to other comparator groups of countries, the following characteristics appear to constitute the key constraints on growth and poverty reduction in the Congo (see also Tables IV.1 and IV.2 at the end of this Section):

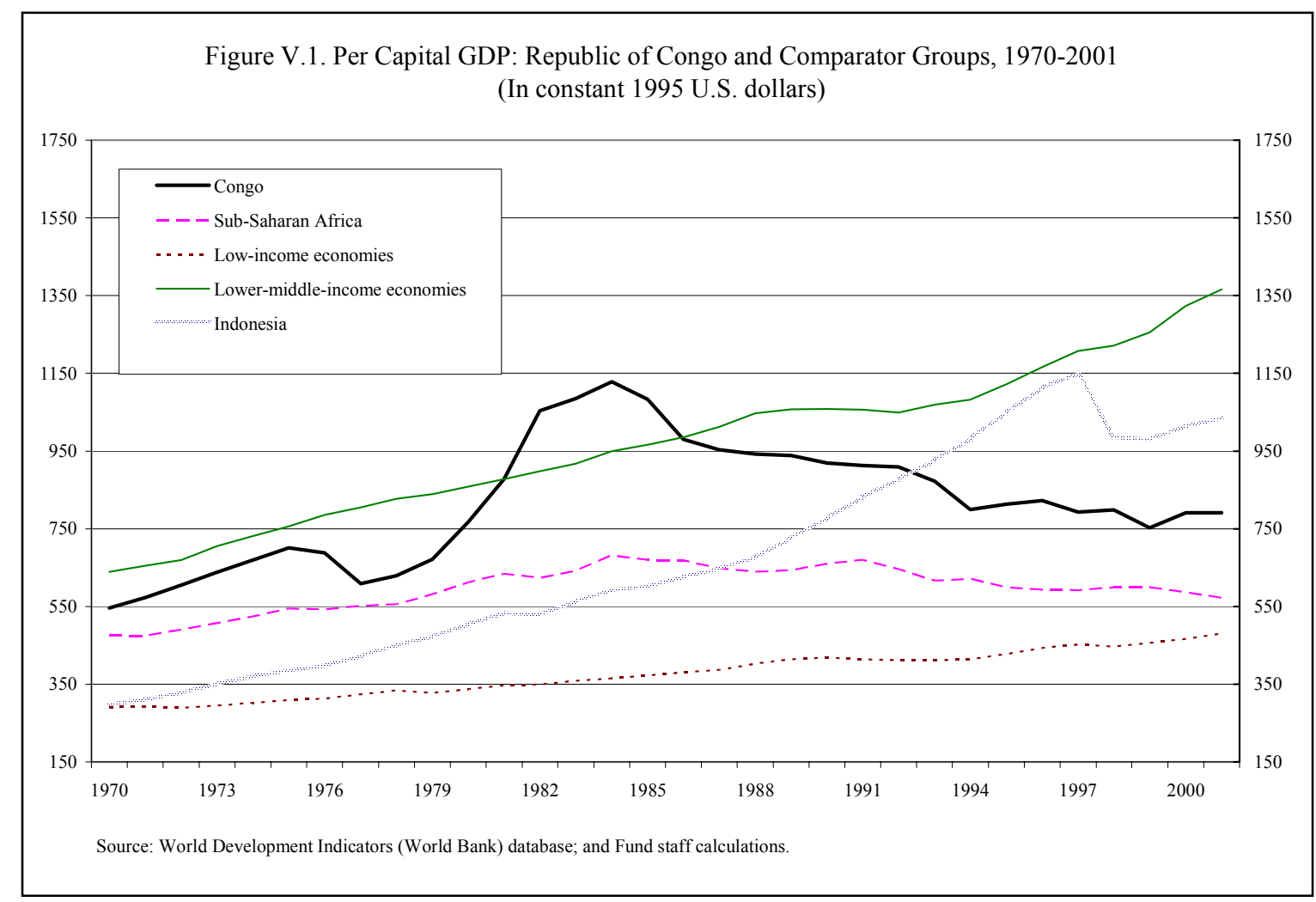

38. Higher dependence on natural resources (Figure V.3). The Congo's dependence on oil rose over time and remained high, in contrast with the experience of Indonesia, where dependence on oil declined significantly in the 1990s and was accompanied by fairly robust per capita real GDP growth. It is now well documented in the empirical literature that abundant natural resources retard economic growth through political economy effects (e.g., Tornell and Lane, 1999) and increases corruption (Mauro, 1995; and Leite and Weidmann, 1999). It is commonly understood that a primary channel of transmission from natural

${ }^{10}$ This section was prepared by Dhaneshwar Ghura and Carlos Leite. 
resources to poor economic performance is the significant amount of time that policymakers spend on maximizing the associated rents from these resources for themselves and their associates. By implication, it also means that there may be intense competition by those close to power to access these scarce resources for personal and political gains. Collier and Hoeffler (2002) have shown that natural resources considerably increase the chances of civil conflict since the available rents can be used to finance rebellions. They estimate that countries with natural resources have a much larger probability of experiencing conflicts than those that do not. Furthermore, the paper by Ghura, Leite, and Tsangarides (2002) has shown that there exists a strong inverse relationship between dependence on natural resources and the income of the poor.

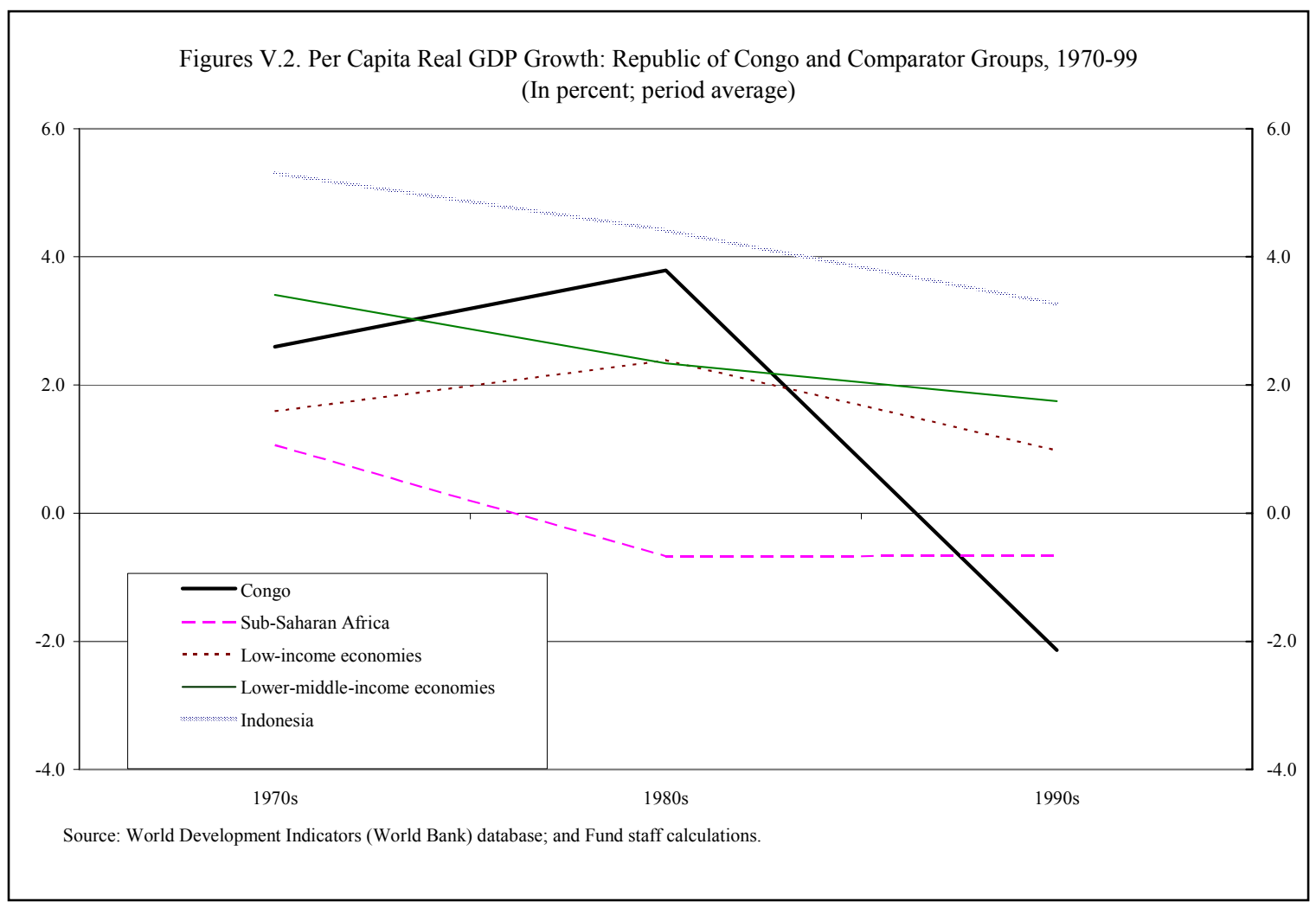

39. Larger government size (Figure V.4). The legacy of a centrally-planned economy during 1964-90 left the Congo with a larger-than-average government size (as measured by the government consumption-GDP ratio). The adverse impact of a large government on economic growth can occur through a number of channels, including the inefficient allocation of scare resources, the crowding out of the private sector, and the existence (or expectation by economic agents) of higher taxes. Empirical studies have shown that economic growth is inversely related to government size (see, for example, Barro, 1989, Grier and Tullock, 1989, and Ghura, 1995). In addition, the paper by Ghura, Leite, and Tsangarides (2002) has shown that there exists a strong negative relationship between government size and the income of the poor. 
Figure V.3. Natural Resource Dependence: Republic of Congo and Comparator Groups, 1970-99 (Fuel exports in percent of merchandise exports; period average)

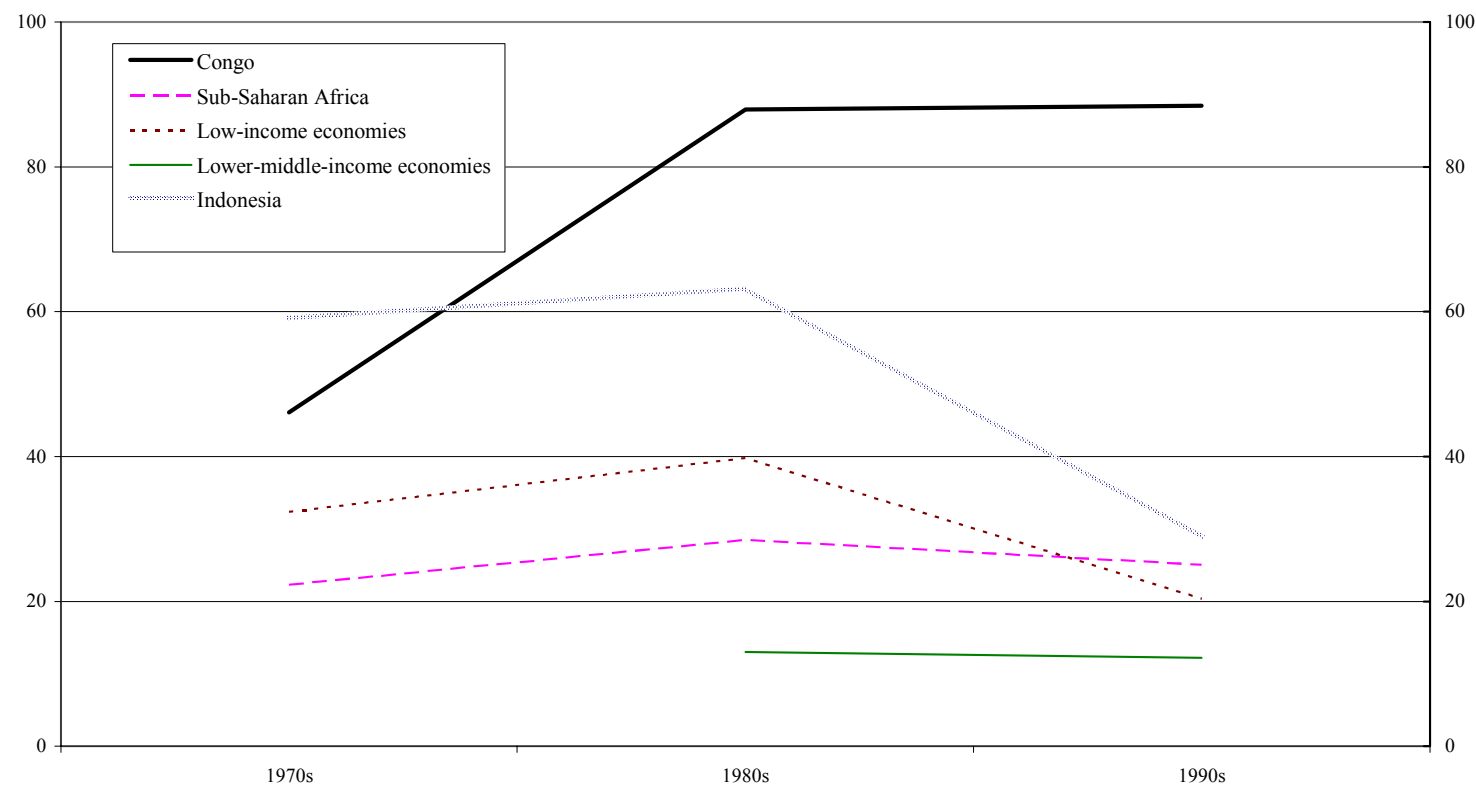

Source: World Development Indicators (World Bank) database; and Fund staff calculations.

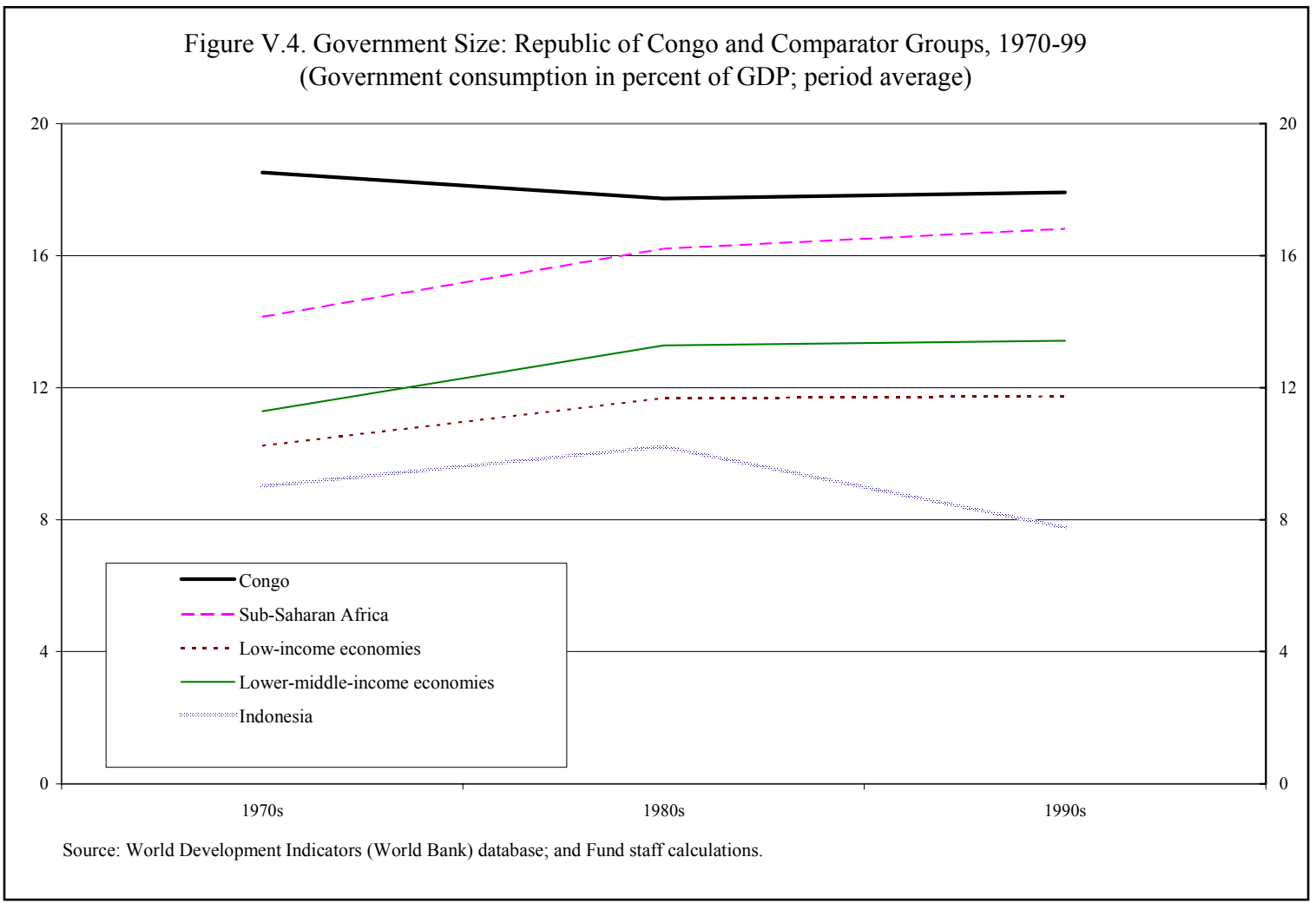

(C) International Monetary Fund. Not for Redistribution 
40. Lower degree of financial depth (Figure V.5). The Congo's broad money-GDP ratio has remained low relative to the average in comparator regions. The endogenous growth literature emphasizes the important role of financial intermediation in improving the efficiency of investment and stimulating growth (e.g., Greenwood and Jovanovic, 1990). The paper by King and Levine (1993) provides empirical evidence on the beneficial effects of financial deepening on growth. In addition, the paper by Ghura, Leite, and Tsangarides (2002) has shown that there exists a strong positive relationship between financial deepening and the income of the poor.

41. Mixed record on human capital development (Figures V.6, V.7, and V.8). The Congo made significant progress in boosting human capital development during the 1970s and 1980s. The conflicts of the 1990s, however, took a severe toll on human capital indicators, several of which either deteriorated or stagnated. Recent endogenous growth models have shown that human capital accumulation, by enhancing labor productivity, can boost growth (Lucas, 1988; Romer, 1990; and Becker, Murphy, and Tamura, 1990). The paper by Ghura and Hadjimichael (1996) finds empirical evidence on the positive impact of human capital development on economic growth in sub-Saharan Africa. In addition, the paper by Ghura, Leite, and Tsangarides (2002) has shown that there exists a strong positive relationship between secondary school enrollment ratio and the income of the poor.

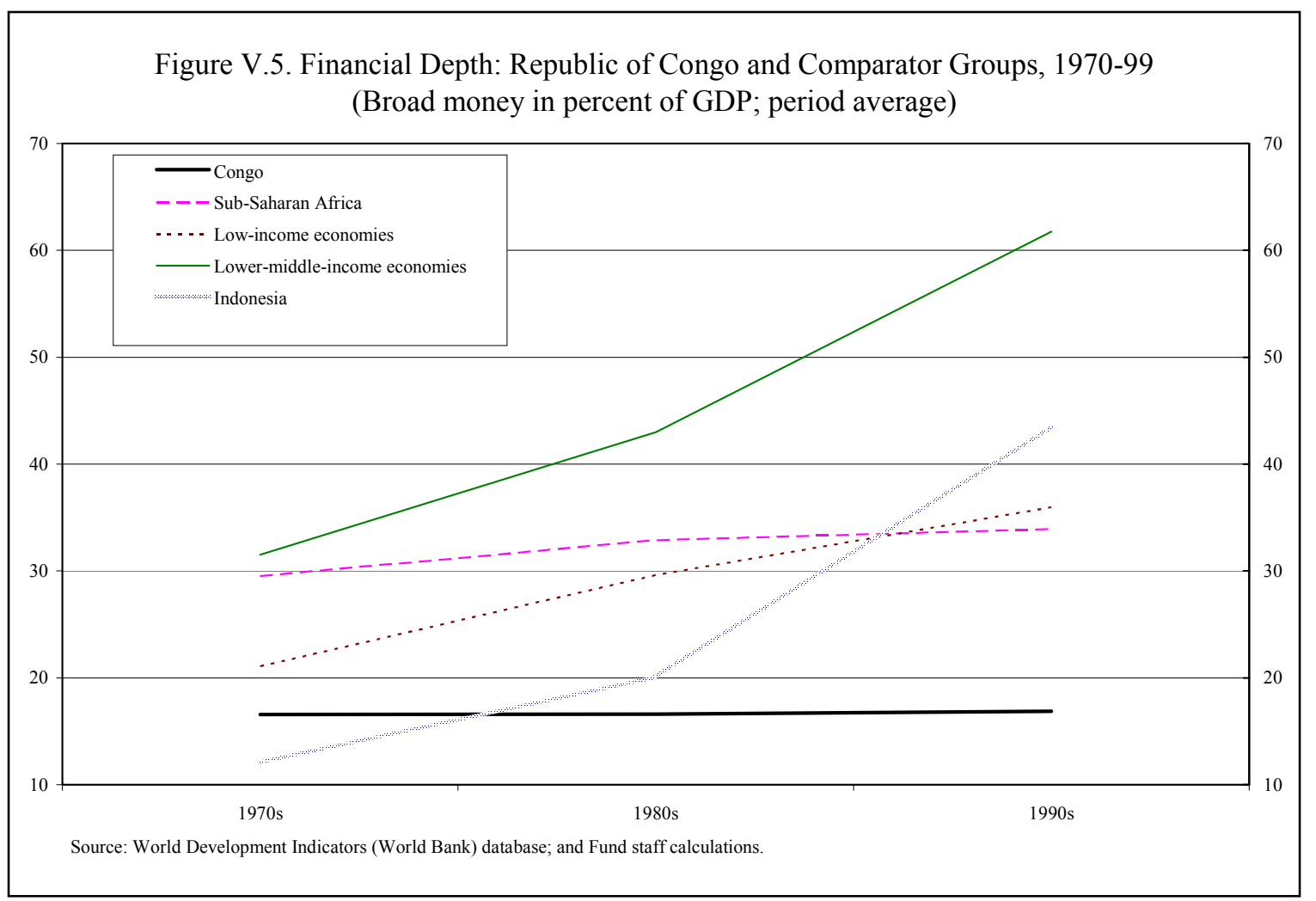

42. Higher external debt (Figure V.9). The Congo is one of the most highly indebted countries in the world, a situation made worse by the conflicts, which adversely affected the 
country's capacity to service debt. Empirical analysis has demonstrated that the adverse effect of the external debt-GDP ratio on growth is registered through both capital accumulation and total factor productivity growth (Pattillo, Poirson, and Ricci, 2004). The adverse impact of high external debt-GDP ratios on private investment can stem from two main sources. First, the resources used for servicing foreign debt crowd out public investment, which, in turn, discourages private investment, given the complementarity between these two types of investments. Second, the external debt ratio could be indicative of a "debt overhang," whereby the presence of high debt ratios leads economic agents to anticipate future tax liabilities for its servicing (Borensztein, 1990a and 1990b; and Eaton, 1987). An increasing external debt ratio could induce these agents to transfer funds abroad, thus raising the implicit domestic cost of capital. Empirical studies have found a negative relation between the external debt-GDP ratio and private investment. ${ }^{11}$

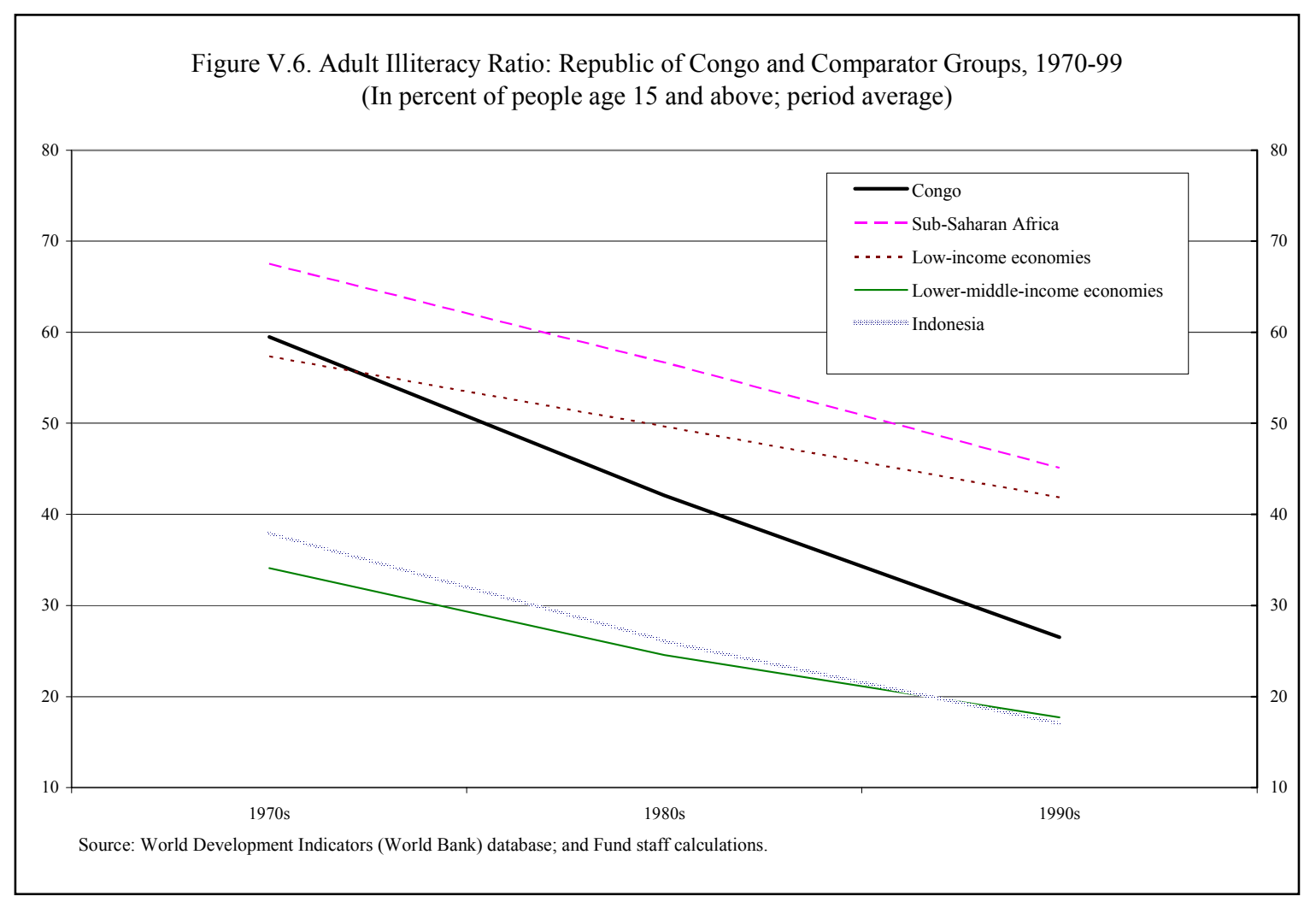

\footnotetext{
${ }^{11}$ See, for example, Borensztein (1990a and 1990b), Greene and Villanueva (1991), Oshikoya (1994), Özler and Rodrik (1992), Servén and Solimano (1993), and Larrain and Vergara (1993).
} 

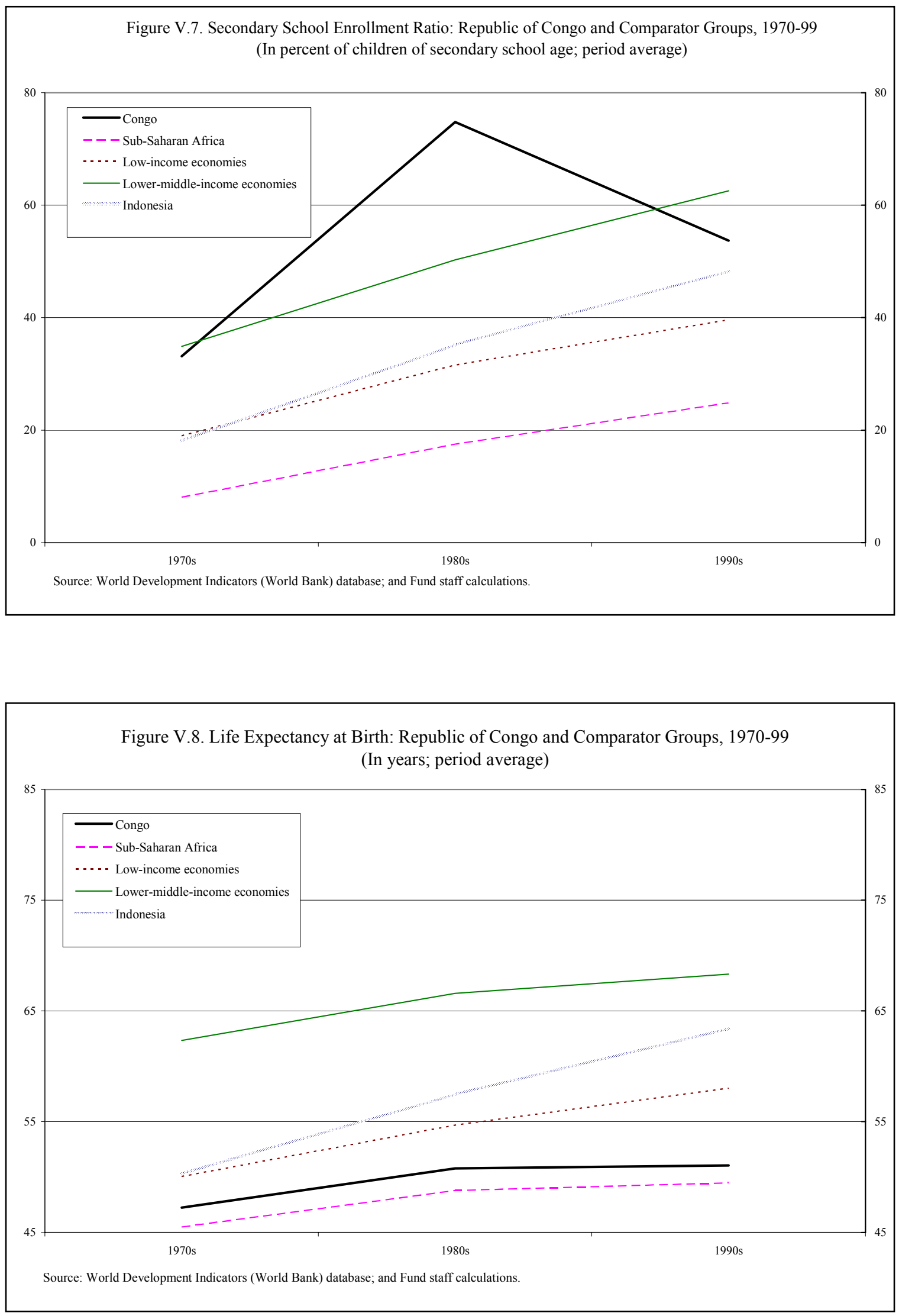

CInternational Monetary Fund. Not for Redistribution 


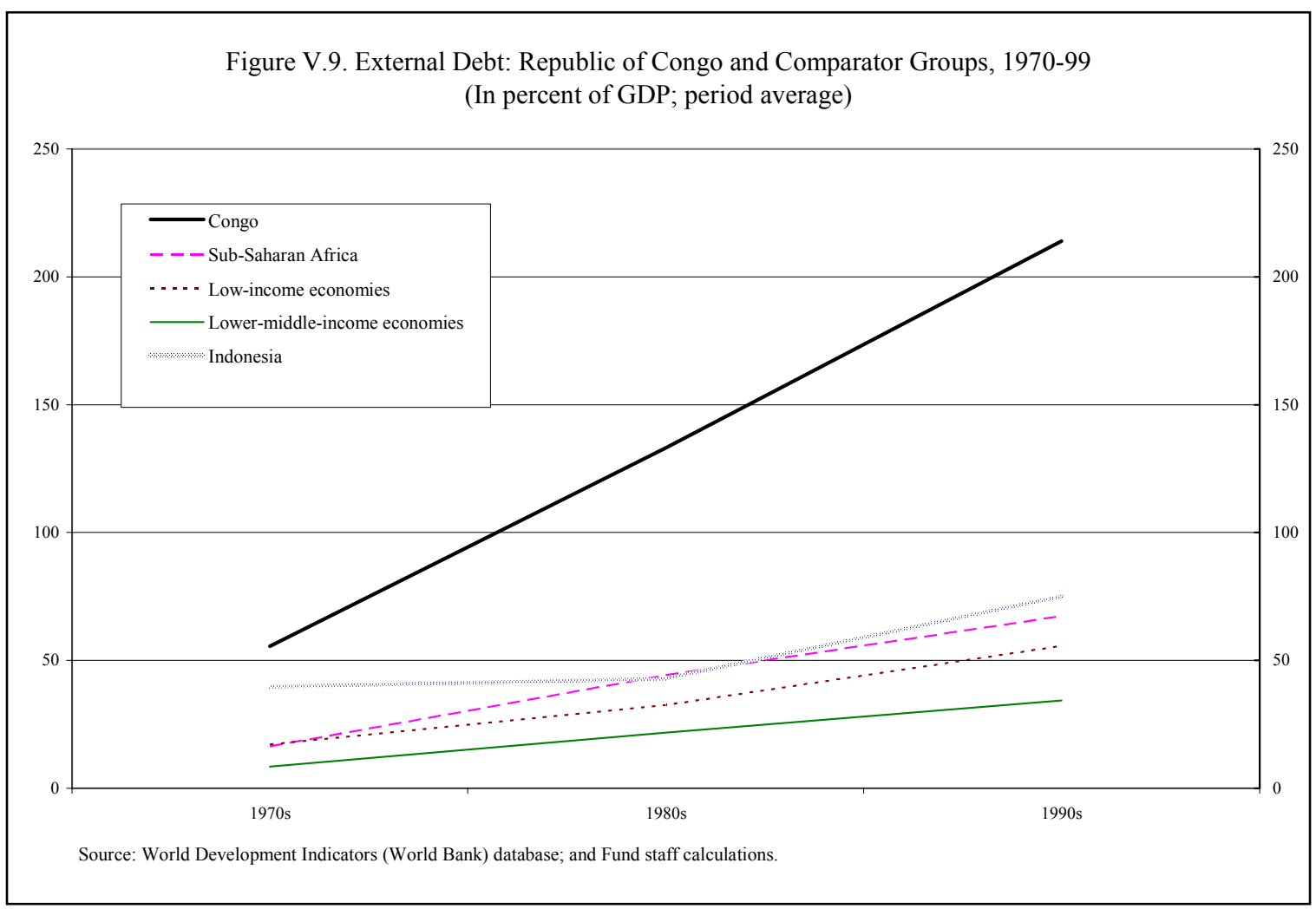

43. The Congo's institutions have also been generally weaker than in other regions. Bosworth and Collins (2003) argue that better institutions include those that deliver better law and order, better bureaucratic quality, less corruption, lower risks of expropriation, and lower probability of government repudiation of contracts. Rodrik, Subramanian, and Trebbi (2002) show empirically that economic development is positively influenced by high quality institutions. In the Congo, the legacy from past public management weaknesses and recurring bouts of civil conflict is manifested in its low governance ratings (including political stability and the rule of law).

44. Using a broad definition of governance as "the traditions and institutions by which authority in a country is exercised" and combining several individual measures into clusters, World Bank researchers have constructed aggregate indicators of six dimensions of governance (www.worldbank.org/wbi/governance/wp-governance.htm). The indicators are measured in units ranging from about -2.5 to 2.5 , with higher values corresponding to better governance outcomes (Figure V.10). The Congo's indicators generally is less favorable than comparator countries or regional averages.

45. The implications of governance for economic agents are effectively captured by assessments of the business environment carried out by COFACE (French export credit agency). According to these rankings, available at www.coface.fr, the Congo is rated as "very uncertain with a poor payment record" (the second-lowest grade on a scale of 7 points) for 
short-term deals, and as "very high risk" (the lowest grade on a scale of 4 points) for longterm investments.

46. In response, the Congo has recently established the formal institutions required by the Constitution (for example, the Court of Accounts and the Constitutional Court) and launched a process that should culminate in the preparation of a national anticorruption program. In 2003, with assistance from the United Nations Development Program, the government: (i) carried out a corruption survey, (ii) commissioned a study, and (iii) organized a seminar with the participation of officials, experts, and representatives from civil society and the international donor community. The survey established the widespread nature of corruption in the Congo: half of the 6,144 respondents reported having paid bribes to government officials. The survey also identified poverty, a lack of adequate controls, and an ineffective judicial system as the most important causes of corruption.

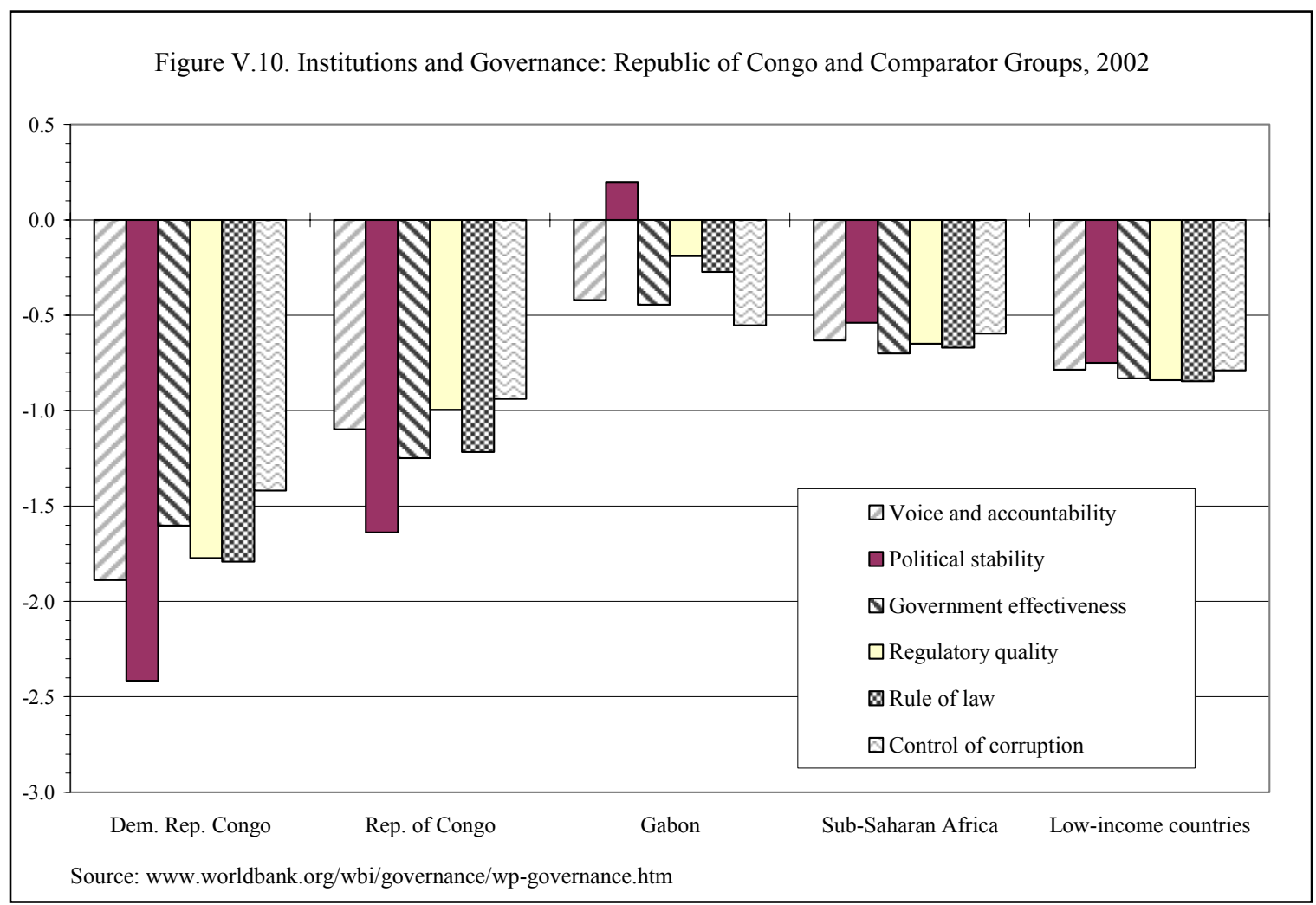

47. Finally, it needs to be noted that in relation to comparator regions or countries, the Congo had (see Table V.1): higher telephone costs (a proxy for the costs of public utilities); lower agricultural productivity (as measured by cereal yield); less infrastructure; lower access by the population to information; higher degree of urbanization; and generally higher inefficiency in capital use (as captured by the incremental capital output ratio). 


\section{References}

Barro, Robert J., 1989, "A Cross Country Study of Growth, Saving, and Government," NBER Working Paper No. 2855 (Cambridge, Mass.: National Bureau of Economic Research).

Becker, Gary S., Kevin M. Murphy, and Robert F. Tamura, 1990, "Human Capital, Fertility, and Economic Growth," Journal of Political Economy, Vol. 98 (October, Part 2), pp. S12-37.

Borensztein, Eduardo, 1990a, "Debt Overhang, Credit Rationing and Investment," Journal of Development Economics, Vol. 32, pp. 315-35.

1990b, "Debt Overhang, Debt Reduction and Investment: The Case of the Philippines," IMF Working Paper WP/90/77, (Washington: International Monetary Fund, September 1990).

Bosworth, Barry, and Susan M. Collins, 2003, "The Empirics of Growth: An Update," Brookings Institution, pp. 113-206.) Brookings Papers on Economic Activity: 2,

Collier, Paul, and Anke Hoeffler, 2002, "Greed and Grievance in African Civil Wars," CSAE Working Paper No. WPS/2002-01 (Oxford: Centre for Study of African Economies).

Eaton, Jonathan, 1987, "Public Debt Guarantees and Private Capital Flight," World Bank Economic Review, Vol. 1, (May), pp. 377-95.

Ghura, Dhaneshwar, 1995, "Macro Policies, External Forces, and Economic Growth in SubSaharan Africa," Economic Development and Cultural Change, Vol. 43 (July), pp. 759-78.

Ghura, Dhaneshwar, and Michael T. Hadjimichael, 1996, "Growth in Sub-Saharan Africa," Staff Papers, International Monetary Fund, Vol. 43 (September), pp. 605-34.

Ghura, Dhaneshwar, Carlos A. Leite, and Charalambos Tsangarides, 2002, "Is Growth Enough? Macroeconomic Policy and Poverty Reduction," IMF Working Paper 02/118 (Washington: International Monetary Fund).

Greene, Joshua, and Delano Villanueva, 1991, "Private Investment in Developing Countries: An Empirical Analysis," Staff Papers, International Monetary Fund Vol. 38, (March), pp.33-58.

Greenwood, Jeremy, and Boyan Jovanovic, 1990, "Financial Development, Growth, and the Distribution of Income," Journal of Political Economy, Vol. 98 (October), pp.1076-107.

Grier, Kevin, and Gordon Tullock, 1989, “An Empirical Analysis of Cross-National 
Economic Growth, 1951-80," Journal of Monetary Economics, Vol. 24, (September), pp. 259-76.

King, Robert G., and Ross E. Levine, 1993, "Finance and Growth: Schumpeter Might Be Right," Quarterly Journal of Economics, Vol. 108 (August), pp. 717-37.

Larrain, Felipe, and Rodrigo Vergara, 1993, "Investment and Macroeconomic Adjustment: The Case of East Asia," in Striving for Growth after Adjustment: The Role of Capital Formation, ed. by Luis, Serven, and Andres Solimano (Washington: World Bank).

Leite, Carlos and Jens Weidmann, 1999, "Does Mother Nature Corrupt? Natural Resources, Corruption and Economic Growth," IMF Working Paper 99/85 (Washington: International Monetary Fund).

Lucas, Robert E., 1988, “On the Mechanics of Economic Development," Journal of Monetary Economics, Vol. 22 (July), pp. 3-42.

Mauro, Paulo, 1995, “Corruption and Growth," Quarterly Journal of Economics, Vol. 110 (August), pp. 681-712.

Oshikoya, Temitope W., 1994, "Macroeconomic Determinants of Domestic Private Investment in Africa: An Empirical Analysis," Economic Development and Cultural Change, Vol. 42, (April), pp. 573-96.

Özler, Sule and Dani Rodrik, 1992, "External Shocks, Politics and Private Investment: Some Theory and Empirical Evidence" Journal of Development Economics, Vol. 39, pp. 141-62.

Pattillo, Catherine, Hélène Poirson, and Luca Ricci, 2004, "What are the Channels Through Which External Debt Affects Growth?” IMF Working Paper 04/15 (Washington: International Monetary Fund).

Rodrik, Dani, Arvind Subramanian, and Francesco Trebbi, 2002, "Institutions Rule: The Primacy of Institutions over Integration and Geography in Economic Development," IMF Working Paper 02/189 (Washington: International Monetary Fund).

Romer, Paul M., 1990, “Endogenous Technological Change," Journal of Political Economy, Vol. 98 (October, Part 2), pp. S71-102.

Servén, Luis, and Andres Solimano, 1993, "Economic Adjustment and Investment Performance in Developing Countries: The Experience of the 1980s," in Striving for Growth after Adjustment: The Role of Capital Formation, ed. by Luis, Serven, and Andres Solimano (Washington: World Bank).

Tornell, Aaron, and Philip Lane, 1999, “ The Voracity Effect," American Economic Review, Vol. 89 (March), pp. 22-46. 
Table V.1. Cross-Section Comparative Economic and Social Performance, 1970-99

(Period averages; in units indicated)

\begin{tabular}{|c|c|c|c|c|c|}
\hline Indicator & Congo & $\begin{array}{r}\text { Sub-Saharan } \\
\text { Africa }\end{array}$ & $\begin{array}{l}\text { Low-Income } \\
\text { Economies }\end{array}$ & $\begin{array}{r}\text { Lower-Middle- } \\
\text { Income } \\
\text { Economies }\end{array}$ & Indonesia \\
\hline \multicolumn{6}{|l|}{ Economic performance } \\
\hline GDP per capita (constant 1995 U.S. dollars) & 818 & 608 & 370 & 942 & 648 \\
\hline GDP per capita growth (annual percent change) & 1.4 & -0.1 & 1.7 & 2.5 & 4.3 \\
\hline Gross domestic investment (in percent of GDP) & 29 & 20 & 20 & 25 & 24 \\
\hline Government consumption (in percent of GDP) & 18 & 16 & 11 & 13 & 9 \\
\hline Fuel export (in percent of merchandise exports) & 74 & 25 & 31 & 13 & 50 \\
\hline Broad money (in percent of GDP) & 17 & 32 & 29 & 45 & 25 \\
\hline \multicolumn{6}{|l|}{ Cost structure/productivity } \\
\hline Telephone average cost of local call (U.S. dollars per three minutes) & 0.22 & 0.08 & 0.07 & 0.03 & 0.04 \\
\hline Incremental capital output ratio & 6.6 & 7.6 & 5.2 & 6.1 & 3.8 \\
\hline Cereal yield (kg per hectare) & 765 & 973 & 1,145 & 1,777 & 3,187 \\
\hline Fertilizer consumption (100 grams per hectare of arable land) & 198 & 134 & 395 & 965 & 869 \\
\hline \multicolumn{6}{|l|}{ External assistance/debt } \\
\hline Aid per capita (current U.S. dollars) & 54 & 21 & 9 & 6 & 6 \\
\hline External debt (in percent of GDP) & 134 & 43 & 35 & 22 & 53 \\
\hline \multicolumn{6}{|l|}{ Physical infrastructure } \\
\hline Irrigated land (percent of cropland) & 0.6 & 4.1 & 21.1 & 27.1 & 15.2 \\
\hline Paved roads (in percent of total roads) & 10 & 15 & 17 & 52 & 49 \\
\hline \multicolumn{6}{|l|}{ Social indicators } \\
\hline Adult illiteracy rate (in percent of people age 15 and above) & 43 & 56 & 50 & 25 & 27 \\
\hline Primary school enrollment ratio $1 /$ & 128 & 70 & 82 & 108 & 103 \\
\hline Secondary school enrollment ratio $2 /$ & 54 & 17 & 30 & 49 & 34 \\
\hline Immunization ratios $3 /$ & 55 & 43 & 42 & 82 & 48 \\
\hline Infant mortality rate (per 1,000 live births) & 88 & 117 & 104 & 53 & 73 \\
\hline Life expectancy at birth (in years) & 50 & 48 & 54 & 66 & 57 \\
\hline Rural access to improved water source (fraction of rural population) 4/ & 17 & 83 & 70 & 70 & 69 \\
\hline Urban access to improved water source (fraction of urban population) 4/ & 71 & 58 & 90 & 95 & 90 \\
\hline \multicolumn{6}{|l|}{ Access to information } \\
\hline Daily newspapers (per 1,000 people) & 4 & 11 & 25 & 47 & 19 \\
\hline Radios (per 1,000 people) & 85 & 136 & 96 & 201 & 115 \\
\hline Television sets (per 1,000 people) & 4 & 20 & 30 & 100 & 49 \\
\hline \multicolumn{6}{|l|}{ Population structure } \\
\hline Rural population (in percent of total population) & 52 & 77 & 75 & 65 & 73 \\
\hline
\end{tabular}

Sources: World Bank Social Indicators database; Congolese authorities; and staff estimates.

1 / In percent of the number of children of primary school age.

2 / In percent of the number of children of secondary school age.

3/ In percent of the number of children under 12 months for immunization against diphtheria, tetanus, and polio.

4/ Data available for 2000 
Table V.2. Cross Section and Time Series Comparative Economic and Social Performance, 1970-99

(Period averages in units indicated)

\begin{tabular}{|c|c|c|c|c|c|c|c|c|c|c|c|c|}
\hline \multirow[t]{2}{*}{ Indicator } & \multicolumn{3}{|c|}{ Congo } & \multicolumn{3}{|c|}{$\begin{array}{c}\text { Low-Income } \\
\text { Economies }\end{array}$} & \multicolumn{3}{|c|}{$\begin{array}{c}\text { Lower-Middle- } \\
\text { Income Economies }\end{array}$} & \multicolumn{3}{|c|}{ Indonesia } \\
\hline & $1970 \mathrm{~s}$ & $1980 \mathrm{~s}$ & $1990 \mathrm{~s}$ & $1970 \mathrm{~s}$ & $1980 \mathrm{~s}$ & $1990 \mathrm{~s}$ & 1970s & $1980 \mathrm{~s}$ & $1990 \mathrm{~s}$ & $1970 \mathrm{~s}$ & $1980 \mathrm{~s}$ & $1990 \mathrm{~s}$ \\
\hline \multicolumn{13}{|l|}{ Economic performance } \\
\hline GDP per capita (constant 1995 U.S. dollars) & 633 & 981 & 839 & 308 & 371 & 430 & 741 & 957 & 1129 & 378 & 600 & 967 \\
\hline GDP per capita growth (annual percent change) & 2.6 & 3.8 & -2.1 & 1.6 & 2.4 & 1.0 & 3.4 & 2.3 & 1.7 & 5.3 & 4.4 & 3.3 \\
\hline Gross domestic investment (in percent of GDP) & 29 & 33 & 25 & 19 & 20 & 22 & 24 & 25 & 26 & 22 & 24 & 27 \\
\hline Government consumption (in percent of GDP) & 19 & 18 & 18 & 10 & 12 & 12 & 11 & 13 & 13 & 9 & 10 & 8 \\
\hline Fuel export (in percent of merchandise exports) & 46 & 88 & 88 & 32 & 40 & 20 & $\ldots$ & 13 & 12 & 59 & 63 & 29 \\
\hline Broad money (in percent of GDP) & 17 & 17 & 17 & 21 & 30 & 36 & 31 & 43 & 62 & 12 & 20 & 44 \\
\hline \multicolumn{13}{|l|}{ Cost structure/productivity } \\
\hline Telephone average cost of local call (U.S. dollars per three minutes) & $\ldots$ & $\ldots$ & 0.22 & $\ldots$ & $\ldots$ & 0.07 & $\ldots$ & $\ldots$ & 0.03 & $\ldots$ & $\ldots$ & 0.04 \\
\hline Cereal yield ( $\mathrm{kg}$ per hectare) & 722 & 792 & 779 & 1,039 & 1,158 & 1,236 & 1,523 & 1,822 & 1,987 & 2,296 & 3,386 & 3,877 \\
\hline Fertilizer consumption (100 grams per hectare of arable land) & 302 & 120 & 173 & 181 & 406 & 597 & 587 & 1,163 & 1,146 & 284 & 956 & 1,367 \\
\hline \multicolumn{13}{|l|}{ External assistance/debt } \\
\hline Aid per capita (current U.S. dollars) & 32 & 51 & 78 & 5 & 9 & 12 & 3 & 5 & 9 & 5 & 6 & 9 \\
\hline External debt (in percent of GDP) & 56 & 133 & 214 & 17 & 32 & 56 & 9 & 22 & 34 & 40 & 43 & 75 \\
\hline \multicolumn{13}{|l|}{ Physical infrastructure } \\
\hline Irrigated land (percent of cropland) & 0.9 & 0.5 & 0.5 & 17.8 & 21.1 & 24.3 & 27.7 & 29.4 & 24.2 & 15.1 & 15.5 & 15.0 \\
\hline Paved roads (in percent of total roads) & $\ldots$ & $\ldots$ & 10 & $\ldots$ & $\ldots$ & 17 & & $\ldots$ & 52 & $\ldots$ & $\ldots$ & 49 \\
\hline \multicolumn{13}{|l|}{ Social indicators } \\
\hline Adult illiteracy rate (in percent of people age 15 and above) & 60 & 42 & 27 & 57 & 50 & 42 & 34 & 25 & 18 & 38 & 26 & 17 \\
\hline Primary school enrollment ratio $1 /$ & 128 & 144 & 111 & 70 & 86 & 91 & 102 & 111 & 112 & 83 & 112 & 113 \\
\hline Secondary school enrollment ratio $2 /$ & 33 & 75 & 54 & 19 & 32 & 40 & 35 & 50 & 63 & 18 & 35 & 48 \\
\hline Immunization ratios $3 /$ & $\ldots$ & 61 & 50 & $\ldots$ & 25 & 60 & $\ldots$ & 75 & 90 & $\ldots$ & 28 & 68 \\
\hline Infant mortality rate (per 1,000 live births) & 96 & 86 & 82 & 121 & 103 & 87 & 70 & 49 & 39 & 95 & 72 & 51 \\
\hline Life expectancy at birth ( in years) & 47 & 51 & 51 & 50 & 55 & 58 & 62 & 67 & 68 & 50 & 57 & 63 \\
\hline Rural access to improved water source (fraction of rural population) 4/ & $\ldots$ & $\ldots$ & 17 & $\ldots$ & $\ldots$ & 70 & $\ldots$ & $\ldots$ & 70 & $\ldots$ & $\ldots$ & 69 \\
\hline Urban access to improved water source (fraction of urban population) 4 / & $\ldots$ & $\ldots$ & 71 & $\ldots$ & $\ldots$ & 90 & $\ldots$ & $\ldots$ & 95 & $\ldots$ & $\ldots$ & 90 \\
\hline \multicolumn{13}{|l|}{ Access to information } \\
\hline Daily newspapers (per 1,000 people) & 1 & 3 & 8 & 14 & 19 & 41 & $\ldots$ & 43 & 51 & 14 & 17 & 25 \\
\hline Radios (per 1,000 people) & 56 & 82 & 116 & 54 & 92 & 142 & 106 & 180 & 317 & 57 & 134 & 152 \\
\hline Television sets (per 1,000 people) & 2 & 3 & 8 & 7 & 21 & 63 & 19 & 66 & 215 & 8 & 34 & 105 \\
\hline \multicolumn{13}{|l|}{ Population structure } \\
\hline Rural population (in percent of total population) & 64 & 52 & 40 & 79 & 75 & 71 & 71 & 65 & 59 & 81 & 74 & 65 \\
\hline
\end{tabular}

Source: World Bank Social Indicators database; Congolese authorities; and staff estimates.

$1 /$ In percent of the number of children of primary school age.

$2 /$ In percent of the number of children of secondary school age.

$3 /$ In percent of the number of children under 12 months for immunization against diphtheria, tetanus, and polio.

4/ Data available for 2000. 


\section{SOURCES OF ECONOMIC GROWTH, 1970-2003 ${ }^{12}$}

48. The analysis of the sources of growth, using the growth-accounting framework, has received considerable attention for the countries in East Asia. ${ }^{13}$ The related debate has centered on whether the "East Asian miracle" was driven primarily by factor accumulation (capital and labor) or total factor productivity (TFP). For sub-Saharan Africa, while a number of papers have looked at the determinants of economic growth in the region, ${ }^{14}$ more recently, few have analyzed the sources of growth from a growth-accounting perspective. The bulk of the analysis points to factor accumulation as the main source of growth in sub-Saharan Africa, with the contribution of TFP growth playing a limited role. ${ }^{15}$ This section examines the sources of growth in the Congo over the period 1970-2003, using the growth-accounting framework.

49. Bosworth and Collins (2003) have argued that the growth-accounting framework is a useful tool to understand growth experiences across countries. The same authors have, however, noted the limitations of this methodology. A key weakness relates to the interpretation that the measured residual from the growth accounting exercise represents TFP growth. In practice, in addition to providing a measure of gains in economic efficiency, the residual may also reflect a number of other factors, including political disturbances and conflicts, institutional changes, droughts, external shocks, changes in government policies, and measurement errors. This limitation is particularly important for sub-Saharan African countries, such as the Congo, mired in conflicts and subject to significant drought-related and external shocks. Also, the results from a growth-accounting exercise should not be misconstrued as providing the fundamental causes of growth (rather than the proximate sources of growth).

50. The growth-accounting framework used for the analysis of the sources of growth is based on the following production function:

$$
Y=A L^{0.6} K^{0.4},
$$

where $Y$ is real GDP, $A$ is total factor productivity (TFP), $L$ is labor, and $K$ is physical capital. The capital stock series was constructed by using the perpetual inventory accumulation

${ }^{12}$ This section was prepared by Dhaneshwar Ghura.

${ }^{13}$ See, for example, Bosworth and Collins (2003), Collins and Bosworth (1996), and Krugman (1994).

${ }^{14}$ For recent surveys on this subject, see Fosu (2001) and McPherson and Rakovski (2001).

${ }^{15}$ See, for example, the paper by Tahari and others (2004). 
framework, and assuming a constant depreciation rate of 6 percent and a capital-output ratio of 1.5 in 1960. The share of capital of 0.4 is in line with the empirical finding by Senhadji (2000) for sub-Saharan Africa.

51. The main results of the analysis are provided in Table VI.1 and Figure VI.1. It should be noted up-front that there are a number of weaknesses to this exercise, most notably the lack of data on the capacity utilization and the unemployment rate, which are needed to adjust the capital stock and labor force series, respectively. Hence, the results need to be viewed as indicative. They are summarized as follows:

- 1970-2003. Factor accumulation explained the bulk of output growth during this period, with TFP playing a limited role.

- 1970-74. The high output growth rate is explained by the significant expansion in oil production and the initial boost in productivity.

- 1980-84. The boost in non-oil real GDP is explained primary by government intervention to prop up output, including by significantly raising producer prices for agricultural crops and by boosting public investment. The increase in the "Solow residual" represented partly the change in government marketing policies for agricultural products (see Section III).

- 1985-89. Starting in the second half of the 1980s, the decline in non-oil real GDP growth appears to have been caused by a loss in competitiveness and to have been accompanied by an acceleration of rural-to-urban migration. The loss of competitiveness in the non-oil sector was due to the overvaluation of the CFA franc - while the terms of trade declined significantly on a secular basis between the first half of the 1980s and the second half, the real effective exchange rate remained virtually unchanged. The acceleration of the rural- to-urban migration may have been due to the (i) existence of oil-related rents, including in the form of public services, in urban areas; and (ii) the dismantling of inefficient, loss-making agricultural marking agencies in the areas of coffee, cocoa, and food crops.

- 1990-99. Non-oil real GDP growth was adversely affected by the civil conflicts, which took a severe toll on physical and human capital. The expected benefits from the 1994 devaluation of the CFA franc were overshadowed by the devastation from the conflicts. Government efforts to prop up capital expenditure in the second half of the 1990s had a limited impact, owing to the lack of security and other constraints on growth.

- 2000-03. The pickup in non-oil real GDP growth-following the transition period to a democracy and the signing of peace agreements - has been accompanied by a boost in government investment. The increase in the "Solow residual" represented partly a "catch-up" to more normal economic activities following the return of more normal living conditions. 
Figure VI.1. Republic of Congo: Sources of Economic Growth, 1975-2003

(Five-year moving average; in percentage change)

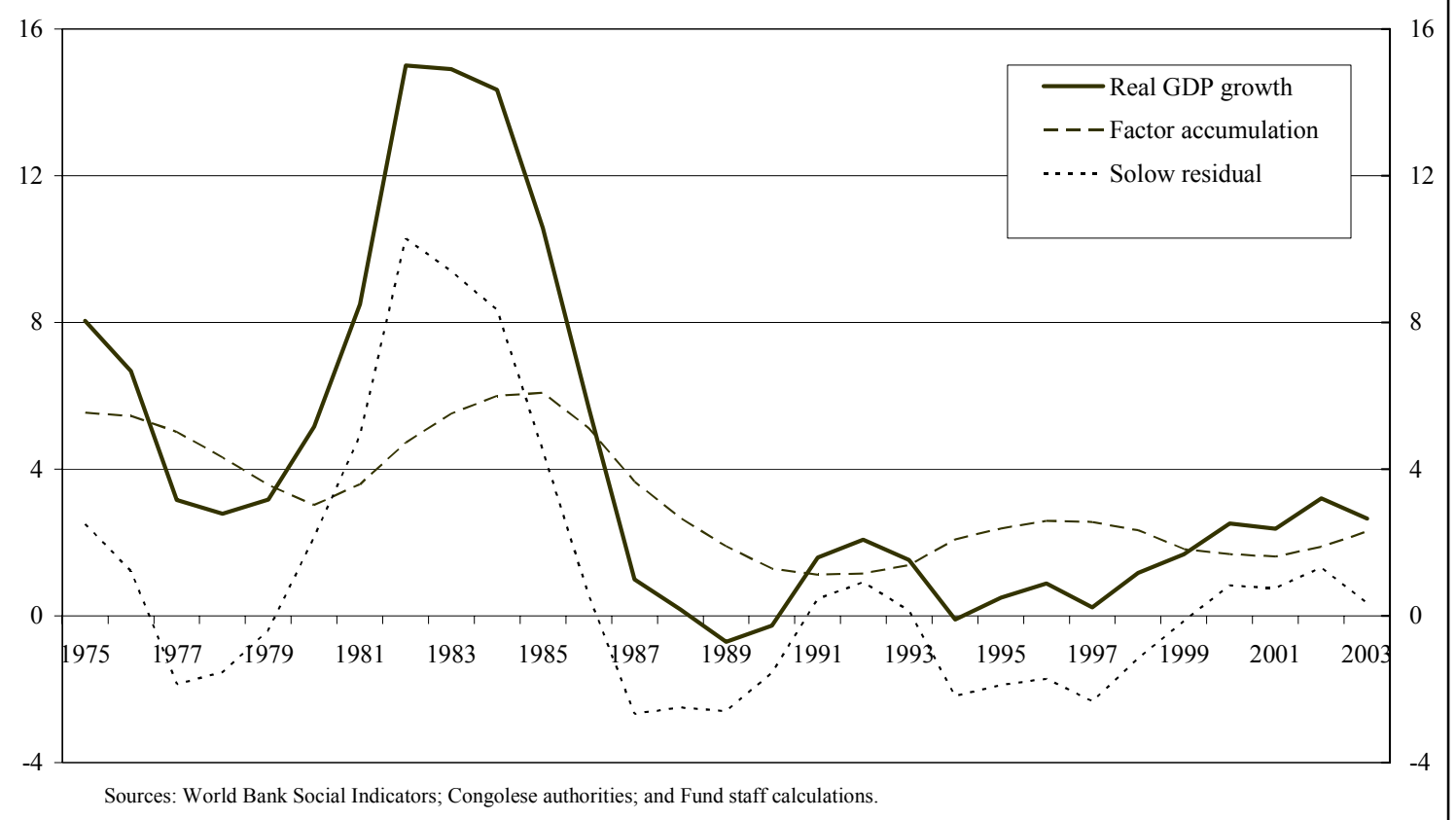


Table VI.1. Republic of Congo: Sources of Economic Growth, 1970-2003 (In percentage change; unless otherwise indicated)

\begin{tabular}{|c|c|c|c|c|c|c|c|c|}
\hline & 1970-74 & $1975-79$ & $1980-84$ & $1985-89$ & $1990-94$ & 1995-99 & $2000-03$ & $1970-2003$ \\
\hline Real GDP growth & 7.8 & 3.2 & 14.3 & -0.7 & -0.1 & 1.7 & 4.1 & 4.3 \\
\hline Factor accumulation 1/ & 5.1 & 3.6 & 6.0 & 1.9 & 2.1 & 1.8 & 2.5 & 3.3 \\
\hline Solow residual & 2.7 & -0.4 & 8.3 & -2.6 & -2.2 & -0.1 & 1.6 & 1.0 \\
\hline \multicolumn{9}{|l|}{ Memorandum items: } \\
\hline Non-oil sector real GDP growth & 3.0 & 4.2 & 14.9 & -3.3 & -1.7 & -2.8 & 10.3 & 3.3 \\
\hline Oil sector real GDP growth & 86.5 & 1.9 & 12.5 & 9.3 & 3.8 & 9.1 & -4.3 & 17.6 \\
\hline Investment-GDP ratio (in percent) & 29.4 & 30.0 & 42.5 & 22.4 & 28.4 & 29.2 & 23.5 & 29.5 \\
\hline Public investment-GDP ratio & 2.8 & 4.8 & 19.8 & 7.7 & 1.8 & 6.0 & 8.1 & 7.3 \\
\hline Capital stock growth & 9.0 & 5.0 & 10.8 & 0.4 & 0.9 & 0.1 & 1.8 & 4.1 \\
\hline Labor growth & 2.4 & 2.6 & 2.8 & 2.9 & 2.9 & 3.0 & 2.9 & 2.8 \\
\hline Secondary school enrollment ratio & 18.6 & 47.6 & 74.1 & 75.4 & 54.1 & 52.5 & 41.9 & 52.8 \\
\hline Exports of goods and services volume & 8.7 & 5.6 & 13.4 & 2.2 & 1.4 & 7.2 & 2.4 & 6.0 \\
\hline Terms of trade $2 /$ & 91.0 & 83.5 & 179.6 & 125.8 & 84.1 & 78.0 & 124.2 & 109.0 \\
\hline Real effective exchange rate $2 /$ & 108.3 & 109.8 & 96.7 & 98.8 & 92.7 & 79.3 & 80.2 & 95.6 \\
\hline Rural population 3/ & 66.4 & 62.7 & 56.4 & 50.1 & 44.6 & 40.0 & 36.4 & 51.4 \\
\hline
\end{tabular}

Sources: Congolese authorities; and staff calculations.

1/ Accumulation of capital and labor, using 0.4 and 0.6 as factor shares, respectively.

2/ Index, 1990=100.

$3 /$ In percent of total population. 


\section{References}

Bosworth, Barry, and Susan M. Collins, 2003, "The Empirics of Growth: An Update," Brookings Institution, pp. 113-266. Brookings Papers on Economic Activity: 2.

Collins, Susan, M. and Barry Bosworth, 1996, "Economic Growth in East Asia:

Accumulation versus Assimilation," Brookings Papers on Economic Activity: 2, pp. 135-203.

Fosu, Augustin Kwasi, 2001, “ The Global Setting and African Economic Growth,” Journal of African Economies, Vol. 10, (September), pp. 282-310.

Krugman, Paul, 1994, “The Myth of Asia's Miracle," Foreign Affairs, Vol. 73 (NovemberDecember), pp. 62-78.

McPherson, Malcolm F., and Tzvetana Rakovski, 2001, "Understanding the Growth Process in Sub-Saharan Africa: Some Empirical Estimates," African Economic Policy Discussion Paper No. 54 (Washington: United States Agency for International Development).

Senhadji, Abdelhak, 2000, "Sources of Economic Growth: An Extensive Growth Accounting Exercise," Staff Papers, International Monetary Fund, Vol. 47, (January-April), pp. 129-57.

Tahari, Amor, and others, 2004, "Sources of Growth in Sub-Saharan Africa" (unpublished; Washington: International Monetary Fund). 


\section{Prudent Management of OIL Wealth ${ }^{16}$}

52. As noted in Section V, the Republic of Congo (hereafter "the Congo") exhibits one of the highest rates of dependence on a nonrenewable resource in the world, with approximately 90 percent of merchandise exports and 70 percent of fiscal revenues derived directly from sales of crude oil. Such dependence has been shown to be theoretically and empirically associated with lower rates of long-run economic growth through (i) economic channels (for example, a loss of competitiveness in tradable sectors), (ii) institutional channels (for example, an increase in the incidence of corruption or rent seeking), and (iii) political channels (an increase in the probability of civil conflicts). Moreover, periodic reversals in oil prices and the nonrenewable nature of oil reserves present ongoing challenges for policymakers.

53. Over the past two decades, the Congo has experienced firsthand most of the hazards associated with extreme dependence on petroleum. The massive increase in oil production in the late 1970s and early 1980s was accompanied by decreases in other tradable sectors, including coffee and cocoa. Corruption is now considered endemic in the country, and the quality of institutions is evaluated as below average within sub-Saharan Africa (see Section V). Outbreaks of civil conflict throughout the 1990s inflicted considerable human and physical damage, particularly in the administrative capital, Brazzaville (see Section II). Finally, the protracted economic slump that originated in the second half of the 1980s was triggered by the failure of policymakers to adjust to a sudden drop in oil prices (see Section III).

54. Recent Fund-supported programs have emphasized the need for substantial improvements in governance and transparency in the oil sector in order to begin to lay the groundwork for more economically sound public policies, enhanced political stability, and sustained private sector development. Within this framework, one of the key challenges facing Congolese policymakers is ensuring policy sustainability, particularly in light of the current levels of reliance on the oil sector. In this section, the precepts of the permanent income theory are used to evaluate the sustainability of the fiscal policy stance. ${ }^{17}$

\section{A. Fiscal Sustainability}

55. The litany of economic hazards associated with a high degree of reliance on natural resources implies that using the conventional measures to assess the sustainability of the fiscal stance can be misleading for countries highly dependent on nonrenewable resources. ${ }^{18}$

${ }^{16}$ This section was prepared by Carlos Leite.

${ }^{17}$ This analysis does not explicitly account for feedback effects between fiscal policy and the response by the private sector.

${ }^{18}$ Typically, fiscal policy sustainability is assessed on the basis of a country's explicit debt burden and its projected dynamics over the medium term. 
Aside from the problems of slower growth noted above, these countries have unique characteristics because resource extraction implies a change in national wealth whose value is not typically recorded in the national accounts, whose size is subject to considerable uncertainty, and whose price has been historically volatile. Therefore, an assessment of fiscal policy sustainability must explicitly account for the nonrenewable nature of the assetgenerating fiscal oil revenues and the volatility in its assessed economic value. For forwardlooking policymakers, the crucial issue can be framed in the form of a portfolio problem: what level of total assets, and which combination of oil reserves or other assets (principally, financial wealth or higher productive capacity) should future generations be endowed with?

56. In these cases, the permanent income theory provides a useful rule of thumb: the government should consume at most the annuity value of its total wealth (instead of setting the level of expenditures on the basis of current resources). Therefore, the sustainable level of government consumption is no higher than this rent, and over time, other assets should substitute oil resources as the latter diminish in value. Without such restraints on fiscal spending, the value of total wealth can be eroded over time if resource extraction is too high or financial wealth accumulation too low. This policy prescription is consistent with an objective of maintaining the level of national (oil) wealth constant forever (i.e., intergenerational equity) and ensuring that governments can deliver to future generations a constant level of per capita services. ${ }^{19}$

57. A measure of government consumption that is consistent with the notions of the permanent income theory, as applied to the case of oil producers, is the non-oil current fiscal balance. The appeal of this measure derives from the fact that, in abstracting from the volatility of oil prices and revenue, it provides a better indicator of underlying fiscal trends. Under this measure, capital expenditures are considered investments, and all current expenditures, including spending on education and health, are considered consumption. ${ }^{20}$

\section{B. Fiscal Policy in the Congo}

58. The present value of the Congo's public wealth at end-2002 is estimated at about US $\$ 28.8$ billion (equivalent to 950 percent of GDP), composed mainly of oil wealth of US\$36.1 billion and public external debt of US\$7.4 billion. The estimate of oil wealth is based on the following key assumptions:

${ }^{19}$ Trivially, an increase in non-oil revenue will raise the level of sustainable current expenditures. The caveat is that consistency with intergenerational equity requires that such increases in revenue result from economic growth rather than a heavier tax burden.

${ }^{20}$ In this analysis, no allowance is made for depreciation of capital stock. Additionally, investing in financial assets is considered equivalent to capital expenditures. The usual caveat applies: physical investments should generate an economic rate of return at least equal to the real rate of return on financial assets. 
- oil reserves of 7.3 billion barrels, ${ }^{21}$

- international oil prices similar to projections under the World Economic Outlook,

- a discount rate of 3.5 percent per annum,

- extraction costs of US\$5 per barrel, and

- production levels rising from the 2003 level of roughly 210,000 barrels per day to just over 290,000 barrels per day by 2008 and stabilizing thereafter (as new field production begins to offset reduced output at more mature fields).

59. Table VII.1 below presents the base case, with oil prices and reserves as outlined above, and two alternative scenarios: (i) lower oil prices in the outer years, and (ii) lower initial oil reserves. Columns labeled as "Target" indicate the maximum level of non-oil current fiscal deficit compatible with the permanent income hypothesis.

60. Under the base case, the non-oil current fiscal deficits for 2003 exceeded the level compatible with prudent management of oil reserves ${ }^{22}$ but the macroeconomic scenario projected by the staff over the period 2004-08 (see column labeled as "Proj") is broadly consistent with the guidelines from the permanent income hypothesis. ${ }^{23}$

61. However, the high degree of vulnerability to oil sector shocks is clearly illustrated by the alternative scenarios. A relatively small decrease in the outlook for oil prices (essentially a drop of US\$1.50 per barrel, starting in 2005) or a reduction in estimated reserves (in this case, using only the figure for proven reserves) necessitates substantial fiscal adjustment in order to ensure prudent management of oil resources.

${ }^{21}$ Publicly available data estimates proven reserves at 1.5 billion barrels (unchanged since 1996 despite significant discoveries in the intervening period). Based on geological data, undiscovered reserves are estimated at 5.8 billion barrels on a risk-weighted basis (www.eia.doe.gov). The national oil company (SNPC), claims that the Congo's reserves are approximately 23 billion barrels. For this analysis, current reserves are estimated at 7.3 billion barrels (proven plus undiscovered sources) with no additional discoveries projected during the forecast period. Such an assumption is equivalent to starting with the lower publicly-available estimate and then projecting increases in reserves (as happened in early 2004 with an onshore field operated by Maurel \& Prom, for example); the economic valuation is based on the production profile and not on reserves available at a particular point in time.

${ }^{22}$ Depreciation costs on existing capital stock are not included in current expenditures.

${ }^{23}$ Current projections do not include the net fiscal impact of HIPC Initiative-related expenditures (which would have the tendency to increase the fiscal deficit). 
62. In conclusion, it is worth emphasizing the following:

- The high degree of vulnerability to external shocks indicates that precautionary saving, in addition to the level of saving implied by the permanent income theory, may be advisable.

- Ensuring that the financial savings from a prudently designed fiscal policy are adequately managed requires a transparent institutional framework with strong safeguards. The experience of 2003, when the budget was based on a conservative oil price but the windfall revenues were used on unbudgeted outlays, is a reminder of the importance of this point.

- Public investments must earn at least the real rate of return on financial savings in order to be economically rational. Notwithstanding the urgency of the task of national reconstruction, the current level of absorption of the Congolese economy is likely to be low, a situation that calls for caution in projection selection.

- The exhaustible nature of oil resources implies that sustainable economic growth ultimately requires that current and future generations adopt policies geared to ensuring a sustained rise in the productivity of the non-oil economy. 
Table VII.1. Republic of Congo: Fiscal Sustainability Approach Based on Intergenerational Objectives, 2003-13 1/ 2/ (In percent of GDP)

\begin{tabular}{|c|c|c|c|c|c|c|}
\hline & \multicolumn{2}{|c|}{2003} & \multicolumn{2}{|c|}{ 2004-2008 } & \multicolumn{2}{|c|}{$2009-2013$} \\
\hline & Est. & Target & Proj. & Target & Proj. & Target \\
\hline \multicolumn{7}{|c|}{ I. Base case } \\
\hline Non-oil current fiscal deficit 3 / & 12.0 & 8.4 & 8.5 & 7.5 & 5.3 & 5.4 \\
\hline \multicolumn{7}{|l|}{ Parameters: } \\
\hline World oil price (U.S. dollars per barrel) 4/ & 28.5 & 28.5 & 22.8 & 22.8 & 21.5 & 21.5 \\
\hline Oil reserves (millions of barrels) $5 /$ & $\ldots$ & 7,216 & 7,138 & 7,138 & 6,656 & 6,656 \\
\hline \multicolumn{7}{|c|}{ II. Sensitivity analysis } \\
\hline \multicolumn{7}{|l|}{ Scenario A } \\
\hline Non-oil current fiscal deficit & $\ldots$ & 8.2 & $\ldots$ & 7.2 & $\ldots$ & 4.8 \\
\hline Parameter changes from base case: & & & & & & \\
\hline World oil price (U.S. dollars per barrel) 6/ & $\ldots$ & $\ldots$ & $\ldots$ & 21.1 & $\ldots$ & 20.0 \\
\hline \multicolumn{7}{|l|}{ Scenario B } \\
\hline Non-oil current fiscal deficit & $\ldots$ & 7.2 & $\ldots$ & 6.2 & $\ldots$ & 3.4 \\
\hline \multicolumn{7}{|l|}{ Parameter changes from base case: } \\
\hline Oil reserves (millions of barrels) & $\ldots$ & 1412.0 & $\ldots$ & 1330.3 & $\ldots$ & 837.9 \\
\hline \multicolumn{7}{|l|}{ Scenario C } \\
\hline Non-oil current fiscal deficit & $\ldots$ & 8.0 & $\ldots$ & 7.5 & $\ldots$ & 5.7 \\
\hline \multicolumn{7}{|l|}{ Parameter changes from base case: } \\
\hline Extraction costs (U.S. dollars per barrel) & $\ldots$ & 8.0 & $\ldots$ & 8.0 & $\ldots$ & 8.0 \\
\hline \multicolumn{7}{|l|}{ Memorandum item: } \\
\hline Oil production (millions of barrels) & 81.7 & 81.7 & 98.5 & 98.5 & 110.0 & 110.0 \\
\hline
\end{tabular}

Source: Fund staff estimates.

1/ Holding constant the level of total wealth per capita; where total wealth includes present value of oil wealth, stock of public external debt and net financial assets.

2/ For 2003-08 and 2009-12, data shown are period averages (except oil reserves which are estimates for beginning of period). "Target" indicates the maximum level of non-oil current fiscal deficit compatible with the permanent income hypothesis.

3/ Non-oil revenue less non-oil current expenditures.

4/ World oil price beyond 2014 estimated at US\$21.50 per barrel.

5/ Beginning of period; for 2002, proven reserves of 1,500 million barrels and risk-weighted mean estimate of undiscovered reserves of 5,800 million barrels.

6/ World oil price for 2004 is the same as the base case (US\$25.5 per barrel); for 2005 and beyond, price drops to US\$20.00 per barrel. 


\section{Key LeSSONS AND CHALlengeS}

63. The evaluation of the Congo's economic and social performance during 1970-2003 suggests a number of lessons on to address the central challenges facing the country.

\section{A. Avoiding Conflicts}

64. As noted in Section II, the economic and social costs of the recent conflicts were enormous. Therefore, a crucial challenge for the Congolese government is to put in place the conditions necessary for a substantial reduction in the likelihood of future conflicts. This will require intense efforts in order to:

- $\quad$ Secure social stability by promptly implementing the proposed demobilization program for former combatants.

- $\quad$ Strengthen the institutional framework that supports the country's democratic constitution (such as the Court of Accounts, the Economic and Social Council, and the Constitutional Court).

- Achieve significant improvements in living conditions through the efficient delivery of government services and more equitable distribution of oil wealth. The dislocations caused by the recent conflicts make it even more imperative to place poverty reduction at the top of the priority list of economic policy objectives.

- Increase governance in the oil sector, including through greater transparency on oil-related revenues and improved management of oil sector activities. More generally, public access to economic and social information should be a key component of attempts to improve decision-making, strengthen accountability, and mobilize internal and external support for reform efforts.

- $\quad$ Broaden the policy discussions and expand ownership of the reform process by entrenching democratic institutions, and installing effective policy deliberation mechanisms and transparent decision-making practices.

\section{B. Avoiding Pro-Cyclical Government Spending}

65. As described in Section III, public investment has tended to be pro-cyclically related to oil revenue, thereby transmitting oil-sector volatility to the rest of the economy. The resulting boom-bust cycles of economic activity appear, in turn, to be correlated with the onset of conflicts. A transparent policy framework, underpinned by the institutionalized rational use of oil rents could be instrumental in strengthening the management of public resources and preventing frenzied levels of rent seeking activities. Recent oil sector developments, including continuing high international prices and brighter perspectives on production levels in the Congo, make it imperative to break with past policy trends. 
66. A key component of such a strategy could be a price rule geared to ensuring the sustainability of fiscal policy. Complementary elements would include: wide ranging discussions at the level of the parliament and civil society to ensure the mechanism and its objectives are well understood and widely endorsed, and wide dissemination of regular and timely updates on budgetary execution. At a more technical level, it would be crucial to carefully vet decisions on public investment projects to safeguard the efficiency of capital use and to ensure a significant contribution to productive capacity.

\section{Promoting Private Sector Growth}

67. As noted in Section V, economic growth in the non-oil sector faces significant structural impediments. The importance of meeting this challenge arises primarily from the non-renewable nature of oil, and the lack of economic linkages from the oil sector to the rest of the economy. In order to enhance competitiveness in the non-oil sector, the government in concert with its development partners must urgently tackle the fundamental causes of high transaction costs. In the immediate term, key challenges include enhancing the overall governance framework and effectively combat corruption, improving efficiency in the delivery of public utilities, and promoting financial deepening.

68. To promote good governance, the government has recently: (i) enacted a code of conduct for civil servants and the enabling regulations for the related disciplinary councils; (ii) started preparing, with assistance from the UNDP, a National Anti-corruption Program; and (iii) proposed to the Council of Ministers the establishment of a National AntiCorruption and Anti-Fraud Commission. A detailed strategy would provide a roadmap for follow-up actions and its wide dissemination would mobilize efforts and resources to assist with effective implementation of the action plan.

69. Additionally, it is urgent to:

- $\quad$ Accelerate reforms in the water, electricity, telecommunications, and rail transport sectors, in order to begin to reduce the high costs of doing business in the non-oil sector.

- $\quad$ Reinforce the legal and judicial framework to promote a stable business environment.

- $\quad$ Nurture the ongoing expansion in the activities of the micro-finance sector, including by maintaining the tax exempt status of mutual micro-finance institutions whose activities are closely linked to poverty reduction efforts. This sector promises to significantly expand the availability of financial sector services to a segment of the population which, to date, is excluded from the more formal banking sector.

\section{Alleviating the Debt Burden}

70. The Congo is one of the most heavily indebted countries in the world, on the basis of per capita debt levels. It needs assistance from the international community to remove this debt overhang, and therefore, putting in place the conditions necessary to ensure such 
assistance is an immediate challenge. Given the structure of the Congo debt, exceptionally favorable treatment will be required from external creditors on certain categories of external arrears.

71. The international community, in turn, will need assurances from the government that it is making the maximum effort to: implement structural reforms, and to mobilize domestic resources and utilize them judiciously. Particularly critical for future debt sustainability is the adoption of sound debt management policies, including the elimination of the practice of contracting oil-collateralized debt. For reasons of social stability, domestic payment arrears should be settled in a transparent manner on the basis of a comprehensive domestic arrears settlement plan that is widely published. International debt relief should complement the country's own efforts at mobilizing resources to raise spending aimed at poverty-reduction. 
Republic of Congo: Basic Data, 1997-2003

\author{
Area \\ Population (2001 estimates) \\ Total \\ Annual growth rate \\ GNI per capita
}

341,500 sq. kilometers

3.1 million

2.8 percent

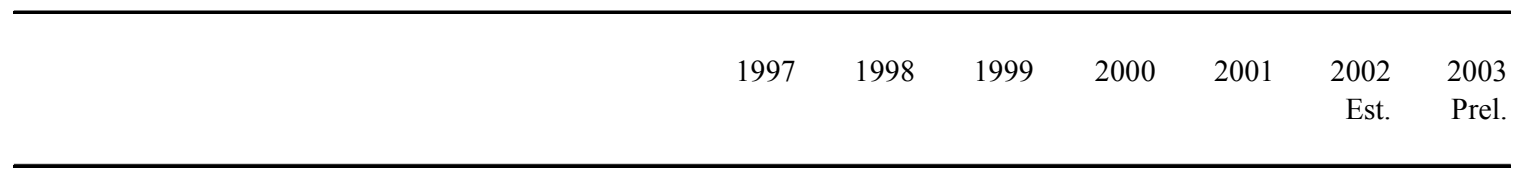

National accounts

(Annual percentage change)

\section{Real GDP \\ GDP deflator \\ Consumer price index \\ Period average \\ End of period}

$\begin{array}{rrrrrrr}-0.6 & 3.7 & -3.0 & 8.2 & 3.6 & 4.6 & 1.3 \\ 5.0 & -18.2 & 29.9 & 46.1 & -13.9 & -1.7 & -2.7 \\ & & & & & & \\ 13.2 & 1.8 & 3.1 & 0.4 & 0.8 & 3.1 & 1.2 \\ 16.4 & -2.7 & 4.1 & -3.3 & 8.3 & -2.8 & 2.7\end{array}$

(In billions of CFA francs)

Gross domestic product in nominal

terms at factor cost

Primary sector

Secondary sector

Tertiary sector

$\begin{array}{rrrrrrr}1,325.5 & 1,100.2 & 16.9 & 19.6 & 18.9 & 23.9 & 23.8 \\ 123.9 & 126.0 & 852.5 & 1,582.0 & 1,249.2 & 1,236.5 & 1,168.5 \\ 770.9 & 529.7 & 224.2 & 296.6 & 341.1 & 385.4 & 416.7 \\ 430.7 & 444.5 & -1,059.8 & -1,859.0 & -1,571.4 & -1,598.0 & -1,561.4\end{array}$

Gross domestic product at current market prices

$\begin{array}{lllllll}1,355.7 & 1,150.1 & 1,449.3 & 2,292.5 & 2,043.4 & 2,103.0 & 2,073.0\end{array}$

Imports of goods and services

$\begin{array}{lllllll}815.6 & 835.3 & 856.6 & 999.8 & 1,092.0 & 1,135.4 & 1,093.8\end{array}$

Total supply of resources

$=$ total use of resources

$2,171.3 \quad 1,985.4 \quad 2,305.9 \quad 3,292.3 \quad 3,135.4 \quad 3,238.4 \quad 3,166.8$

Exports of goods and services

$\begin{array}{lllllll}1,025.2 & 877.4 & 1,047.9 & 1,841.0 & 1,636.3 & 1,696.4 & 1,608.0\end{array}$

Domestic demand

Consumption

Private consumption

Public consumption

Investment

Of which: gross fixed capital formation

$\begin{array}{rrrrrrr}1,146.0 & 1,108.0 & 1,258.0 & 1,451.3 & 1,499.1 & 1,541.9 & 1,558.8 \\ 844.6 & 801.1 & 855.5 & 969.5 & 959.2 & 1,052.0 & 1,085.2 \\ 560.6 & 522.8 & 637.2 & 704.3 & 670.6 & 665.6 & 732.5 \\ 284.0 & 278.3 & 218.2 & 265.2 & 288.6 & 386.4 & 352.7 \\ 301.4 & 306.9 & 402.5 & 481.8 & 539.9 & 489.9 & 473.6 \\ 292.8 & 279.9 & 385.3 & 442.5 & 538.1 & 472.9 & 461.6\end{array}$


Republic of Congo: Basic Data 1997-2003 (continued)

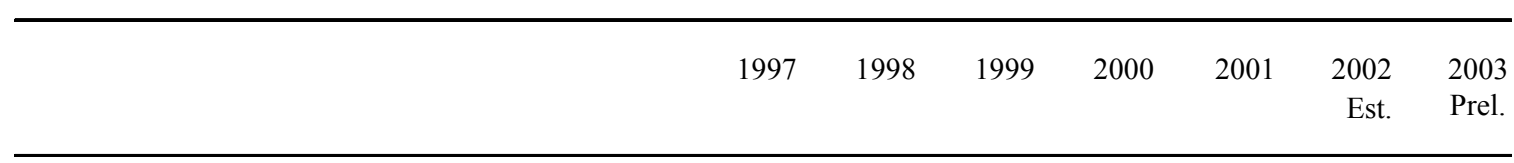

(In billions of CFA francs)

Central government operations

Revenue and grants
Revenue
Grants
Expenditure and net lending
Current
Capital

Overall balance (commitment basis)

Including grants

Excluding grants

Change in arrears

Financing

Foreign (net)

Domestic (net)

Banking system

Other

Revenue (excluding grants)

Grants

Total expenditure and net lending

Current expenditure

Capital expenditure

Overall balance (including grants)

Overall balance (excluding grants)

Money and credit 1/

Net foreign assets

Net domestic assets

Government (net)

Public agencies

Private sector and public enterprises

Other items (net)

Money and quasi money

$\begin{array}{rrrrrrr}387.7 & 263.0 & 390.6 & 609.4 & 631.8 & 575.4 & 613.5 \\ 386.3 & 259.4 & 384.3 & 602.6 & 628.1 & 571.7 & 603.6 \\ 1.4 & 3.6 & 6.3 & 6.8 & 3.7 & 3.7 & 9.9 \\ & & & & & & \\ 508.6 & 492.8 & 475.4 & 583.5 & 645.9 & 746.4 & 606.1 \\ 462.0 & 438.2 & 386.3 & 424.1 & 440.6 & 563.1 & 470.5 \\ 46.6 & 54.6 & 89.1 & 159.4 & 205.4 & 181.7 & 134.8 \\ & & & & & & \\ -121.0 & -229.8 & -84.8 & 25.9 & -14.1 & -171.0 & 7.4 \\ -122.4 & -233.4 & -91.1 & 19.1 & -17.8 & -174.6 & -2.5 \\ & & & & & & \\ -59.9 & 354.2 & 294.6 & 268.2 & 73.6 & 205.9 & 124.8 \\ & & & & & & \\ 180.9 & -124.4 & -209.8 & -294.0 & -59.5 & -34.9 & -132.1 \\ 149.7 & -152.7 & -177.1 & -239.4 & -85.0 & -15.0 & -146.1 \\ 31.2 & 28.3 & -32.7 & -54.6 & 25.5 & -19.9 & 14.0 \\ 31.7 & 12.4 & -21.9 & -13.9 & 75.1 & 23.2 & 1.0 \\ -0.5 & 15.9 & -10.8 & -40.7 & -49.5 & -43.1 & 13.0 \\ & & & & & & \\ & & (\text { In percent of GDP) } & & \\ 28.5 & 22.6 & 26.5 & 26.3 & 30.7 & 27.2 & 29.6 \\ 0.1 & 0.3 & 0.4 & 0.3 & 0.2 & 0.2 & 0.5 \\ 37.5 & 42.9 & 32.8 & 25.5 & 31.6 & 35.5 & 29.7 \\ 34.1 & 38.1 & 26.7 & 18.5 & 21.6 & 26.8 & 23.1 \\ 12.1 & 12.9 & 10.4 & 6.5 & 7.1 & 7.7 & 4.6 \\ -8.9 & -20.0 & -5.9 & 1.1 & -0.7 & -8.1 & 0.4 \\ -9.0 & -20.3 & -6.3 & 0.8 & -0.9 & -8.3 & -0.1 \\ & & & & & & \end{array}$

(In billions of CFA francs)

$\begin{array}{rrrrrrr}26.2 & -35.6 & 5.0 & 151.8 & 26.9 & 38.0 & 6.0 \\ 175.5 & 211.5 & 205.9 & 182.5 & 231.1 & 253.7 & 278.6 \\ 116.6 & 129.0 & 107.0 & 93.2 & 163.5 & 186.8 & 187.9 \\ -0.4 & -5.9 & -4.5 & 0.0 & -5.3 & -3.4 & -4.1 \\ 121.3 & 129.6 & 173.4 & 163.9 & 109.0 & 66.4 & 81.7 \\ -62.0 & -41.2 & -70.1 & -74.6 & -36.1 & 4.0 & 13.1 \\ 201.7 & 175.9 & 210.9 & 334.3 & 258.0 & 291.7 & 284.6\end{array}$


Republic of Congo: Basic Data, 1997-2003 (continued)

\begin{tabular}{|c|c|c|c|c|c|c|c|}
\hline & 1997 & 1998 & 1999 & 2000 & 2001 & $\begin{array}{r}2002 \\
\text { Est. }\end{array}$ & $\begin{array}{l}2003 \\
\text { Prel. }\end{array}$ \\
\hline & \multicolumn{7}{|c|}{ (In billions of CFA francs) } \\
\hline \multicolumn{8}{|l|}{ External sector } \\
\hline Trade balance & 588.4 & 478.5 & 636.2 & $1,319.7$ & $1,007.1$ & $1,075.1$ & $1,009.1$ \\
\hline Exports, f.o.b. & 967.1 & 808.0 & 958.0 & $1,743.8$ & $1,506.6$ & $1,567.3$ & $1,475.6$ \\
\hline Of which: oil sector & 769.6 & 708.2 & 879.6 & $1,633.2$ & $1,341.4$ & $1,373.8$ & $1,225.7$ \\
\hline Imports, f.o.b. & -378.7 & -329.4 & -321.8 & -424.1 & -499.5 & -492.2 & -466.4 \\
\hline Services, net & -378.7 & -436.4 & -444.9 & -478.5 & -462.8 & -514.0 & -494.9 \\
\hline Income & -386.1 & -277.3 & -436.5 & -672.6 & -611.3 & -570.7 & -508.8 \\
\hline Transfers, net & 1.2 & -1.8 & -3.3 & 13.4 & 2.3 & 2.7 & 3.8 \\
\hline Private & -2.4 & -6.3 & -3.6 & 5.0 & -1.9 & -1.7 & -0.6 \\
\hline Public grants & 3.6 & 4.5 & 0.4 & 8.4 & 4.2 & 4.4 & 4.3 \\
\hline \multicolumn{8}{|l|}{ Current account } \\
\hline Excluding public transfers & -178.8 & -241.6 & -248.8 & 173.6 & -68.8 & -11.3 & 4.9 \\
\hline Including public transfers & -175.3 & -237.0 & -248.4 & 182.0 & -64.6 & -6.9 & 9.2 \\
\hline Capital account & 211.4 & 31.3 & 14.9 & 14.3 & 69.2 & 10.7 & 11.1 \\
\hline Financial account & -34.3 & 253.7 & 256.7 & -35.1 & -107.2 & 36.1 & -1.3 \\
\hline Medium- and long-term capital & -73.7 & 139.5 & -343.7 & -116.4 & -206.5 & 107.3 & -70.1 \\
\hline $\begin{array}{l}\text { Short-term capital, including } \\
\text { errors and omissions }\end{array}$ & -15.2 & 3.2 & 305.4 & -300.3 & -57.2 & -301.9 & -128.6 \\
\hline Overall balance & -11.6 & -46.4 & 36.7 & 120.1 & -104.4 & -24.8 & 5.5 \\
\hline & \multicolumn{7}{|c|}{ (In percent of GDP, unless otherwise indicated) } \\
\hline \multicolumn{8}{|l|}{ Current account } \\
\hline Excluding public transfers & -13.2 & -21.0 & -17.2 & 7.6 & -3.4 & -0.5 & 0.2 \\
\hline Oil sector & 8.4 & 9.9 & 7.4 & 14.0 & 12.5 & 26.3 & 18.7 \\
\hline Non-oil sector & -21.4 & -30.4 & -24.3 & -6.7 & -15.8 & -26.8 & -18.4 \\
\hline Including public transfers & -12.9 & -20.6 & -17.1 & 7.9 & -3.2 & -0.3 & 0.4 \\
\hline Capital account & 15.6 & 2.7 & 1.0 & 0.6 & 3.4 & 0.5 & 0.5 \\
\hline Overall balance & -0.9 & -4.0 & 2.5 & 5.2 & -5.1 & -1.2 & 0.3 \\
\hline Gross reserves (in billions of CFA francs) & 37.8 & 2.3 & 27.8 & 158.6 & 53.6 & 22.2 & 20.5 \\
\hline In months of imports of goods & 0.6 & 0.0 & 0.4 & 1.9 & 0.6 & 0.2 & 0.2 \\
\hline \multicolumn{8}{|l|}{ External public debt } \\
\hline Including IMF & 220.0 & 264.4 & 231.6 & 163.2 & 196.3 & 179.1 & 184.7 \\
\hline Excluding IMF & 218.5 & 262.8 & 230.3 & 162.0 & 194.8 & 178.1 & 183.8 \\
\hline \multicolumn{8}{|l|}{ External public debt/exports } \\
\hline Including IMF & 290.9 & 346.6 & 320.3 & 203.3 & 245.1 & 222.1 & 234.3 \\
\hline Excluding IMF & 288.9 & 344.5 & 318.5 & 201.7 & 243.3 & 220.7 & 233.2 \\
\hline \multicolumn{8}{|l|}{ Debt service/exports } \\
\hline Before relief & 290.9 & 346.6 & 320.3 & 203.3 & 245.1 & 222.1 & 234.3 \\
\hline After relief & 288.9 & 344.5 & 318.5 & 201.7 & 243.3 & 220.7 & 233.2 \\
\hline \multicolumn{8}{|l|}{ Debt service payments/government receipts } \\
\hline Before relief & 106.3 & 163.2 & 107.3 & 73.4 & 60.4 & 68.0 & 44.7 \\
\hline After relief & 68.6 & 132.1 & 90.6 & 72.1 & 59.2 & 66.2 & 44.4 \\
\hline \multicolumn{8}{|l|}{ Debt service payments/non-oil GDP } \\
\hline Before relief & 59.6 & 58.0 & 61.0 & 56.0 & 42.9 & 39.8 & 26.0 \\
\hline After relief & 38.5 & 46.9 & 51.5 & 55.0 & 42.0 & 38.7 & 25.9 \\
\hline Net transfer of resources/GDP & 1.7 & -1.2 & -4.5 & -6.1 & -9.7 & -7.9 & -5.2 \\
\hline
\end{tabular}


Republic of Congo: Basic Data, 1997-2003 (concluded)

\begin{tabular}{|c|c|c|c|c|c|c|c|}
\hline & 1997 & 1998 & 1999 & 2000 & 2001 & $\begin{array}{r}2002 \\
\text { Est. }\end{array}$ & $\begin{array}{l}2003 \\
\text { Prel. }\end{array}$ \\
\hline Social indicators & \multicolumn{7}{|c|}{ (In percent, unless otherwise indicated) } \\
\hline Life expectancy at birth (years) & 50.9 & ... & $\ldots$ & 51.3 & 51.5 & $\ldots$ & $\ldots$ \\
\hline Fertility rate, total (births per woman) & 6.3 & $\ldots$ & $\ldots$ & 6.0 & 5.9 & $\ldots$ & $\ldots$ \\
\hline Infant mortality rate (per 1,000 live births) & 81.0 & $\ldots$ & $\ldots$ & 81.0 & 81.0 & $\ldots$ & $\ldots$ \\
\hline Mortality rate, under 5 (per 1,000 live births) & $\ldots$ & $\ldots$ & $\ldots$ & 108.0 & 108.0 & $\ldots$ & $\ldots$ \\
\hline Prevalence of HIV (female, percent ages 15-24) & $\cdots$ & $\cdots$ & $\cdots$ & $\cdots$ & 7.8 & $\cdots$ & ... \\
\hline \multicolumn{8}{|l|}{ Education (percent of people age $15+$ ) } \\
\hline Gross primary school enrollment rate & $\ldots$ & 57.3 & 83.8 & 96.9 & $\ldots$ & $\ldots$ & ... \\
\hline Of which: Female & $\ldots$ & 55.5 & $\ldots$ & $\ldots$ & $\ldots$ & $\cdots$ & ... \\
\hline Illiteracy rate & 23.0 & 21.8 & 20.5 & 19.3 & 18.2 & $\ldots$ & $\ldots$ \\
\hline Male & 15.5 & 14.6 & 13.5 & 12.5 & $\ldots$ & $\cdots$ & $\ldots$ \\
\hline Female & 30.1 & 28.6 & 27.0 & 25.6 & 24.1 & $\cdots$ & $\cdots$ \\
\hline \multicolumn{8}{|l|}{ Immunization rate (percent under 12 months) } \\
\hline Measles & 18.0 & 21.0 & 23.0 & 34.0 & 35.0 & $\ldots$ & ... \\
\hline Diphtheria & 23.0 & 26.0 & 29.0 & $\ldots$ & 31.0 & $\ldots$ & $\ldots$ \\
\hline
\end{tabular}

Sources: Ministry of Economy, Finance, and the Budget; World Bank, World Development Indicators; and staff estimates. 
Table 1. Republic of Congo: Gross Domestic Product at Constant 1990 Prices, 1997-2003

\begin{tabular}{|c|c|c|c|c|c|c|c|}
\hline & 1997 & 1998 & 1999 & 2000 & 2001 & $\begin{array}{r}2002 \\
\text { Est. }\end{array}$ & $\begin{array}{c}2003 \\
\text { Prel. }\end{array}$ \\
\hline & \multicolumn{5}{|c|}{ (In billions of CFA francs) } & & \\
\hline GDP at market prices & 807.5 & 837.6 & 812.5 & 879.4 & 910.7 & 942.5 & 951.8 \\
\hline Oil & 346.5 & 367.8 & 386.5 & 382.6 & 353.9 & 348.6 & 323.5 \\
\hline Non-oil & 461.0 & 469.8 & 426.0 & 496.8 & 556.8 & 593.9 & 628.2 \\
\hline GDP at factor cost & 789.5 & 811.3 & 792.2 & 850.0 & 871.3 & 905.3 & 913.4 \\
\hline Agriculture, livestock, and fishing & 73.1 & 73.1 & 69.0 & 71.9 & 75.8 & 79.1 & 84.1 \\
\hline Forestry & 16.1 & 17.6 & 15.8 & 17.5 & 19.9 & 21.8 & 22.3 \\
\hline Petroleum sector & 346.5 & 367.8 & 386.5 & 382.6 & 353.9 & 348.6 & 323.5 \\
\hline Industry and mines & 43.9 & 44.8 & 42.6 & 48.7 & 54.7 & 66.9 & 73.6 \\
\hline Electricity, gas, and water & 12.0 & 13.4 & 8.1 & 13.2 & 14.0 & 15.0 & 17.0 \\
\hline Construction and public works & 6.8 & 6.2 & 8.7 & 15.2 & 17.1 & 17.1 & 17.9 \\
\hline Commerce, restaurants, and hotels & 74.5 & 75.8 & 63.4 & 82.3 & 91.4 & 104.3 & 111.6 \\
\hline Transport and communication & 58.2 & 55.1 & 50.2 & 60.2 & 74.4 & 80.2 & 89.5 \\
\hline Public administration & 97.4 & 97.4 & 98.5 & 101.0 & 111.1 & 113.4 & 113.7 \\
\hline Other services & 61.0 & 60.1 & 49.4 & 57.4 & 59.0 & 58.9 & 60.3 \\
\hline \multirow[t]{2}{*}{ Import duties } & 18.0 & 26.3 & 20.3 & 29.4 & 39.4 & 37.2 & 38.4 \\
\hline & \multicolumn{5}{|c|}{ (In percent of GDP) } & & \\
\hline GDP at market prices & 100.0 & 100.0 & 100.0 & 100.0 & 100.0 & 100.0 & 100.0 \\
\hline Oil & 42.9 & 43.9 & 47.6 & 43.5 & 38.9 & 37.0 & 34.0 \\
\hline Non-oil & 57.1 & 56.1 & 52.4 & 56.5 & 61.1 & 63.0 & 66.0 \\
\hline GDP at factor cost & 97.8 & 96.9 & 97.5 & 96.7 & 95.7 & 96.1 & 96.0 \\
\hline Agriculture, livestock, and fishing & 9.1 & 8.7 & 8.5 & 8.2 & 8.3 & 8.4 & 8.8 \\
\hline Forestry & 2.0 & 2.1 & 1.9 & 2.0 & 2.2 & 2.3 & 2.3 \\
\hline Petroleum sector & 42.9 & 43.9 & 47.6 & 43.5 & 38.9 & 37.0 & 34.0 \\
\hline Industry and mines & 5.4 & 5.3 & 5.2 & 5.5 & 6.0 & 7.1 & 7.7 \\
\hline Electricity, gas, and water & 1.5 & 1.6 & 1.0 & 1.5 & 1.5 & 1.6 & 1.8 \\
\hline Construction and public works & 0.8 & 0.7 & 1.1 & 1.7 & 1.9 & 1.8 & 1.9 \\
\hline Commerce, restaurants, and hotels & 9.2 & 9.1 & 7.8 & 9.4 & 10.0 & 11.1 & 11.7 \\
\hline Transport and communication & 7.2 & 6.6 & 6.2 & 6.8 & 8.2 & 8.5 & 9.4 \\
\hline Public administration & 12.1 & 11.6 & 12.1 & 11.5 & 12.2 & 12.0 & 12.0 \\
\hline Other services & 7.6 & 7.2 & 6.1 & 6.5 & 6.5 & 6.2 & 6.3 \\
\hline Import duties & 2.2 & 3.1 & 2.5 & 3.3 & 4.3 & 3.9 & 4.0 \\
\hline
\end{tabular}

Sources: Ministry of Economy, Finance, and the Budget; and staff estimates. 
Table 2. Republic of Congo: Gross Domestic Product at Current Prices, 1997-2003

\begin{tabular}{|c|c|c|c|c|c|c|c|}
\hline & 1997 & 1998 & 1999 & 2000 & 2001 & $\begin{array}{r}2002 \\
\text { Est. }\end{array}$ & $\begin{array}{c}2003 \\
\text { Prel. }\end{array}$ \\
\hline & \multicolumn{6}{|c|}{ ( In billions of CFA francs) } & \\
\hline GDP at market prices & $1,355.7$ & $1,150.1$ & $1,449.3$ & $2,292.5$ & $2,043.4$ & $2,103.0$ & $2,040.0$ \\
\hline Oil & 666.7 & 419.6 & 773.3 & $1,502.3$ & $1,158.6$ & $1,126.4$ & $1,003.4$ \\
\hline Non-oil & 689.0 & 730.5 & 676.0 & 790.2 & 884.8 & 976.6 & $1,036.6$ \\
\hline GDP at factor cost & $1,325.5$ & $1,100.2$ & $1,412.9$ & $2,238.7$ & $1,966.5$ & $2,030.9$ & $1,963.7$ \\
\hline Agriculture, livestock, and fishing & 106.9 & 106.3 & 104.2 & 102.0 & 99.9 & 107.9 & 104.5 \\
\hline Forestry & 17.0 & 19.7 & 16.9 & 19.6 & 18.9 & 23.9 & 23.5 \\
\hline Petroleum sector & 666.7 & 419.6 & 773.3 & $1,502.3$ & $1,158.6$ & $1,126.4$ & $1,003.4$ \\
\hline Industry and mines & 74.0 & 80.0 & 79.2 & 79.7 & 90.6 & 110.1 & 131.9 \\
\hline Electricity, gas, and water & 13.6 & 14.9 & 9.3 & 15.6 & 16.0 & 18.5 & 19.7 \\
\hline Construction and public works & 16.6 & 15.2 & 26.2 & 56.5 & 74.4 & 75.9 & 89.4 \\
\hline Commerce, restaurants, and hotels & 132.9 & 139.3 & 116.7 & 138.5 & 139.9 & 167.6 & 180.6 \\
\hline Transport and communication & 77.5 & 77.7 & 72.0 & 86.0 & 110.8 & 123.4 & 137.4 \\
\hline Public administration & 122.0 & 119.2 & 122.1 & 125.1 & 137.3 & 147.9 & 148.4 \\
\hline Other services & 98.3 & 108.3 & 93.0 & 113.4 & 120.1 & 129.3 & 124.9 \\
\hline \multirow[t]{2}{*}{ Import duties } & 30.2 & 49.9 & 36.4 & 53.8 & 76.9 & 72.1 & 76.3 \\
\hline & \multicolumn{7}{|c|}{ (In percent of GDP) } \\
\hline GDP at market prices & 100.0 & 100.0 & 100.0 & 100.0 & 100.0 & 100.0 & 100.0 \\
\hline Oil & 49.2 & 36.5 & 53.4 & 65.5 & 56.7 & 53.6 & 49.2 \\
\hline Non-oil & 50.8 & 63.5 & 46.6 & 34.5 & 43.3 & 46.4 & 50.8 \\
\hline GDP at factor cost & 97.8 & 95.7 & 97.5 & 97.7 & 96.2 & 96.6 & 96.3 \\
\hline Agriculture, livestock, and fishing & 7.9 & 9.2 & 7.2 & 4.4 & 4.9 & 5.1 & 5.1 \\
\hline Forestry & 1.3 & 1.7 & 1.2 & 0.9 & 0.9 & 1.1 & 1.2 \\
\hline Petroleum sector & 49.2 & 36.5 & 53.4 & 65.5 & 56.7 & 53.6 & 49.2 \\
\hline Industry and mines & 5.5 & 7.0 & 5.5 & 3.5 & 4.4 & 5.2 & 6.5 \\
\hline Electricity, gas, and water & 1.0 & 1.3 & 0.6 & 0.7 & 0.8 & 0.9 & 1.0 \\
\hline Construction and public works & 1.2 & 1.3 & 1.8 & 2.5 & 3.6 & 3.6 & 4.4 \\
\hline Commerce, restaurants, and hotels & 9.8 & 12.1 & 8.1 & 6.0 & 6.8 & 8.0 & 8.9 \\
\hline Transport and communication & 5.7 & 6.8 & 5.0 & 3.8 & 5.4 & 5.9 & 6.7 \\
\hline Public administration & 9.0 & 10.4 & 8.4 & 5.5 & 6.7 & 7.0 & 7.3 \\
\hline Other services & 7.3 & 9.4 & 6.4 & 4.9 & 5.9 & 6.1 & 6.1 \\
\hline Import duties & 2.2 & 4.3 & 2.5 & 2.3 & 3.8 & 3.4 & 3.7 \\
\hline
\end{tabular}

Sources: Ministry of Economy, Finance, and the Budget; and staff estimates. 
Table 3. Republic of Congo: Supply and Use of Resources at

Constant 1990 Prices, 1997-2003

\begin{tabular}{|c|c|c|c|c|c|c|c|}
\hline & 1997 & 1998 & 1999 & 2000 & 2001 & $\begin{array}{r}2002 \\
\text { Est. }\end{array}$ & $\begin{array}{l}2003 \\
\text { Prel }\end{array}$ \\
\hline & \multicolumn{7}{|c|}{ (In billions of CFA francs) } \\
\hline Gross domestic product & 807.5 & 837.6 & 812.5 & 879.4 & 910.7 & 942.5 & 951.8 \\
\hline Imports of goods and services & 403.4 & 359.7 & 425.8 & 444.8 & 472.8 & 587.1 & 703.0 \\
\hline \multicolumn{8}{|l|}{ Total supply of resources } \\
\hline$=$ Total use of resources & $1,210.8$ & $1,197.4$ & $1,238.3$ & $1,324.2$ & $1,383.5$ & $1,529.6$ & $1,654.7$ \\
\hline Exports of goods and services & 528.4 & 636.9 & 536.0 & 543.2 & 553.6 & 612.9 & 588.3 \\
\hline Consumption & 534.2 & 428.3 & 521.6 & 581.2 & 617.7 & 663.4 & 763.0 \\
\hline Private & 394.7 & 286.0 & 423.6 & 471.2 & 504.3 & 479.6 & 598.5 \\
\hline Public & 139.6 & 142.3 & 98.0 & 110.0 & 113.4 & 183.8 & 164.5 \\
\hline Domestic investment & 148.2 & 132.2 & 180.7 & 199.8 & 212.2 & 253.4 & 303.5 \\
\hline Gross fixed capital formation & 143.9 & 120.5 & 173.0 & 183.5 & 211.5 & 244.6 & 295.8 \\
\hline Government & 22.9 & 23.5 & 40.0 & 66.1 & 80.7 & 94.0 & 86.4 \\
\hline Private & 121.0 & 97.0 & 133.0 & 117.4 & 130.8 & 150.6 & 209.4 \\
\hline Oil & 116.5 & 91.5 & 124.7 & 103.5 & 119.9 & 112.9 & 160.7 \\
\hline Non-oil & 5.3 & 5.5 & 20.4 & 20.9 & 21.9 & 37.7 & 48.7 \\
\hline \multirow[t]{2}{*}{ Variation in stocks } & 4.2 & 11.6 & 7.7 & 16.3 & 0.7 & 8.8 & 7.7 \\
\hline & \multicolumn{7}{|c|}{ (In percent of GDP) } \\
\hline Gross domestic product & 100.0 & 100.0 & 100.0 & 100.0 & 100.0 & 100.0 & 100.0 \\
\hline Imports of goods and services & 50.0 & 42.9 & 52.4 & 50.6 & 51.9 & 62.3 & 73.5 \\
\hline \multicolumn{8}{|l|}{ Total supply of resources } \\
\hline$=$ Total use of resources & 150.0 & 142.9 & 152.4 & 150.6 & 151.9 & 162.3 & 173.9 \\
\hline Exports of goods and services & 65.4 & 76.0 & 66.0 & 61.8 & 60.8 & 65.0 & 61.8 \\
\hline Consumption & 66.2 & 51.1 & 64.2 & 66.1 & 67.8 & 70.4 & 80.2 \\
\hline Private & 48.9 & 34.1 & 12.1 & 12.5 & 12.5 & 50.9 & 62.9 \\
\hline Public & 17.3 & 17.0 & 52.1 & 53.6 & 55.4 & 19.5 & 17.3 \\
\hline Domestic investment & 18.3 & 15.8 & 22.2 & 22.7 & 23.3 & 26.9 & 31.9 \\
\hline Gross fixed capital formation & 17.8 & 14.4 & 21.3 & 20.9 & 23.2 & 25.9 & 31.1 \\
\hline Government & 2.8 & 2.8 & 4.9 & 7.5 & 8.9 & 10.0 & 9.1 \\
\hline Private & 15.0 & 11.6 & 16.4 & 13.3 & 14.4 & 16.0 & 22.0 \\
\hline Oil & 14.4 & 10.9 & 15.3 & 11.8 & 13.2 & 12.0 & 16.9 \\
\hline Non-oil & 0.7 & 0.7 & 2.5 & 2.4 & 2.4 & 4.0 & 5.1 \\
\hline Variation in stocks & 0.5 & 1.4 & 1.0 & 1.9 & 0.1 & 0.9 & 0.8 \\
\hline
\end{tabular}

Sources: Ministry of Economy, Finance, and the Budget; and staff estimates. 
Table 4. Republic of Congo: Supply and Use of Resources

at Current Prices, 1997-2003

\begin{tabular}{|c|c|c|c|c|c|c|c|}
\hline & 1997 & 1998 & 1999 & 2000 & 2001 & $\begin{array}{r}2002 \\
\text { Est. }\end{array}$ & $\begin{array}{l}2003 \\
\text { Prel. }\end{array}$ \\
\hline & \multicolumn{7}{|c|}{ (In billions of CFA francs) } \\
\hline Gross domestic product & $1,355.7$ & $1,150.1$ & $1,449.3$ & $2,292.5$ & $2,043.4$ & $2,103.0$ & $2,040.0$ \\
\hline Imports of goods and services & 815.6 & 835.3 & 856.6 & 999.8 & $1,092.0$ & $1,135.4$ & $1,097.0$ \\
\hline \multicolumn{8}{|l|}{ Total supply of resources } \\
\hline$=$ Total use of resources & $2,171.3$ & $1,985.4$ & $2,305.9$ & $3,292.3$ & $3,135.4$ & $3,238.4$ & $3,137.0$ \\
\hline Exports of goods and services & $1,025.2$ & 877.4 & $1,047.9$ & $1,841.0$ & $1,636.3$ & $1,696.4$ & $1,608.0$ \\
\hline Consumption & 844.6 & 801.1 & 855.5 & 969.5 & 959.242 & $1,052.0$ & $1,055.4$ \\
\hline Private & 560.6 & 522.8 & 637.2 & 704.3 & 670.642 & 665.6 & 702.7 \\
\hline Public & 284.0 & 278.3 & 218.2 & 265.2 & 288.6 & 386.4 & 352.7 \\
\hline Domestic investment & 301.4 & 306.9 & 402.5 & 481.8 & 539.9 & 489.9 & 473.6 \\
\hline Gross fixed capital formation & 292.8 & 279.9 & 385.3 & 442.5 & 538.063 & 472.9 & 461.6 \\
\hline Government & 46.6 & 54.6 & 89.1 & 159.4 & 205.363 & 181.7 & 134.8 \\
\hline Private & 246.2 & 225.3 & 296.2 & 283.1 & 332.7 & 291.2 & 326.8 \\
\hline Oil & 235.5 & 212.5 & 250.8 & 232.7 & 276.9 & 218.3 & 250.8 \\
\hline Non-oil & 10.7 & 12.8 & 45.4 & 50.4 & 55.8 & 72.9 & 76.0 \\
\hline \multirow[t]{2}{*}{ Variation in stocks } & 8.6 & 27.0 & 17.2 & 39.3 & 1.8 & 17.0 & 12.0 \\
\hline & \multicolumn{7}{|c|}{ (In percent of GDP) } \\
\hline Gross domestic product & 100.0 & 100.0 & 100.0 & 100.0 & 100.0 & 100.0 & 100.0 \\
\hline Imports of goods and services & 60.2 & 72.6 & 59.1 & 43.6 & 53.4 & 54.0 & 53.8 \\
\hline \multicolumn{8}{|l|}{ Total supply of resources } \\
\hline$=$ Total use of resources & 159.3 & 182.7 & 154.2 & 140.3 & 149.1 & 150.1 & 151.1 \\
\hline Exports of goods and services & 75.6 & 76.3 & 72.3 & 80.3 & 80.1 & 80.7 & 78.8 \\
\hline Consumption & 62.3 & 69.7 & 59.0 & 42.3 & 46.9 & 50.0 & 51.7 \\
\hline Private & 41.4 & 45.5 & 15.1 & 11.6 & 14.1 & 18.4 & 17.3 \\
\hline Public & 20.9 & 24.2 & 44.0 & 30.7 & 32.8 & 31.6 & 34.4 \\
\hline Domestic investment & 22.2 & 26.7 & 27.8 & 21.0 & 26.4 & 23.3 & 23.2 \\
\hline Gross fixed capital formation & 21.6 & 24.3 & 26.6 & 19.3 & 26.3 & 22.5 & 22.6 \\
\hline Government & 3.4 & 4.7 & 6.1 & 7.0 & 10.1 & 8.6 & 6.6 \\
\hline Private & 18.2 & 19.6 & 20.4 & 12.3 & 16.3 & 13.8 & 16.0 \\
\hline Oil & 17.4 & 18.5 & 17.3 & 10.2 & 13.6 & 10.4 & 12.3 \\
\hline Non-oil & 0.8 & 1.1 & 3.1 & 2.2 & 2.7 & 3.5 & 3.7 \\
\hline Variation in stocks & 0.6 & 2.3 & 1.2 & 1.7 & 0.1 & 0.8 & 0.6 \\
\hline
\end{tabular}

Sources: Ministry of Economy, Finance, and the Budget; and staff estimates. 
Table 5. Republic of Congo: Saving and Investment Balances, 1996-2003 1/

(In percent of GDP, unless otherwise indicated)

\begin{tabular}{|c|c|c|c|c|c|c|c|}
\hline & 1997 & 1998 & 1999 & 2000 & 2001 & $\begin{array}{r}2002 \\
\text { Est. }\end{array}$ & $\begin{array}{r}2003 \\
\text { Prel. }\end{array}$ \\
\hline \multicolumn{8}{|l|}{ Total economy } \\
\hline Gross national saving & 9.3 & 6.1 & 10.6 & 29.0 & 23.3 & 23.0 & 23.6 \\
\hline Gross domestic saving & 37.7 & 30.3 & 41.0 & 57.7 & 53.1 & 50.0 & 48.3 \\
\hline Investment & 22.2 & 26.7 & 27.8 & 21.0 & 26.4 & 23.3 & 23.2 \\
\hline \multicolumn{8}{|l|}{ Net domestic financial balance } \\
\hline \multicolumn{8}{|l|}{ Net financial balance (external current } \\
\hline Excluding official transfers & $\begin{array}{r}-12.9 \\
-13.2\end{array}$ & -21.0 & -17.2 & 7.6 & -3.4 & $\begin{array}{l}-0.5 \\
-0.5\end{array}$ & $\begin{array}{l}0.4 \\
0.2\end{array}$ \\
\hline \multicolumn{8}{|l|}{ Government } \\
\hline Gross national saving & -4.1 & -13.6 & 1.9 & 9.2 & 10.1 & 3.5 & 9.2 \\
\hline Gross domestic saving & 7.8 & -1.0 & 12.3 & 15.3 & 17.0 & 9.2 & 13.3 \\
\hline Investment & 3.4 & 4.7 & 6.1 & 7.0 & 10.1 & 8.6 & 6.6 \\
\hline Net domestic financial balance & 4.3 & -5.8 & 6.2 & 8.4 & 6.9 & 0.5 & 6.7 \\
\hline Net financial balance & -7.5 & -18.3 & -4.2 & 2.2 & 0.0 & -5.1 & 2.5 \\
\hline Excluding official transfers & -4.4 & -14.0 & 1.9 & 8.8 & 9.9 & 3.3 & 8.9 \\
\hline \multicolumn{8}{|l|}{ Private sector $2 /$} \\
\hline Gross national saving & 13.4 & 19.6 & 8.7 & 19.8 & 13.2 & 19.5 & 14.4 \\
\hline Gross domestic saving & 29.9 & 31.4 & 28.6 & 42.4 & 36.1 & 40.8 & 35.0 \\
\hline Investment & 18.8 & 21.9 & 21.6 & 14.1 & 16.4 & 14.7 & 16.6 \\
\hline Net domestic financial balance & 11.2 & 9.4 & 7.0 & 28.3 & 19.7 & 26.2 & 18.4 \\
\hline Net financial balance & -5.4 & -2.3 & -12.9 & 5.7 & -3.2 & 4.8 & -2.2 \\
\hline \multicolumn{8}{|l|}{ Oil sector } \\
\hline Gross national saving & 2.5 & 11.4 & 4.8 & -6.9 & 6.2 & 20.1 & 16.6 \\
\hline Gross domestic saving 3/ & 23.7 & 19.6 & 28.0 & 30.6 & 33.0 & 39.0 & 36.7 \\
\hline Investment & 17.4 & 18.5 & 17.3 & 10.2 & 13.6 & 10.4 & 12.3 \\
\hline Net domestic financial balance & 6.3 & 1.1 & 10.7 & 20.4 & 19.4 & 28.6 & 24.4 \\
\hline Net financial balance & -14.9 & -7.1 & -12.5 & -17.1 & -7.4 & 9.7 & 4.3 \\
\hline \multicolumn{8}{|l|}{ Non-oil sector } \\
\hline Gross national saving & 10.9 & 8.3 & 3.9 & 26.7 & 7.0 & -0.7 & -2.2 \\
\hline Gross domestic saving 3/ & 6.2 & 11.8 & 0.7 & 11.8 & 3.1 & 1.8 & -1.7 \\
\hline Investment & 1.4 & 3.5 & 4.3 & 3.9 & 2.8 & 4.3 & 4.3 \\
\hline Net domestic financial balance & 4.8 & 8.3 & -3.7 & 7.9 & 0.3 & -2.5 & -6.0 \\
\hline Net financial balance & 9.5 & 4.8 & -0.4 & 22.8 & 4.2 & -4.9 & -6.5 \\
\hline \multicolumn{8}{|l|}{ Memorandum items: } \\
\hline \multicolumn{8}{|l|}{ Private consumption } \\
\hline As a percent of total GDP & 41.4 & 45.5 & 44.0 & 30.7 & 32.8 & 31.6 & 34.4 \\
\hline As a percent of non-oil GDP & 81.4 & 71.6 & 94.3 & 89.1 & 75.8 & 68.2 & 67.8 \\
\hline
\end{tabular}

Sources: Ministry of Economy, Finance, and the Budget; and staff estimates.

1/ Data subject to a large degree of uncertainty; balance of payments being rebuilt.

2/ Including public enterprises.

3/ Owing to data limitations, the split between the saving of the oil and non-oil private sectors is subject to uncertainty. 
Table 6. Republic of Congo: Production of Principal Crops, 1996/97-2002/03

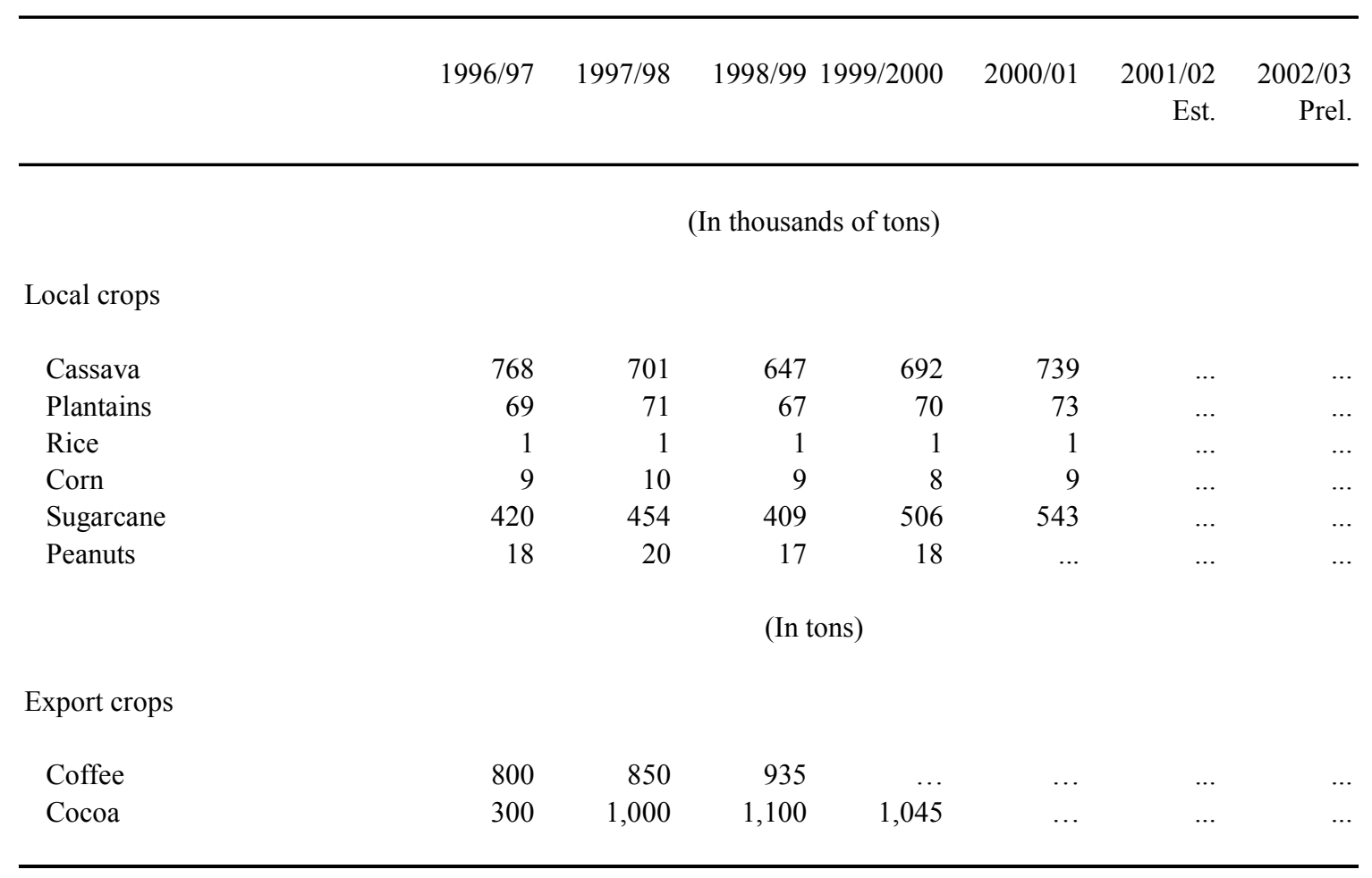

Source: National Center of Statistics and Economic Research (CNSEE). 
Table 7. Republic of Congo: Fishing Production, 1997-2003

(In tons)

\begin{tabular}{lrrrrrrr}
\hline & 1997 & 1998 & 1999 & 2000 & $\begin{array}{r}2001 \\
\text { Est. }\end{array}$ & $\begin{array}{r}2002 \\
\text { Est. }\end{array}$ & $\begin{array}{r}2003 \\
\text { Est. }\end{array}$ \\
& & & & & & & \\
& & & & & & & \\
Total & 29,765 & 30,144 & 31,789 & 32,893 & 35,488 & $\ldots$ & $\ldots$ \\
Industrial & 17,365 & 17,000 & 17,659 & 17,350 & 18,391 & $\ldots$ & $\ldots$ \\
Artisanal & 12,400 & 13,144 & 14,130 & 15,543 & 17,097 & $\ldots$ & $\ldots$ \\
\hline
\end{tabular}

Source: National Center of Statistics and Economic Research (CNSEE). 
Table 8. Republic of Congo: Wood Production, 1997-2003

(In thousands of cubic meters)

\begin{tabular}{|c|c|c|c|c|c|c|c|}
\hline & 1997 & 1998 & 1999 & 2000 & 2001 & $\begin{array}{r}2002 \\
\text { Est. }\end{array}$ & $\begin{array}{c}2003 \\
\text { Prel. }\end{array}$ \\
\hline Timber production & 685.1 & 741.1 & 530.0 & 631.0 & 883.0 & $\ldots$ & $\ldots$ \\
\hline Eucalyptus log production & 362.9 & 486.1 & 631.4 & 545.0 & 233.0 & $\ldots$ & $\ldots$ \\
\hline \multicolumn{8}{|l|}{ Exports } \\
\hline Logs & 325.5 & 313.7 & 219.2 & 281.6 & 464.4 & $\ldots$ & $\ldots$ \\
\hline Other & 343.8 & 402.9 & 552.2 & 485.8 & 331.0 & $\ldots$ & $\ldots$ \\
\hline Sawn timber and veneer & 102.1 & 109.0 & 81.2 & 69.0 & 94.1 & $\ldots$ & $\ldots$ \\
\hline Wood transformation & 126.3 & 137.3 & 100.3 & 105.0 & 142.5 & $\ldots$ & $\ldots$ \\
\hline Sawn timber & 77.9 & 88.0 & 77.3 & 95.5 & 127.0 & $\ldots$ & $\ldots$ \\
\hline Peeled veneer & 40.5 & 40.7 & 20.0 & 8.2 & 14.2 & $\ldots$ & $\ldots$ \\
\hline Cut veneer & 3.5 & 2.8 & 0.0 & 0.0 & 0.0 & $\ldots$ & $\ldots$ \\
\hline Plywood & 4.4 & 5.8 & 3.0 & 1.3 & 1.3 & $\ldots$ & $\ldots$ \\
\hline
\end{tabular}

Source: Ministry of Forestry and Fisheries. 
Table 9. Republic of Congo: Oil Production by Field, 1997-2003

(In thousands of tons)

\begin{tabular}{|c|c|c|c|c|c|c|c|}
\hline & 1997 & 1998 & 1999 & 2000 & 2001 & $\begin{array}{r}2002 \\
\text { Est. }\end{array}$ & $\begin{array}{c}2003 \\
\text { Prel. }\end{array}$ \\
\hline Total liquids & $11,412.0$ & $13,092.5$ & $13,363.7$ & $13,774.1$ & $12,123.4$ & $11,937.2$ & $11,163.2$ \\
\hline Crude oil & $11,412.0$ & $12,747.5$ & $12,968.1$ & $13,397.7$ & $11,764.4$ & $11,584.5$ & $10,897.2$ \\
\hline Emeraude & 440.7 & 419.8 & 421.1 & 309.9 & 233.4 & 238.1 & 289.7 \\
\hline Likouala & 366.7 & 380.1 & 384.4 & 868.6 & 270.7 & 269.3 & 250.5 \\
\hline Yanga & 463.5 & 454.3 & 446.3 & 407.1 & 364.4 & 287.9 & 294.9 \\
\hline Sendji & 628.8 & 730.8 & 727.4 & 715.7 & 735.8 & 713.5 & 758.6 \\
\hline Tchibouéla & $1,966.7$ & $1,711.8$ & $1,583.3$ & $1,536.3$ & $1,564.6$ & $1,543.2$ & $1,304.0$ \\
\hline Tchendo & 420.6 & 346.3 & 315.5 & 338.4 & 269.4 & 327.3 & 357.1 \\
\hline Tchibouéla Est & 0.0 & 293.1 & 343.3 & 262.1 & 213.8 & 216.2 & 176.3 \\
\hline Kombi & 0.0 & 0.0 & 116.9 & 581.8 & 391.2 & 392.3 & 438.7 \\
\hline Likalala & 0.0 & 0.0 & 69.9 & 525.5 & 510.7 & 456.8 & 451.5 \\
\hline Tchibéli & 0.0 & 0.0 & 0.0 & 310.6 & 449.9 & 486.7 & 345.7 \\
\hline Likouala Est & 0.0 & 0.0 & 0.0 & 0.0 & 96.1 & 124.2 & 78.9 \\
\hline Nkossa Huile & $3,346.9$ & $2,450.7$ & $2,974.8$ & $2,618.3$ & $2,124.3$ & $1,651.5$ & $1,299.3$ \\
\hline Loango & $1,400.0$ & $1,479.5$ & $1,387.6$ & $1,267.4$ & $1,160.8$ & $1,130.3$ & $1,103.2$ \\
\hline Zatchi & $1,636.8$ & $1,634.8$ & $1,574.3$ & $1,456.2$ & $1,382.3$ & $1,278.7$ & $1,257.0$ \\
\hline Mwafi & 0.0 & 0.0 & 0.0 & 0.0 & 60.8 & 367.8 & 311.7 \\
\hline Kitina & 17.1 & $2,030.6$ & $1,744.5$ & $1,323.6$ & 874.1 & 619.4 & 637.1 \\
\hline Djambala & 0.0 & 0.0 & 115.2 & 72.3 & 55.8 & 203.4 & 134.5 \\
\hline Foukanda & 0.0 & 0.0 & 0.0 & 0.0 & 155.4 & 380.7 & 390.8 \\
\hline Yombo & 718.6 & 809.8 & 758.7 & 781.5 & 788.4 & 768.1 & 726.3 \\
\hline Pointe Indienne & 5.7 & 5.8 & 5.0 & 6.0 & 5.7 & 7.0 & 5.5 \\
\hline Kouak/Mboudi & 0.0 & 0.0 & 0.0 & 16.4 & 57.0 & 122.2 & 285.8 \\
\hline Refined products & 0.0 & 345.0 & 395.6 & 376.4 & 359.1 & 352.7 & 266.1 \\
\hline Nkossa Butane & 0.0 & 149.1 & 165.5 & 153.9 & 145.9 & 147.2 & 105.2 \\
\hline Nkossa Propane & 0.0 & 196.0 & 230.1 & 222.5 & 213.1 & 205.5 & 160.9 \\
\hline
\end{tabular}

Source: Ministry of Hydrocarbons. 
Table 10. Republic of Congo: Oil Refinery Production, 1997-2003 1/

(In thousands of metric tons)

\begin{tabular}{|c|c|c|c|c|c|c|c|}
\hline & 1997 & 1998 & 1999 & 2000 & 2001 & $\begin{array}{c}2002 \\
\text { Est. }\end{array}$ & $\begin{array}{c}2003 \\
\text { Prel. }\end{array}$ \\
\hline Butane & 1.1 & 0.2 & 0.3 & 0.2 & 0.2 & 0.2 & $\ldots$ \\
\hline Kerosene & 18.9 & 0.2 & 0.3 & 0.2 & 0.2 & 0.2 & $\ldots$ \\
\hline Diesel & 31.1 & 0.0 & 0.0 & 74.0 & 69.9 & $\ldots$ & $\ldots$ \\
\hline Premium & 20.5 & 0.0 & 0.0 & 35.0 & 38.7 & $\ldots$ & $\ldots$ \\
\hline Fuel oil 1,500 & 8.2 & 0.0 & 0.0 & 3.3 & 5.3 & $\ldots$ & $\ldots$ \\
\hline Fuel oil V. 630 & 100.7 & 0.0 & 0.0 & 208.0 & 225.7 & $\ldots$ & $\ldots$ \\
\hline Total & 180.5 & 0.5 & 0.5 & 320.8 & 340.0 & 0.4 & $\ldots$ \\
\hline
\end{tabular}

Source: Ministry of Hydrocarbons.

1/ Refinery suspended operations from end-1997 until March 2000. 
Table 11. Republic of Congo: Consumption of Refined

Petroleum Products, 1997-2003

(In thousands of metric tons)

\begin{tabular}{|c|c|c|c|c|c|c|c|}
\hline & 1997 & 1998 & 1999 & 2000 & 2001 & $\begin{array}{r}2002 \\
\text { Est. }\end{array}$ & $\begin{array}{c}2003 \\
\text { Prel. }\end{array}$ \\
\hline Butane & 1.1 & 1.6 & 0.5 & 1.0 & 2.1 & $\ldots$ & $\ldots$ \\
\hline Jet fuel & 18.9 & 22.8 & 32.8 & 50.0 & 51.3 & $\ldots$ & $\ldots$ \\
\hline Premium gasoline & 20.6 & 28.9 & 22.7 & 38.8 & 39.1 & $\ldots$ & $\ldots$ \\
\hline Diesel & 31.2 & 54.1 & 46.9 & 57.0 & 64.6 & $\ldots$ & $\ldots$ \\
\hline Kerosene & 9.6 & 12.3 & 4.8 & 7.5 & 8.3 & $\ldots$ & $\ldots$ \\
\hline Heating oil & $\ldots$ & 1.1 & $\ldots$ & $\ldots$ & $\ldots$ & $\ldots$ & $\ldots$ \\
\hline Total & 81.4 & 120.8 & 107.7 & 154.3 & 165.4 & $\ldots$ & $\ldots$ \\
\hline
\end{tabular}

Source: Ministry of Hydrocarbons. 
Table 12. Republic of Congo: Industrial Production, 1997-2003

(In tons, unless otherwise indicated)

\begin{tabular}{|c|c|c|c|c|c|c|c|}
\hline & 1997 & 1998 & 1999 & 2000 & 2001 & $\begin{array}{r}2002 \\
\text { Est. }\end{array}$ & $\begin{array}{l}2003 \\
\text { Prel. }\end{array}$ \\
\hline Cement & 20,156 & $\ldots$ & $\ldots$ & $\ldots$ & $\ldots$ & $\ldots$ & $\ldots$ \\
\hline Refined sugar & 38,774 & 42,861 & 39,772 & 74,626 & 71,814 & $\ldots$ & $\ldots$ \\
\hline Palm oil & $\ldots$ & $\ldots$ & 10,230 & $\ldots$ & $\ldots$ & $\ldots$ & $\ldots$ \\
\hline Peanut oil & $\ldots$ & $\ldots$ & $\ldots$ & $\ldots$ & $\ldots$ & $\ldots$ & $\ldots$ \\
\hline Soap & 1,683 & 1,733 & 1,473 & 1,620 & $\ldots$ & $\ldots$ & $\ldots$ \\
\hline Cloth (millions of meters) & $\ldots$ & $\ldots$ & $\ldots$ & $\ldots$ & $\cdots$ & $\cdots$ & $\cdots$ \\
\hline Cigarettes (millions of cartons) & 380 & $\ldots$ & $\ldots$ & $\ldots$ & 4 & $\ldots$ & $\ldots$ \\
\hline Beer (thousands of hectoliters) & 342 & 494 & 480 & 526 & 610 & $\ldots$ & $\ldots$ \\
\hline $\begin{array}{l}\text { Nonalcoholic beverages } \\
\text { (thousands of hectoliters) }\end{array}$ & 165 & 195 & 194 & 290 & 349 & $\ldots$ & $\ldots$ \\
\hline Flour & 8,177 & 4,002 & $\ldots$ & 1,636 & 35,000 & $\cdots$ & ... \\
\hline Electricity (millions of kilowatt-hours) & 366 & 408 & 196 & 298 & 339 & $\ldots$ & $\ldots$ \\
\hline
\end{tabular}

Source: National Center of Statistics and Economic Research (CNSEE). 
Table 13. Republic of Congo: Electricity Generation, 1997-2003

(In millions of kilowatt-hours)

\begin{tabular}{|c|c|c|c|c|c|c|c|}
\hline & 1997 & 1998 & 1999 & 2000 & 2001 & $\begin{array}{c}2002 \\
\text { Est. }\end{array}$ & $\begin{array}{l}2003 \\
\text { Prel. }\end{array}$ \\
\hline National production & 366.0 & 408.0 & 196.0 & 298.0 & 335.0 & 398.0 & 399.0 \\
\hline Hydroelectric & 366.0 & 408.0 & 196.0 & 298.0 & 339.0 & $\ldots$ & 342.0 \\
\hline Thermal & $\ldots$ & $\ldots$ & 16.0 & 0.9 & 0.1 & 0.1 & 57.0 \\
\hline $\begin{array}{l}\text { Purchases from the I } \\
\text { of the Congo }\end{array}$ & 37.6 & 126.7 & 191.0 & 262.0 & 297.0 & 364.0 & 359.0 \\
\hline Total & 403.6 & 534.7 & 387.0 & $\ldots$ & 632.0 & 762.0 & 758.0 \\
\hline
\end{tabular}

Source: National Electricity Company. 
Table 14. Republic of Congo: Rail and River Traffic, 1997-2003

\begin{tabular}{|c|c|c|c|c|c|c|c|}
\hline & 1997 & 1998 & 1999 & 2000 & 2001 & $\begin{array}{c}2002 \\
\text { Est. }\end{array}$ & $\begin{array}{c}2003 \\
\text { Prel. }\end{array}$ \\
\hline \multicolumn{8}{|l|}{ Rail transport } \\
\hline Passengers (thousands of persons) & $1,040.8$ & 926.6 & 56.5 & 546.0 & 742.0 & $\ldots$ & $\ldots$ \\
\hline Freight (thousands of tons) & 441.3 & 398.7 & 65.7 & 236.0 & 548.0 & $\ldots$ & $\ldots$ \\
\hline \multicolumn{8}{|l|}{ Port activity $1 /$} \\
\hline Pointe-Noire (thousands of tons) 2/ & $\ldots$ & $9,501.0$ & $9,438.0$ & $10,101.0$ & $9,608.0$ & $\ldots$ & $\ldots$ \\
\hline River ports (thousands of tons) & $\ldots$ & $\ldots$ & 105.7 & 74.6 & 101.2 & $\ldots$ & $\ldots$ \\
\hline \multicolumn{8}{|l|}{ River transport $1 /$} \\
\hline Barges (thousands of tons) & $\ldots$ & $\ldots$ & $\ldots$ & $\ldots$ & $\ldots$ & $\ldots$ & $\ldots$ \\
\hline Rafts (thousands of tons) & $\ldots$ & $\ldots$ & $\ldots$ & $\ldots$ & $\ldots$ & $\ldots$ & $\ldots$ \\
\hline Passengers (thousands) & $\ldots$ & $\ldots$ & 47.7 & 198.8 & 213.8 & $\ldots$ & $\ldots$ \\
\hline
\end{tabular}

Source: Ministry of Transport and Civil Aviation.

1/ No consistent data are available.

2/ Oil export included. 
Table 15. Republic of Congo: Price Indices for Brazzaville, 1997-2003

(Index, 1977=100, unless otherwise indicated)

\begin{tabular}{|c|c|c|c|c|c|c|c|}
\hline & 1997 & 1998 & 1999 & 2000 & 2001 & $\begin{array}{r}2002 \\
\text { Est. }\end{array}$ & $\begin{array}{c}2003 \\
\text { Prel. }\end{array}$ \\
\hline Foodstuffs & 378.4 & 376.8 & 394.8 & 374.3 & 368.0 & 385.3 & 362.8 \\
\hline Clothing & 436.0 & 419.1 & 433.4 & 459.7 & 465.2 & 488.6 & 439.1 \\
\hline Beverages and tobacco & 743.4 & 456.8 & 454.4 & 456.0 & 458.7 & 342.4 & 448.7 \\
\hline Construction and rent & 541.8 & 537.0 & 543.5 & 587.4 & 551.8 & 562.2 & 567.1 \\
\hline Fuel and electricity & 326.2 & 353.2 & 375.0 & 387.9 & 513.8 & 502.5 & 470.6 \\
\hline Health & 324.3 & 348.8 & 374.4 & 400.1 & 405.1 & 444.1 & 428.2 \\
\hline Transportation and leisure & 650.5 & 547.4 & 581.3 & 609.0 & 623.4 & 696.5 & 788.0 \\
\hline Other & 352.5 & 350.4 & 345.7 & 351.9 & 352.7 & 379.9 & 386.5 \\
\hline General index 1/ & 420.3 & 403.7 & 420.4 & 416.7 & 417.0 & 435.2 & 432.5 \\
\hline Percentage change from previous year & 19.1 & -3.9 & 4.1 & -0.9 & 0.1 & 4.4 & -0.6 \\
\hline
\end{tabular}

Source: National Center of Statistics and Economic Research (CNSEE).

1/ Brazzaville consumer price index only; therefore data differ from the aggregate consumer price index for Brazzaville and Pointe-Noire included in the basic data table. 
Table 16. Republic of Congo: Representative Retail Prices of Major Food Items in Brazzaville, 1997-2003

(CFA francs per kilogram, unless otherwise indicated; end of period)

\begin{tabular}{|c|c|c|c|c|c|c|c|}
\hline & 1997 & 1998 & 1999 & 2000 & 2001 & $\begin{array}{r}2002 \\
\text { Est. }\end{array}$ & $\begin{array}{c}2003 \\
\text { Prel. }\end{array}$ \\
\hline Manioc flour & 275 & 320 & 379 & 291 & 338 & 376 & 312 \\
\hline Corn & 392 & 533 & 598 & 622 & 558 & 557 & 684 \\
\hline Yams & 276 & 304 & 353 & 303 & 289 & 392 & 361 \\
\hline Sweet potatoes & 603 & 974 & 809 & 656 & 673 & 827 & 781 \\
\hline Sweet bananas & 380 & 349 & 571 & 413 & 349 & 425 & 414 \\
\hline Palm kernels & 253 & 270 & 387 & 169 & 164 & 225 & 177 \\
\hline Palm oil (per liter) & 564 & 615 & 715 & 476 & 523 & 606 & 578 \\
\hline Peanut oil (per liter) & 1,099 & 982 & 922 & 784 & 762 & 869 & 788 \\
\hline Shelled peanuts & 711 & 787 & 861 & 891 & 712 & 651 & 684 \\
\hline Salt & 372 & 414 & 487 & 513 & 352 & 321 & 352 \\
\hline Beef, boneless & 2,543 & 2,843 & 2,816 & 2,994 & 3,058 & 3,036 & 3,046 \\
\hline Chicken & 2,129 & 2,248 & 2,192 & 2,409 & 2,388 & 2,466 & 2,345 \\
\hline Fresh fish (river) & 1,296 & 1,412 & 1,318 & 1,267 & 1,258 & 1,350 & 1,445 \\
\hline Smoked fish & 4,521 & 3,880 & 3,590 & 3,556 & 3,982 & 4,015 & 4,083 \\
\hline
\end{tabular}

Source: National Center of Statistics and Economic Research (CNSEE). 
Table 17. Republic of Congo: Central Government Employment by Ministry, 1997-2003

(Number of employees)

\begin{tabular}{|c|c|c|c|c|c|c|c|}
\hline & 1997 & 1998 & 1999 & 2000 & 2001 & $\begin{array}{r}2002 \\
\text { Est. }\end{array}$ & $\begin{array}{c}2003 \\
\text { Prel. }\end{array}$ \\
\hline Education & 21,667 & 21,070 & 20,382 & 22,619 & 22,050 & 21,825 & 21,413 \\
\hline Health and social affairs & 8,922 & 8,676 & 8,392 & 9,313 & 9,079 & 8,986 & 8,817 \\
\hline Rural economy & 3,796 & 3,692 & 3,571 & 3,963 & 3,863 & 3,824 & 3,752 \\
\hline Finance & 4,149 & 4,034 & 3,903 & 4,331 & 4,222 & 4,179 & 4,100 \\
\hline Interior & 1,522 & 1,480 & 1,432 & 1,589 & 1,549 & 1,533 & 1,504 \\
\hline Culture and sports & 1,874 & 1,822 & 1,763 & 1,956 & 1,907 & 1,887 & 1,852 \\
\hline Information & 1,382 & 1,344 & 1,300 & 1,443 & 1,407 & 1,392 & 1,366 \\
\hline Presidency & 1,200 & 1,167 & 1,129 & 1,253 & 1,221 & 1,209 & 1,186 \\
\hline Justice & 843 & 820 & 793 & 880 & 858 & 849 & 833 \\
\hline Foreign affairs & 1,019 & 991 & 959 & 1,064 & 1,038 & 1,027 & 1,008 \\
\hline Public works & 539 & 524 & 507 & 562 & 548 & 543 & 533 \\
\hline Defense and security & 14,905 & 14,494 & 14,021 & 15,560 & 15,169 & 15,013 & 14,731 \\
\hline Other & 5,326 & 5,179 & 5,010 & 5,560 & 5,420 & 5,365 & 5,264 \\
\hline Total & 67,144 & 65,293 & 63,162 & 70,093 & 68,331 & 67,632 & 66,358 \\
\hline
\end{tabular}

Source: Congolese authorities. 
Table 18. Republic of Congo: Central Government Financial Operations, 1997-2003

\begin{tabular}{|c|c|c|c|c|c|c|c|}
\hline & 1997 & 1998 & 1999 & 2000 & 2001 & $\begin{array}{r}2002 \\
\text { Est. }\end{array}$ & $\begin{array}{l}2003 \\
\text { Prel. }\end{array}$ \\
\hline & \multicolumn{7}{|c|}{ (In billions of CFA francs) } \\
\hline Revenue and grants & 387.7 & 263.0 & 390.6 & 609.4 & 631.8 & 575.4 & 613.5 \\
\hline Revenue & 386.3 & 259.4 & 384.3 & 602.6 & 628.1 & 571.7 & 603.6 \\
\hline Oil revenue & 296.9 & 137.8 & 275.6 & 466.2 & 430.8 & 397.5 & 421.6 \\
\hline Non-oil revenue & 89.3 & 121.7 & 108.7 & 136.4 & 197.3 & 174.2 & 182.0 \\
\hline Domestic taxes & 43.1 & 78.0 & 76.4 & 92.6 & 126.9 & 125.3 & 134.0 \\
\hline Customs receipts & 35.0 & 34.8 & 21.7 & 31.2 & 43.3 & 36.1 & 43.3 \\
\hline Domestic petroleum taxes & 9.5 & 8.4 & 7.8 & 10.7 & 15.6 & 10.0 & 0.0 \\
\hline Nontax revenue & 1.8 & 0.4 & 2.8 & 1.9 & 11.5 & 2.8 & 4.7 \\
\hline Grants & 1.4 & 3.6 & 6.3 & 6.8 & 3.7 & 3.7 & 9.9 \\
\hline Expenditure and net lending & 508.6 & 492.8 & 475.4 & 583.5 & 645.9 & 746.4 & 606.1 \\
\hline Current expenditure & 462.0 & 438.2 & 386.3 & 424.1 & 440.6 & 563.1 & 470.5 \\
\hline Wage bill & 104.2 & 102.4 & 100.7 & 106.7 & 118.1 & 120.4 & 120.2 \\
\hline Other current expenditure & 177.8 & 175.0 & 111.0 & 156.1 & 159.8 & 256.7 & 223.6 \\
\hline Materials and supplies & 125.3 & 107.3 & 51.1 & 36.7 & 32.1 & 78.4 & 50.0 \\
\hline Common charges & 27.0 & 35.4 & 33.6 & 72.4 & 55.0 & 73.4 & 42.8 \\
\hline Transfers & 25.5 & 32.2 & 26.4 & 47.0 & 72.7 & 104.9 & 130.8 \\
\hline Local authorities & 2.0 & 0.9 & 6.5 & 2.4 & 10.7 & 9.3 & 8.9 \\
\hline Interest & 178.0 & 159.9 & 168.1 & 158.9 & 152.0 & 176.7 & 117.8 \\
\hline Domestic & 14.6 & 11.5 & 17.3 & 9.7 & 7.7 & 14.4 & 23.4 \\
\hline External & 163.5 & 148.4 & 150.8 & 149.2 & 144.3 & 162.3 & 94.4 \\
\hline Capital expenditure & 46.6 & 54.6 & 89.1 & 159.4 & 205.4 & 181.7 & 134.8 \\
\hline Domestically financed & 42.0 & 50.5 & 81.9 & 144.6 & 200.4 & 158.1 & 111.0 \\
\hline Externally financed & 4.6 & 4.1 & 7.2 & 14.8 & 5.0 & 23.6 & 23.8 \\
\hline Net lending & 0.0 & 0.0 & 0.0 & 0.0 & 0.0 & 1.6 & 0.8 \\
\hline Primary balance & 55.7 & -73.4 & 77.0 & 192.8 & 139.2 & 25.7 & 139.1 \\
\hline \multicolumn{8}{|l|}{ Balance, commitment basis } \\
\hline Excluding grants & -122.4 & -233.4 & -91.1 & 19.1 & -17.8 & -174.6 & -2.5 \\
\hline Including grants & -121.0 & -229.8 & -84.8 & 25.9 & -14.1 & -171.0 & 7.4 \\
\hline Change in arrears & -59.9 & 354.2 & 294.6 & 268.2 & 73.6 & 205.9 & 124.8 \\
\hline External & 37.6 & 338.3 & 262.5 & 283.4 & 104.5 & 210.8 & 164.2 \\
\hline Domestic & -97.5 & 15.9 & 32.1 & -15.2 & -30.9 & -5.0 & -39.5 \\
\hline Balance, cash basis & -180.9 & 124.4 & 209.8 & 294.1 & 59.5 & 34.9 & 132.2 \\
\hline
\end{tabular}


Table 18. Republic of Congo: Central Government Financial Operations, 1997-2003 (concluded)

\begin{tabular}{|c|c|c|c|c|c|c|c|}
\hline & 1997 & 1998 & 1999 & 2000 & 2001 & $\begin{array}{r}2002 \\
\text { Est. }\end{array}$ & $\begin{array}{l}2003 \\
\text { Prel. }\end{array}$ \\
\hline & \multicolumn{7}{|c|}{ (In billions of CFA francs) } \\
\hline Financing & 180.9 & -124.4 & -209.8 & -294.0 & -59.5 & -34.9 & -132.1 \\
\hline Foreign (net) & 149.7 & -152.7 & -177.1 & -239.4 & -85.0 & -15.0 & -146.1 \\
\hline Drawings & 15.6 & 2.3 & 4.3 & 44.0 & 73.4 & 234.1 & 21.6 \\
\hline Project financing & 3.2 & 0.5 & 0.9 & 8.0 & 1.3 & 20.0 & 13.9 \\
\hline Nonproject financing & 12.4 & 2.3 & 3.4 & 36.0 & 28.0 & 0.0 & 7.7 \\
\hline Other & 0.0 & 0.0 & 0.0 & 0.0 & 44.1 & 214.1 & 0.0 \\
\hline Amortization due & -245.1 & -268.2 & -258.8 & -292.7 & -233.6 & -259.7 & -169.3 \\
\hline Rescheduling obtained & 175.8 & 85.7 & 68.8 & 2.8 & 11.6 & 4.3 & 1.5 \\
\hline Debt cancellation & 203.3 & 27.7 & 8.6 & 6.5 & 63.6 & 6.4 & 0.1 \\
\hline Domestic (net) & 31.2 & 28.3 & -32.7 & -54.6 & 25.5 & -19.9 & 14.0 \\
\hline Banking system (net) & 31.7 & 12.4 & -21.9 & -13.9 & 75.1 & 23.2 & 1.0 \\
\hline Nonbank financing & -0.5 & 15.9 & -10.8 & -40.7 & -49.5 & -43.1 & 13.0 \\
\hline Sale of assets & 0.0 & 0.0 & 0.0 & 3.1 & 3.0 & 7.5 & 2.1 \\
\hline Cost of financial sector reforms & 0.0 & 0.0 & -2.3 & -18.7 & -20.9 & -3.8 & -0.6 \\
\hline Bond issues & 0.0 & 0.0 & 0.0 & 0.0 & 0.0 & 0.0 & 0.0 \\
\hline Cost of structural reforms & -0.5 & 0.0 & -8.7 & -9.2 & -1.2 & -7.6 & -7.6 \\
\hline \multirow[t]{2}{*}{ Exceptional oil receipts } & 0.0 & 18.4 & 3.9 & 0.0 & 0.0 & 0.0 & 59.2 \\
\hline & 0.0 & -2.5 & -3.7 & -15.9 & -9.3 & -16.9 & -40.1 \\
\hline Financing gap & 0.0 & 0.0 & 0.0 & 0.0 & 0.0 & 0.0 & 0.0 \\
\hline & \multicolumn{7}{|c|}{ (In percent of GDP) } \\
\hline Revenue and grants & 28.6 & 22.9 & 27.0 & 26.6 & 30.9 & 27.4 & 30.1 \\
\hline Of which: revenue & 28.5 & 22.6 & 26.5 & 26.3 & 30.7 & 27.2 & 29.6 \\
\hline Expenditure & 37.5 & 42.9 & 32.8 & 25.5 & 31.6 & 35.5 & 29.7 \\
\hline Current & 34.1 & 38.1 & 26.7 & 18.5 & 21.6 & 26.8 & 23.1 \\
\hline Capital & 12.1 & 12.9 & 10.4 & 6.5 & 7.1 & 7.7 & 4.6 \\
\hline \multicolumn{8}{|l|}{ Balance, commitment basis } \\
\hline Including grants & -8.9 & -20.0 & -5.9 & 1.1 & -0.7 & -8.1 & 0.4 \\
\hline Excluding grants & -9.0 & -20.3 & -6.3 & 0.8 & -0.9 & -8.3 & -0.1 \\
\hline Primary balance & 4.1 & -6.4 & 5.3 & 8.4 & 6.8 & 1.2 & 6.8 \\
\hline Memorandum items: & \multicolumn{7}{|c|}{ (In billions of CFA francs, unless otherwise indicated) } \\
\hline GDP at current market prices & $1,355.7$ & $1,150.1$ & $1,449.3$ & $2,292.5$ & $2,043.4$ & $2,103.0$ & $2,040.0$ \\
\hline Non-oil GDP at current market prices & 689.0 & 730.5 & 676.0 & 790.2 & 884.8 & 976.6 & $1,036.6$ \\
\hline Oil production (millions of barrels) & 85.7 & 91.0 & 94.8 & 96.8 & 89.6 & 88.0 & 81.7 \\
\hline
\end{tabular}

Sources: Ministry of Economy, Finance, and the Budget; and staff estimates. 
Table 19. Republic of Congo: Central Government Revenue, 1997-2003

(In billions of CFA francs)

\begin{tabular}{|c|c|c|c|c|c|c|c|}
\hline & 1997 & 1998 & 1999 & 2000 & 2001 & $\begin{array}{c}2002 \\
\text { Est. }\end{array}$ & $\begin{array}{l}2003 \\
\text { Prel. }\end{array}$ \\
\hline Revenue and grants & 387.7 & 263.0 & 390.6 & 609.4 & 631.8 & 575.4 & 613.5 \\
\hline Revenue & 386.3 & 259.4 & 384.3 & 602.6 & 628.1 & 571.7 & 603.6 \\
\hline Oil receipts & 296.9 & 137.8 & 275.6 & 468.1 & 430.8 & 397.5 & 421.6 \\
\hline Royalties & 109.0 & 76.6 & 101.6 & 468.1 & 430.8 & 395.7 & 381.1 \\
\hline Profit sharing & 146.8 & 66.9 & 65.7 & 0.0 & 0.0 & 0.0 & 0.0 \\
\hline Of which: government share sold by SNPC 1/ & 12.8 & 10.8 & 99.6 & 119.3 & 37.2 & 120.4 & 251.1 \\
\hline Earmarked investment funds & 5.1 & 3.3 & 4.5 & 1.9 & 0.7 & 3.7 & 6.2 \\
\hline Other (net) & 23.2 & -19.8 & 4.1 & 164.8 & 270.5 & 193.6 & 0.0 \\
\hline Non-oil revenue & 89.3 & 121.7 & 108.7 & 136.4 & 197.3 & 174.2 & 182.0 \\
\hline Taxes & 43.1 & 78.0 & 76.4 & 92.6 & 126.9 & 125.3 & 134.0 \\
\hline Direct taxes & 33.8 & 39.0 & 42.0 & 48.2 & 59.1 & 57.3 & 64.3 \\
\hline Indirect taxes & 9.3 & 39.0 & 34.4 & 44.4 & 67.8 & 68.0 & 69.7 \\
\hline Customs receipts & 35.0 & 34.8 & 21.7 & 31.2 & 43.3 & 36.1 & 43.3 \\
\hline Domestic petroleum taxes & 9.5 & 8.4 & 7.8 & 10.7 & 15.6 & 10.0 & 0.0 \\
\hline Nontax revenue & 1.8 & 0.4 & 2.8 & 1.9 & 11.5 & 2.8 & 4.7 \\
\hline Grants & 1.4 & 3.6 & 6.3 & 6.8 & 3.7 & 3.7 & 9.9 \\
\hline
\end{tabular}

Sources: Ministry of Economy, Finance, and the Budget; and staff estimates.

1/ SNPC = Société Nationale des Pétroles du Congo (national oil company). 
Table 20. Republic of Congo: Central Government Revenue Trends, 1997-2003

\begin{tabular}{|c|c|c|c|c|c|c|c|}
\hline & 1997 & 1998 & 1999 & 2000 & 2001 & $\begin{array}{r}2002 \\
\text { Est. }\end{array}$ & $\begin{array}{l}2003 \\
\text { Prel. }\end{array}$ \\
\hline & \multicolumn{7}{|c|}{ (In percent of GDP) } \\
\hline Revenue and grants & 28.6 & 22.9 & 27.0 & 26.6 & 30.9 & 27.4 & 30.1 \\
\hline Revenue & 28.5 & 22.6 & 26.5 & 26.3 & 30.7 & 27.2 & 29.6 \\
\hline Fiscal oil receipts & 21.9 & 12.0 & 19.0 & 20.4 & 21.1 & 18.9 & 20.7 \\
\hline Royalties & 8.0 & 6.7 & 7.0 & 20.4 & 21.1 & 18.8 & 18.7 \\
\hline Profit sharing & 10.8 & 5.8 & 4.5 & 0.0 & 0.0 & 0.0 & 0.0 \\
\hline Of which: government share sold by SNPC 1/ & 0.9 & 0.9 & 6.9 & 5.2 & 1.8 & 5.7 & 12.3 \\
\hline Earmarked investment funds & 0.4 & 0.3 & 0.3 & 0.1 & 0.0 & 0.2 & 0.3 \\
\hline Other (net) & 1.7 & -1.7 & 0.3 & 7.2 & 13.2 & 9.2 & 0.0 \\
\hline Non-oil revenue & 6.6 & 10.6 & 7.5 & 5.9 & 9.7 & 8.3 & 8.9 \\
\hline Taxes & 3.2 & 6.8 & 5.3 & 4.0 & 6.2 & 6.0 & 6.6 \\
\hline Direct taxes & 2.5 & 3.4 & 2.9 & 2.1 & 2.9 & 2.7 & 3.2 \\
\hline Indirect taxes & 0.7 & 3.4 & 2.4 & 1.9 & 3.3 & 3.2 & 3.4 \\
\hline Customs receipts & 2.6 & 3.0 & 1.5 & 1.4 & 2.1 & 1.7 & 2.1 \\
\hline Domestic petroleum taxes & 0.7 & 0.7 & 0.5 & 0.5 & 0.8 & 0.5 & 0.0 \\
\hline Nontax revenue & 0.1 & 0.0 & 0.2 & 0.1 & 0.6 & 0.1 & 0.2 \\
\hline \multirow[t]{2}{*}{ Grants } & 0.1 & 0.3 & 0.4 & 0.3 & 0.2 & 0.2 & 0.5 \\
\hline & \multicolumn{7}{|c|}{ (In percent of non-oil GDP) } \\
\hline Non-oil revenue & 13.0 & 16.7 & 16.1 & 17.3 & 22.3 & 17.8 & 17.6 \\
\hline Taxes & 6.2 & 10.7 & 11.3 & 11.7 & 14.3 & 12.8 & 12.9 \\
\hline Direct taxes & 4.9 & 5.3 & 6.2 & 6.1 & 6.7 & 5.9 & 6.2 \\
\hline Indirect taxes & 1.3 & 5.3 & 5.1 & 5.6 & 7.7 & 7.0 & 6.7 \\
\hline Customs receipts & 5.1 & 4.8 & 3.2 & 3.9 & 4.9 & 3.7 & 4.2 \\
\hline Domestic petroleum taxes & 1.4 & 1.1 & 1.2 & 1.4 & 1.8 & 1.0 & 0.0 \\
\hline \multirow[t]{2}{*}{ Nontax revenue } & 0.3 & 0.1 & 0.4 & 0.2 & 1.3 & 0.3 & 0.5 \\
\hline & \multicolumn{7}{|c|}{ (In percent of oil GDP) } \\
\hline Oil revenue & 44.5 & 32.8 & 35.6 & 31.0 & 37.2 & 35.3 & 42.0 \\
\hline Royalties & 16.3 & 18.3 & 13.1 & 31.2 & 37.2 & 35.1 & 38.0 \\
\hline Other & 28.2 & 14.6 & 22.5 & -0.1 & 0.0 & 0.2 & 4.0 \\
\hline
\end{tabular}


Table 20. Republic of Congo: Central Government Revenue Trends, 1997-2003 (concluded)

\begin{tabular}{|c|c|c|c|c|c|c|c|}
\hline & 1997 & 1998 & 1999 & 2000 & 2001 & $\begin{array}{r}2002 \\
\text { Est. }\end{array}$ & $\begin{array}{c}2003 \\
\text { Prel. }\end{array}$ \\
\hline & \multicolumn{7}{|c|}{ (Annual percentage change) } \\
\hline Revenue and grants & 7.1 & -32.1 & 48.5 & 56.0 & 3.7 & -8.9 & 6.6 \\
\hline Revenue & 8.0 & -32.8 & 48.1 & 56.8 & 4.2 & -9.0 & 5.6 \\
\hline Fiscal oil receipts & 39.3 & -53.6 & 100.0 & 69.1 & -7.6 & -7.7 & 6.1 \\
\hline Non-oil revenue & -38.2 & 36.2 & -10.7 & 25.5 & 44.7 & -11.7 & 4.4 \\
\hline Taxes & -38.1 & 81.2 & -2.1 & 21.2 & 37.0 & -1.2 & 6.9 \\
\hline Customs receipts & -40.0 & -0.4 & -37.7 & 43.8 & 38.7 & -16.6 & 19.9 \\
\hline Domestic petroleum taxes & -31.2 & -11.8 & -6.8 & 37.2 & 45.8 & -35.9 & -100.0 \\
\hline \multirow[t]{2}{*}{ Nontax revenue } & -40.0 & -75.1 & 523.6 & -32.1 & 507.2 & -75.7 & 67.9 \\
\hline & \multicolumn{7}{|c|}{ (In percent of total revenue, excluding grants) } \\
\hline Fiscal oil receipts & 76.9 & 53.1 & 71.7 & 77.4 & 68.6 & 69.5 & 69.8 \\
\hline Non-oil revenue & 23.1 & 46.9 & 28.3 & 22.6 & 31.4 & 30.5 & 30.2 \\
\hline Taxes & 11.1 & 30.1 & 19.9 & 15.4 & 20.2 & 21.9 & 22.2 \\
\hline Customs receipts & 9.1 & 13.4 & 5.6 & 5.2 & 6.9 & 6.3 & 7.2 \\
\hline Domestic petroleum taxes & 2.5 & 3.2 & 2.0 & 1.8 & 2.5 & 1.7 & 0.0 \\
\hline Nontax revenue & 0.5 & 0.2 & 0.7 & 0.3 & 1.8 & 0.5 & 0.8 \\
\hline
\end{tabular}

Sources: Ministry of Economy, Finance, and the Budget; and staff estimates.

1/ SNPC $=$ Société Nationale des Pétroles du Congo (national oil company). 
Table 21. Republic of Congo: Central Government Expenditure Trends, 1997-2003

\begin{tabular}{|c|c|c|c|c|c|c|c|}
\hline & 1997 & 1998 & 1999 & 2000 & 2001 & $\begin{array}{r}2002 \\
\text { Est. }\end{array}$ & $\begin{array}{l}2003 \\
\text { Prel. }\end{array}$ \\
\hline & \multicolumn{7}{|c|}{ (In percent of GDP) } \\
\hline Total current expenditure & 37.5 & 42.9 & 32.8 & 25.5 & 31.6 & 35.4 & 29.7 \\
\hline Noninterest current expenditure & 20.9 & 24.2 & 15.1 & 11.6 & 14.1 & 18.4 & 17.3 \\
\hline Wages and salaries & 7.7 & 8.9 & 6.9 & 4.7 & 5.8 & 5.7 & 5.9 \\
\hline Goods and services & 9.2 & 9.3 & 3.5 & 1.6 & 1.6 & 3.7 & 2.5 \\
\hline Common charges & 2.0 & 3.1 & 2.3 & 3.2 & 2.7 & 3.5 & 2.1 \\
\hline Transfers and subsidies & 1.9 & 2.8 & 1.8 & 2.1 & 3.6 & 5.0 & 6.4 \\
\hline Local authorities & 0.1 & 0.1 & 0.4 & 0.1 & 0.5 & 0.4 & 0.4 \\
\hline \multirow[t]{2}{*}{ Interest due } & 13.1 & 13.9 & 11.6 & 6.9 & 7.4 & 8.4 & 5.8 \\
\hline & \multicolumn{7}{|c|}{ (In percent of non-oil GDP) } \\
\hline Total current expenditure & 67.1 & 60.0 & 57.1 & 53.7 & 49.8 & 57.7 & 45.4 \\
\hline Noninterest current expenditure & 41.2 & 38.1 & 32.3 & 33.6 & 32.6 & 39.6 & 34.0 \\
\hline Wages and salaries & 15.1 & 14.0 & 14.9 & 13.5 & 13.3 & 12.3 & 11.6 \\
\hline Goods and services & 18.2 & 14.7 & 7.6 & 4.6 & 3.6 & 8.0 & 4.8 \\
\hline Common charges & 3.9 & 4.9 & 5.0 & 9.2 & 6.2 & 7.5 & 4.1 \\
\hline Transfers and subsidies & 3.7 & 4.4 & 3.9 & 5.9 & 8.2 & 10.7 & 12.6 \\
\hline Local authorities & 0.3 & 0.1 & 1.0 & 0.3 & 1.2 & 1.0 & 0.9 \\
\hline \multirow[t]{2}{*}{ Interest due } & 25.8 & 21.9 & 24.9 & 20.1 & 17.2 & 18.1 & 11.4 \\
\hline & \multicolumn{7}{|c|}{ (In percent of total current expenditure) } \\
\hline Wages and salaries & 22.6 & 23.4 & 26.1 & 25.2 & 26.8 & 21.4 & 25.5 \\
\hline Other current expenditure & 38.5 & 39.9 & 28.7 & 36.8 & 36.3 & 45.6 & 47.5 \\
\hline \multirow[t]{2}{*}{ Interest due } & 38.5 & 36.5 & 43.5 & 37.5 & 34.5 & 31.4 & 25.0 \\
\hline & \multicolumn{7}{|c|}{ (Annual percentage change) } \\
\hline Total current expenditure & 39.4 & -5.1 & -11.8 & 9.8 & 3.9 & 27.8 & -16.4 \\
\hline Other current expenditure & 209.7 & -1.6 & -36.6 & 40.6 & 2.4 & 60.6 & -12.9 \\
\hline Interest due & 8.3 & -10.1 & 5.1 & -5.5 & -4.4 & 16.3 & -33.3 \\
\hline
\end{tabular}

Sources: Ministry of Economy, Finance, and the Budget; and staff estimates. 
Table 22. Republic of Congo: Monetary Survey, 1997-2003

\begin{tabular}{|c|c|c|c|c|c|c|c|}
\hline & 1997 & 1998 & 1999 & 2000 & 2001 & $\begin{array}{r}2002 \\
\text { Est. }\end{array}$ & $\begin{array}{c}2003 \\
\text { Prel. }\end{array}$ \\
\hline & \multicolumn{7}{|c|}{ (In billions of CFA francs; end of period) } \\
\hline Net foreign assets & 26.2 & -35.6 & 5.0 & 151.8 & 26.9 & 38.0 & 6.0 \\
\hline Central bank & 18.0 & -28.4 & 8.3 & 128.4 & 23.9 & -0.9 & 4.6 \\
\hline Deposit money banks & 8.2 & -7.2 & -3.3 & 23.4 & 3.0 & 38.9 & 1.4 \\
\hline Net domestic assets & 175.5 & 211.5 & 205.9 & 182.5 & 231.1 & 253.7 & 278.6 \\
\hline Net domestic credit & 237.5 & 252.7 & 276.0 & 257.1 & 267.2 & 249.7 & 265.5 \\
\hline Net credit to the public sector & 116.2 & 123.1 & 102.6 & 93.2 & 158.2 & 183.3 & 183.8 \\
\hline Net credit to the government & 116.6 & 129.0 & 107.0 & 93.2 & 163.5 & 186.8 & 187.9 \\
\hline Central bank & 101.4 & 111.8 & 108.0 & 107.7 & 160.3 & 173.9 & 182.0 \\
\hline Claims & 121.0 & 123.1 & 120.8 & 128.7 & 173.2 & 181.6 & 195.3 \\
\hline Statutory advances & 66.9 & 82.3 & 81.8 & 81.7 & 123.1 & 137.3 & 161.0 \\
\hline Use of IMF credit & 20.1 & 19.1 & 18.9 & 29.1 & 28.8 & 20.8 & 14.6 \\
\hline Consolidated credit & 34.0 & 21.7 & 20.0 & 17.9 & 21.3 & 23.6 & 19.7 \\
\hline Deposits & 19.6 & 11.3 & 12.8 & 21.0 & 12.9 & 7.7 & 13.1 \\
\hline Deposit money banks & 15.2 & 17.2 & -0.9 & -14.5 & 3.2 & 12.8 & 5.8 \\
\hline Claims on public agencies, net & -0.4 & -5.9 & -4.5 & 0.0 & -5.3 & -3.4 & -4.1 \\
\hline Credit to the economy 1 / & 121.3 & 129.6 & 173.4 & 163.9 & 109.0 & 66.4 & 81.7 \\
\hline Other items, net & -62.0 & -41.2 & -70.1 & -74.6 & -36.1 & 4.0 & 13.1 \\
\hline Broad money & 201.7 & 175.9 & 210.9 & 334.3 & 258.0 & 291.7 & 284.6 \\
\hline Currency outside banks & 93.3 & 73.3 & 102.3 & 123.9 & 142.9 & 129.0 & 131.9 \\
\hline Demand deposits & 73.3 & 70.7 & 81.7 & 185.7 & 95.2 & 142.2 & 103.3 \\
\hline \multirow[t]{2}{*}{ Time deposits } & 35.1 & 31.9 & 26.8 & 24.7 & 19.9 & 20.5 & 49.4 \\
\hline & \multicolumn{7}{|c|}{ (Changes in percent of beginning-of-period broad money) } \\
\hline Net foreign assets & -3.9 & -30.6 & 23.1 & 69.6 & -37.3 & 4.3 & -11.0 \\
\hline Net domestic assets & 13.5 & 17.9 & -3.2 & -11.1 & 14.5 & 8.8 & 8.5 \\
\hline Net domestic credit & 21.2 & 7.5 & 13.2 & -8.9 & 3.0 & -6.8 & 5.4 \\
\hline Net credit to the government & 17.2 & 6.1 & -12.5 & -6.6 & 21.0 & 9.0 & 0.4 \\
\hline Credit to the economy & 4.5 & 4.1 & 24.9 & -4.5 & -16.4 & -16.5 & 5.3 \\
\hline \multirow[t]{2}{*}{ Broad money } & 9.5 & -12.8 & 19.9 & 58.5 & -22.8 & 13.1 & -2.4 \\
\hline & \multicolumn{7}{|c|}{ (Annual percent changes, unless otherwise indicated) } \\
\hline Credit to the economy & 7.3 & 6.8 & 33.8 & -5.4 & -33.5 & -39.1 & 23.1 \\
\hline Broad money & 9.5 & -12.8 & 19.9 & 58.5 & -22.8 & 13.1 & -2.4 \\
\hline Currency outside banks & 6.8 & -21.5 & 39.7 & 21.0 & 15.4 & -9.7 & 2.3 \\
\hline \multicolumn{8}{|l|}{ Memorandum items: } \\
\hline \multicolumn{8}{|l|}{ Velocity } \\
\hline Total GDP/average M2 & 3.6 & 3.9 & 3.5 & 2.9 & 3.0 & 3.6 & 3.6 \\
\hline Non-oil GDP/average M2 & 7.0 & 6.1 & 7.5 & 8.4 & 6.9 & 7.7 & 7.1 \\
\hline Non-oil GDP/end-period M2 & 3.4 & 4.2 & 3.2 & 2.4 & 3.4 & 3.3 & 3.6 \\
\hline Total GDP growth & 4.3 & -15.2 & 26.0 & 58.2 & -10.9 & 2.9 & -3.0 \\
\hline Non-oil GDP growth & -8.0 & 6.0 & -7.5 & 16.9 & 12.0 & 10.4 & 6.1 \\
\hline Credit to the economy/non-oil GDP (in percent) & 17.6 & 17.7 & 25.6 & 20.7 & 12.3 & 6.8 & 7.9 \\
\hline
\end{tabular}

Sources: Bank of Central African States (BEAC); and staff estimates.

1/ Including public enterprises. 
Table 23. Republic of Congo: Summary Accounts of the Central Bank, 1997-2003

\begin{tabular}{|c|c|c|c|c|c|c|c|}
\hline & 1997 & 1998 & 1999 & 2000 & 2001 & $\begin{array}{r}2002 \\
\text { Est. }\end{array}$ & $\begin{array}{c}2003 \\
\text { Prel. }\end{array}$ \\
\hline & \multicolumn{7}{|c|}{ (In billions of CFA francs; end of period) } \\
\hline Net foreign assets & 18.0 & -28.4 & 8.3 & 128.4 & 23.9 & -0.9 & 4.6 \\
\hline Assets & 37.8 & 2.3 & 27.8 & 158.6 & 53.6 & 22.2 & 21.4 \\
\hline Liabilities & -19.8 & -30.7 & -19.5 & -30.3 & -29.7 & -23.0 & -16.8 \\
\hline Net domestic assets & 90.3 & 115.5 & 106.8 & 101.5 & 149.1 & 159.2 & 157.4 \\
\hline Net credit to the government & 101.4 & 111.8 & 108.0 & 107.7 & 160.3 & 173.9 & 182.0 \\
\hline Claims & 121.0 & 123.1 & 120.8 & 128.7 & 173.2 & 181.6 & 195.3 \\
\hline \multicolumn{8}{|l|}{ Of which } \\
\hline Statutory advances & 66.9 & 82.3 & 81.8 & 81.7 & 123.1 & 137.3 & 161.0 \\
\hline Use of IMF credit & 20.1 & 19.1 & 18.9 & 29.1 & 28.8 & 20.8 & 14.6 \\
\hline Deposits & 19.6 & 11.3 & 12.8 & 21.0 & 12.9 & 7.7 & 13.1 \\
\hline Claims on deposit money banks & 5.0 & 7.2 & 6.2 & 6.5 & 2.4 & 0.0 & 0.0 \\
\hline Claims on nonbank institutions & 0.0 & 0.0 & 0.0 & 0.0 & 0.0 & 0.0 & 0.0 \\
\hline Other items, net & -16.0 & -3.5 & -7.4 & -12.6 & -13.6 & -14.7 & -24.6 \\
\hline Reserve money at BEAC & 108.3 & 87.1 & 115.1 & 229.9 & 173.0 & 158.3 & 162.0 \\
\hline Currency outside banks & 93.3 & 73.3 & 102.3 & 123.9 & 142.9 & 129.0 & 131.9 \\
\hline Banks' reserves & 15.1 & 13.9 & 12.7 & 106.0 & 30.1 & 29.3 & 30.1 \\
\hline Deposits at BEAC & 9.0 & 2.9 & 1.7 & 93.1 & 19.7 & 18.2 & 19.2 \\
\hline Currency in vault & 6.1 & 10.9 & 11.0 & 12.9 & 10.4 & 11.2 & 10.9 \\
\hline Memorandum items: & \multicolumn{7}{|c|}{ (In percent, unless otherwise indicated) } \\
\hline Reserve money/deposits & 99.9 & 84.9 & 106.0 & 109.2 & 150.3 & 97.3 & 106.1 \\
\hline Reserve money/broad money & 53.7 & 49.5 & 54.6 & 68.8 & 67.0 & 54.3 & 56.9 \\
\hline Reserve money multiplier (level) & 1.9 & 2.0 & 1.8 & 1.5 & 1.5 & 1.8 & 1.8 \\
\hline Reserve money annual growth & 12.5 & -19.6 & 32.1 & 99.8 & -24.7 & -8.5 & 2.3 \\
\hline
\end{tabular}

Sources: Bank of Central African States (BEAC); and staff estimates. 
Table 24. Republic of Congo: Summary Accounts of the Commercial Banks, 1997-2003

(In billions of CFA francs; end of period)

\begin{tabular}{|c|c|c|c|c|c|c|c|}
\hline & 1997 & 1998 & 1999 & 2000 & 2001 & $\begin{array}{r}2002 \\
\text { Est. }\end{array}$ & $\begin{array}{c}2003 \\
\text { Prel. }\end{array}$ \\
\hline Net foreign assets & 8.2 & -7.2 & -3.3 & 23.4 & 3.0 & 38.9 & 1.4 \\
\hline Assets & 16.6 & 16.3 & 22.2 & 36.1 & 16.3 & 81.8 & 22.1 \\
\hline Liabilities & -8.5 & -23.5 & -25.6 & -12.7 & -13.2 & -43.0 & -20.7 \\
\hline Net domestic assets & 100.3 & 109.9 & 111.9 & 187.0 & 112.1 & 123.8 & 151.4 \\
\hline Net credit to the public sector & 14.8 & 11.3 & -5.4 & -14.5 & 3.2 & 30.4 & 15.4 \\
\hline Net credit to the government & 15.2 & 17.2 & -1.0 & -14.5 & 8.5 & 33.9 & 15.4 \\
\hline Claims & 23.9 & 26.9 & -1.5 & -22.8 & 14.5 & 57.5 & 26.1 \\
\hline Deposits & -8.7 & -9.8 & 0.5 & 8.3 & -6.0 & -23.6 & -10.7 \\
\hline Net credit to public agencies & -0.4 & -5.9 & -4.5 & 0.0 & -5.3 & -3.4 & 0.0 \\
\hline Claims & 3.6 & 3.5 & 1.6 & 6.2 & 0.6 & 1.2 & 0.0 \\
\hline Deposits & -4.1 & -9.3 & -6.0 & -6.2 & -5.9 & -4.6 & 0.0 \\
\hline Credit to private sector $1 /$ & 121.3 & 129.6 & 173.4 & 163.9 & 109.0 & 66.4 & 81.7 \\
\hline Net position with central bank & 20.1 & 21.0 & 18.9 & 112.4 & 32.5 & 29.3 & 30.1 \\
\hline Borrowing & 5.0 & 7.2 & 6.2 & 6.5 & 2.4 & 0.0 & 0.0 \\
\hline Reserves & 15.1 & 13.9 & 12.7 & 106.0 & 30.1 & 29.3 & 30.1 \\
\hline Deposits & 9.0 & 2.9 & 1.7 & 93.1 & 19.7 & 18.2 & 19.2 \\
\hline Currency in vault & 6.1 & 10.9 & 11.0 & 12.9 & 10.4 & 11.2 & 10.9 \\
\hline Other items, net & -56.0 & -52.1 & -75.0 & -74.9 & -32.6 & -2.4 & 24.1 \\
\hline Liabilities to the private sector & 108.4 & 102.7 & 108.5 & 210.4 & 115.1 & 162.7 & 152.8 \\
\hline Demand deposits & 73.3 & 70.7 & 81.7 & 185.7 & 95.2 & 142.2 & 103.3 \\
\hline Time deposits & 35.1 & 31.9 & 26.8 & 24.7 & 19.9 & 20.5 & 49.4 \\
\hline
\end{tabular}

Sources: Bank of Central African States (BEAC); and staff estimates.

1/ Including public enterprises. 
Table 25. Republic of Congo: Interest Rate Structure, 1997-2003

(In percent per annum; end of period or date of change)

\begin{tabular}{lrrrrrrr}
\hline & 1997 & 1998 & 1999 & 2000 & 2001 & $\begin{array}{r}2002 \\
\text { Est. }\end{array}$ & $\begin{array}{r}2003 \\
\text { Prel. }\end{array}$ \\
& & & & & & & \\
& & & & & & & \\
Central bank rates 1/ & & & & & & & \\
National treasury & & & & & & & \\
$\quad$ Lending operations & 7.50 & 7.00 & 7.60 & 7.00 & 6.50 & 6.30 & 6.00 \\
$\quad$ Advances 2/ & 10.25 & 10.50 & 10.50 & 10.50 & 10.50 & 10.50 & 10.00 \\
$\quad$ Penalty 3/ & & & & & & & \\
Borrowing operations & 3.00 & 2.75 & 3.15 & 3.60 & 3.60 & 2.70 & 1.95 \\
$\quad$ Special deposit (TDRS) & & & & & & & \\
Banking institutions & & & & & & & \\
Lending operations & 9.50 & 9.00 & 9.60 & 9.00 & 8.50 & 8.30 & 7.80 \\
$\quad$ Prise en pension (TIPP) 4/ & 7.50 & 7.00 & 7.60 & 7.00 & 6.50 & 6.30 & 6.00 \\
$\quad$ Money market (TIAO) 5/6/ & 15.00 & 15.00 & 15.00 & 15.00 & 15.00 & 15.00 & 15.00 \\
$\quad$ Penalty (TPB) 7/ & $\ldots$ & $\ldots$ & $\ldots$ & $\ldots$ & 1.20 & 0.8 & $\ldots$ \\
Required reserves & & & & & & & \\
Borrowing operations & 3.00 & 2.75 & 3.15 & 3.60 & 3.60 & 2.70 & 1.95 \\
$\quad$ Special deposit (TDRS) 8/ & $9.50-15$ & $9.00-15$ & $9.60-15$ & $9.00-15$ & $8.50-15$ & $8.30-15$ & $7.80-15$ \\
$\quad$ Money market (TISP) 5/ 9/ & 3.00 & 2.75 & 3.15 & 3.60 & 3.60 & 2.70 & 1.95 \\
$\quad$ Certificates 7 days & 3.06 & 2.81 & 3.21 & 3.66 & 3.66 & 2.76 & 2.01 \\
$\quad$ Certificates 28 days & 3.13 & 2.88 & 3.28 & 3.73 & 3.73 & 2.83 & 2.08 \\
$\quad$ Certificates 84 days & & & & & & & \\
Commercial bank rates & 22.00 & 22.00 & 22.00 & 22.00 & 18.00 & 18.00 & 18.00 \\
Maximum lending rate (TDM) 10/ & 5.00 & 4.75 & 5.00 & 5.00 & 5.00 & 5.00 & 5.00 \\
Minimum deposit rate (TCM) 11/ & & & & & &
\end{tabular}

Source: Bank of Central African States (BEAC).

1/ Since February 5, 1996, the BEAC has used certificates of investment (certificat de placement - appels d'offres négatifs) auctioned to eligible financial institutions at rates and in amounts determined by the Governor of the BEAC; it has also extended access to the money market to selected nonbank financial institutions, monitored the publication of prime lending rates by lending rates at commercial banks (taux de base bancaire), set maximum penalty rates plus 700 points, and limited the application of minimum deposit rates to passbook saving deposits of less than CFAF 5 million.

2/ Rates apply to advances to national treasuries in the BEAC zone within the central bank's statutory ceilings.

3/ Rates apply to advances to national treasuries in the BEAC zone above the central bank's statutory ceilings.

4/ Rates apply to direct access to central bank credit subject to the provision of acceptable collateral. Rates are set at 100-300 basis points above the money market rates.

5 / The financial institutions admitted to the money market currently are the BIDC, UCB, BGFI, CAIC, and MUCODEC.

6/ The rates are administered by the BEAC and apply to lending operations through auctions in the money market (positive auctions).

7/ Penalty rates apply to nonreimbursed advances in the money market, or as a sanction on individual banking institutions.

8/ Rates apply to free reserves in addition to required reserves deposited with the central bank. Remuneration of free reserves was discontinued on February 5, 1996 after the introduction of certificates of investment.

9/ The rates are administered by the BEAC and apply to certificates of investment offered in the money market since February 5, 1996.

10/ TDM, taux débiteur maximum.

11/ TCM, taux créditeur minimum. Rates apply to small savings deposits only. 
Table 26. Republic of Congo: Balance of Payments, 1997-2003 1/

\begin{tabular}{|c|c|c|c|c|c|c|c|}
\hline & 1997 & 1998 & 1999 & 2000 & 2001 & $\begin{array}{r}2002 \\
\text { Est. }\end{array}$ & $\begin{array}{c}2003 \\
\text { Prel. }\end{array}$ \\
\hline & \multicolumn{7}{|c|}{ (In billions of CFA francs) } \\
\hline Current account & -175.3 & -237.0 & -248.4 & 182.0 & -64.6 & -6.9 & 7.6 \\
\hline Trade balance & 588.4 & 478.5 & 636.2 & $1,319.7$ & $1,007.1$ & $1,075.1$ & $1,003.8$ \\
\hline Exports, f.o.b. & 967.1 & 808.0 & 958.0 & $1,743.8$ & $1,506.6$ & $1,567.3$ & $1,475.6$ \\
\hline Oil sector & 769.6 & 708.2 & 879.6 & $1,633.2$ & $1,341.4$ & $1,373.8$ & $1,225.7$ \\
\hline Non-oil sector & 197.5 & 99.8 & 78.5 & 110.6 & 165.2 & 193.5 & 249.9 \\
\hline Imports, f.o.b. & -378.7 & -329.4 & -321.8 & -424.1 & -499.5 & -492.2 & -471.8 \\
\hline Oil sector & -65.4 & -108.4 & -48.6 & -70.3 & -179.3 & -70.1 & -70.1 \\
\hline Government & -153.7 & -83.1 & -69.9 & -91.9 & -123.2 & -108.4 & -81.2 \\
\hline Non-oil private sector & -159.6 & -137.9 & -203.4 & -262.0 & -197.0 & -313.7 & -320.4 \\
\hline Balance of services & -378.7 & -436.4 & -444.9 & -478.5 & -462.8 & -514.0 & -492.8 \\
\hline Oil sector & -302.0 & -391.5 & -388.5 & -381.9 & -358.8 & -352.4 & -352.3 \\
\hline Non-oil sector & -76.6 & -45.0 & -56.4 & -96.6 & -104.1 & -161.6 & -140.5 \\
\hline Balance of goods and services & 209.7 & 42.1 & 191.3 & 841.2 & 544.3 & 561.1 & 511.0 \\
\hline Income & -386.1 & -277.3 & -436.5 & -672.6 & -611.3 & -570.7 & -507.2 \\
\hline Labor income & -16.2 & -16.7 & -19.2 & -16.6 & -19.2 & -21.7 & -13.2 \\
\hline Investment income & -369.9 & -260.6 & -417.3 & -656.0 & -592.0 & -549.0 & -494.0 \\
\hline Of which: interest on public debt & -164.3 & -148.9 & -151.1 & -149.5 & -145.1 & -123.3 & -88.3 \\
\hline Current transfers (net) & 1.2 & -1.8 & -3.3 & 13.4 & 2.3 & 2.7 & 3.8 \\
\hline Private & -2.4 & -6.3 & -3.6 & 5.0 & -1.9 & -1.7 & -0.6 \\
\hline Public & 3.6 & 4.5 & 0.4 & 8.4 & 4.2 & 4.4 & 4.3 \\
\hline Capital account & 211.4 & 31.3 & 14.9 & 14.3 & 69.2 & 10.7 & 8.5 \\
\hline Official grants & 1.4 & 3.6 & 6.3 & 6.8 & 3.7 & 3.7 & 9.9 \\
\hline Debt cancellation & 203.3 & 27.7 & 8.6 & 6.5 & 63.6 & 6.4 & -2.6 \\
\hline Other & 6.7 & 0.0 & 0.0 & 1.0 & 1.9 & 0.7 & 1.2 \\
\hline Financial account & -34.3 & 253.7 & 256.7 & -35.1 & -107.2 & 20.8 & -5.5 \\
\hline Direct investment (net) & 44.2 & 24.1 & 319.5 & 340.2 & 160.0 & 156.6 & 187.4 \\
\hline Of which : oil sector & 39.9 & 43.3 & 306.9 & 286.9 & 152.1 & 147.8 & 150.9 \\
\hline Portfolio investment & -3.0 & -7.5 & -10.9 & 0.2 & -5.3 & -5.9 & -3.7 \\
\hline Other investment & -75.5 & 237.1 & -51.9 & -375.5 & -262.0 & -129.9 & -189.2 \\
\hline Medium and long term & -73.7 & 139.5 & -343.7 & -116.4 & -206.5 & 107.3 & -65.9 \\
\hline Public sector & -16.1 & 158.0 & 76.8 & 36.6 & -44.1 & 189.4 & 15.8 \\
\hline Drawings & 15.6 & 2.3 & 4.3 & 44.0 & 73.4 & 234.1 & 21.6 \\
\hline Project & 3.2 & 0.5 & 0.9 & 8.0 & 1.3 & 20.0 & 13.9 \\
\hline Program & 12.4 & 2.3 & 3.4 & 36.0 & 28.0 & 0.0 & 7.7 \\
\hline Amortization & -245.1 & -268.2 & -258.8 & -292.7 & -233.6 & -259.7 & -174.5 \\
\hline Net change in arrears & 37.6 & 338.3 & 262.5 & 282.6 & 104.5 & 210.8 & 167.3 \\
\hline Debt rescheduling & 175.8 & 85.7 & 68.8 & 2.8 & 11.6 & 4.3 & 1.4 \\
\hline
\end{tabular}


Table 26. Republic of Congo: Balance of Payments, 1996-2002 1/ (concluded)

\begin{tabular}{|c|c|c|c|c|c|c|c|}
\hline & 1997 & 1998 & 1999 & 2000 & 2001 & $\begin{array}{r}2002 \\
\text { Est. }\end{array}$ & $\begin{array}{c}2003 \\
\text { Prel. }\end{array}$ \\
\hline & \multicolumn{7}{|c|}{ (In billions of CFA francs) } \\
\hline Private sector & -57.6 & -18.5 & -420.6 & -153.0 & -162.4 & -82.1 & -81.6 \\
\hline Oil sector & 0.4 & 26.6 & 139.4 & 0.0 & 41.5 & 38.6 & 34.4 \\
\hline Non-oil sector & -58.0 & -45.1 & -560.0 & -153.0 & -203.9 & -120.7 & -116.1 \\
\hline Short term & -1.8 & 97.6 & 291.8 & -259.2 & -55.4 & -237.3 & -123.4 \\
\hline Public & 0.0 & 51.0 & 0.0 & 0.0 & 12.7 & 12.7 & 6.4 \\
\hline Private & -1.8 & 46.6 & 291.8 & -259.2 & -68.2 & -250.0 & -129.8 \\
\hline Oil sector & 2.2 & 0.6 & 245.3 & -242.2 & -86.0 & -200.0 & -103.8 \\
\hline Non-oil sector & -3.9 & 46.0 & 46.5 & -17.0 & 17.8 & -50.0 & -26.0 \\
\hline Of which: commercial banks & -4.3 & 15.4 & -3.9 & -26.8 & 20.4 & -35.8 & 37.5 \\
\hline Errors and omissions & -13.4 & -94.4 & 13.5 & -41.1 & -1.8 & -49.4 & 0.0 \\
\hline Overall balance of payments & -11.6 & -46.4 & 36.7 & 120.1 & -104.4 & -24.8 & 10.6 \\
\hline Financing & 11.6 & 46.4 & -36.7 & -120.1 & 104.4 & 24.8 & -10.6 \\
\hline Reserve financing & 11.6 & 46.4 & -36.7 & -120.1 & 104.4 & 24.8 & -10.6 \\
\hline IMF (net) & -1.3 & -0.5 & -2.6 & 9.9 & -0.9 & -6.0 & -5.2 \\
\hline Purchases & 0.0 & 5.8 & 0.0 & 9.9 & 0.0 & 0.0 & 0.0 \\
\hline Repurchases & -1.3 & -6.3 & -2.6 & 0.0 & -0.9 & -6.0 & -5.2 \\
\hline Other reserves & 6.0 & 61.3 & -43.2 & -136.9 & 124.0 & -17.1 & 26.8 \\
\hline Financing gap & 0.0 & 0.0 & 0.0 & 0.0 & 0.0 & 0.0 & 0.0 \\
\hline Memorandum items: & \multicolumn{7}{|c|}{ (In percent of GDP, unless otherwise indicated) } \\
\hline \multicolumn{8}{|l|}{ Current account } \\
\hline Excluding public transfers & -13.2 & -21.0 & -17.2 & 7.6 & -3.4 & -0.5 & 0.2 \\
\hline Oil sector & 8.4 & 9.9 & 7.4 & 14.0 & 12.5 & 26.3 & 19.3 \\
\hline Non-oil sector & -21.4 & -30.4 & -24.3 & -6.7 & -15.8 & -26.8 & -19.1 \\
\hline Including public transfers & -12.9 & -20.6 & -17.1 & 7.9 & -3.2 & -0.3 & 0.4 \\
\hline Capital account & 15.6 & 2.7 & 1.0 & 0.6 & 3.4 & 0.5 & 0.4 \\
\hline Gross reserves (in billions of CFA francs) & 37.8 & 2.3 & 27.8 & 158.6 & 53.6 & 22.2 & 21.4 \\
\hline In months of imports of goods & 0.6 & 0.0 & 0.4 & 1.9 & 0.6 & 0.2 & 0.2 \\
\hline GDP (in billions of CFA francs) & $1,355.7$ & $1,150.1$ & $1,449.3$ & $2,292.5$ & $2,043.4$ & $2,103.0$ & $2,040.0$ \\
\hline \multicolumn{8}{|l|}{ CFA francs per U.S. dollar } \\
\hline Average & 803.2 & 800.2 & 841.9 & 939.0 & 933.2 & 902.5 & 811.1 \\
\hline End-of-period & 807.9 & 791.6 & 896.2 & 918.5 & 935.4 & 850.4 & 755.7 \\
\hline
\end{tabular}

Sources: Bank of Central African States (BEAC); and staff estimates.

1/ Data being revised extensively. 
Table 27. Republic of Congo: Balance of Payments of the Oil and Non-Oil Sectors, 1999-2003 1/

\begin{tabular}{|c|c|c|c|c|c|c|c|c|c|c|}
\hline & \multicolumn{2}{|c|}{1999} & \multicolumn{2}{|c|}{2000} & \multicolumn{2}{|c|}{2001} & \multicolumn{2}{|c|}{2002} & \multicolumn{2}{|c|}{2003} \\
\hline & $\begin{array}{c}\text { Oil } \\
\text { sector }\end{array}$ & $\begin{array}{l}\text { Non-oil } \\
\text { sector }\end{array}$ & $\begin{array}{l}\text { Oil } \\
\text { sector }\end{array}$ & $\begin{array}{l}\text { Non-oil } \\
\text { sector }\end{array}$ & $\begin{array}{c}\text { Oil } \\
\text { sector }\end{array}$ & $\begin{array}{l}\text { Non-oil } \\
\text { sector }\end{array}$ & $\begin{array}{c}\text { Oil } \\
\text { sector }\end{array}$ & $\begin{array}{l}\text { Non-oil } \\
\text { sector }\end{array}$ & $\begin{array}{c}\text { Oil } \\
\text { sector }\end{array}$ & $\begin{array}{l}\text { Non-oil } \\
\text { sector }\end{array}$ \\
\hline & \multicolumn{10}{|c|}{ (In billions of CFA francs) } \\
\hline Current account & 106.6 & -355.0 & 321.1 & -139.1 & 255.9 & -320.5 & 554.0 & -561.0 & 393.4 & -385.8 \\
\hline Trade balance & 831.0 & -194.8 & $1,562.9$ & -243.2 & $1,162.1$ & -155.0 & $1,303.7$ & -228.6 & $1,155.5$ & -151.7 \\
\hline Exports, f.o.b. & 879.6 & 78.5 & $1,633.2$ & 110.6 & $1,341.4$ & 165.2 & $1,373.8$ & 193.5 & $1,225.7$ & 249.9 \\
\hline Imports, f.o.b. & -48.6 & -273.2 & -70.3 & -353.9 & -179.3 & -320.2 & -70.1 & -422.1 & -70.1 & -401.6 \\
\hline Services, net & -388.5 & -56.4 & -381.9 & -96.6 & -358.8 & -104.1 & -352.4 & -161.6 & -352.3 & -140.5 \\
\hline Balance on goods, services, and income & 442.5 & -251.1 & $1,181.0$ & -339.8 & 803.3 & -259.0 & 951.3 & -390.2 & 803.2 & -292.2 \\
\hline Income & -335.9 & -100.6 & -859.9 & 187.3 & -547.5 & -63.8 & -397.3 & -173.4 & -409.8 & -97.4 \\
\hline Current transfers, net & 0.0 & -3.3 & 0.0 & 13.4 & 0.0 & 2.3 & 0.0 & 2.7 & 0.0 & 3.8 \\
\hline Capital account & 0.0 & 14.9 & 0.0 & 14.3 & 0.0 & 69.2 & 0.0 & 10.7 & 0.0 & 8.5 \\
\hline Financial account & 100.4 & 156.3 & -90.7 & 55.6 & -28.6 & -78.6 & 147.9 & -127.1 & -6.5 & 1.0 \\
\hline Direct investment & 0.0 & 319.5 & 0.0 & 340.2 & 0.0 & 160.0 & 0.0 & 156.6 & 0.0 & 187.4 \\
\hline Portfolio investment & 0.0 & -10.9 & 0.0 & 0.2 & 0.0 & -5.3 & 0.0 & -5.9 & 0.0 & -3.7 \\
\hline Other investment & 100.4 & -152.3 & -90.7 & -284.8 & -28.6 & -233.4 & 147.9 & -277.9 & -6.5 & -182.8 \\
\hline Medium and long term & -144.9 & -198.8 & 151.5 & -267.8 & 57.3 & -263.9 & 347.9 & -240.6 & 98.6 & -164.4 \\
\hline Short term & 245.3 & 46.5 & -242.2 & -17.0 & -86.0 & 30.5 & -200.0 & -37.3 & -105.0 & -18.4 \\
\hline Errors and omissions & 0.0 & 13.5 & 0.0 & -41.1 & 0.0 & -1.8 & 0.0 & -49.4 & 0.0 & 0.0 \\
\hline Overall balance & 207.0 & -170.3 & 230.4 & -110.3 & 227.3 & -331.7 & 702.0 & -726.8 & 386.9 & -376.3 \\
\hline Memorandum items: & \multicolumn{10}{|c|}{ (In percent of GDP) } \\
\hline Exports & 60.7 & 5.4 & 71.2 & 4.8 & 65.6 & 8.1 & 65.3 & 9.2 & 60.1 & 12.2 \\
\hline Imports & -3.4 & -18.9 & -3.1 & -15.4 & -8.8 & -15.7 & -3.3 & -20.1 & -3.4 & -19.7 \\
\hline Services, net & -26.8 & -3.9 & -16.7 & -4.2 & -17.6 & -5.1 & -16.8 & -7.7 & -17.3 & -6.9 \\
\hline Current account & 7.4 & -24.5 & 14.0 & -6.1 & 12.5 & -15.7 & 26.3 & -26.7 & 19.3 & -18.9 \\
\hline Capital account & 0.0 & 1.0 & 0.0 & 0.6 & 0.0 & 3.4 & 0.0 & 0.5 & 0.0 & 0.4 \\
\hline Overall balance & 14.3 & -11.7 & 10.0 & -4.8 & 11.1 & -16.2 & 33.4 & -34.6 & 19.0 & -18.4 \\
\hline
\end{tabular}

Sources: Bank of Central African States (BEAC); and staff estimates.

$1 /$ Data being revised extensively. 
Table 28. Republic of Congo: Composition of Exports, 1997-2003

(In billions of CFA francs, unless otherwise indicated)

\begin{tabular}{|c|c|c|c|c|c|c|c|}
\hline & 1997 & 1998 & 1999 & 2000 & 2001 & $\begin{array}{r}2002 \\
\text { Est. }\end{array}$ & $\begin{array}{c}2003 \\
\text { Prel. }\end{array}$ \\
\hline Total exports, f.o.b. & 967.1 & 808.0 & 958.0 & $1,743.8$ & $1,506.6$ & $1,567.3$ & $1,475.6$ \\
\hline Oil & 769.6 & 708.2 & 879.6 & $1,633.2$ & $1,341.4$ & $1,373.8$ & $1,225.7$ \\
\hline Non-oil & 197.5 & 99.8 & 78.5 & 110.6 & 165.2 & 193.5 & 249.9 \\
\hline Crude oil & 763.6 & 707.5 & 878.8 & $1,619.3$ & $1,287.6$ & $1,375.7$ & $1,109.8$ \\
\hline Volume (millions of tons) & 11.5 & 12.5 & 13.0 & 12.9 & 11.1 & 11.6 & 11.1 \\
\hline Unit value (thousands of CFA francs per ton) & 66.4 & 56.6 & 67.6 & 125.5 & 116.0 & 118.8 & 112.3 \\
\hline WEO oil price (U.S. dollar per barrel) & 19.3 & 13.1 & 18.0 & 28.2 & 24.3 & 25.0 & 29.0 \\
\hline Congolese oil export price (U.S. dollar per barrel) & 17.6 & 11.3 & 16.8 & 26.2 & 21.9 & 23.0 & 27.4 \\
\hline Refined products & 5.6 & 0.6 & 0.6 & 13.7 & 3.3 & 17.5 & 0.0 \\
\hline Volume (millions of tons) & 0.1 & 0.0 & 0.0 & 0.2 & 0.1 & 0.2 & 0.0 \\
\hline Unit value (CFA francs per ton) & 70.0 & 70.0 & 70.0 & 83.4 & 55.1 & 75.8 & 69.1 \\
\hline Wood & 41.5 & 83.3 & 51.9 & 67.8 & 97.0 & 124.5 & 176.6 \\
\hline Volume (thousands of cubic meters) & 558.2 & 693.1 & 756.7 & 720.2 & 874.4 & 982.8 & $1,433.4$ \\
\hline Unit value (CFA francs per cubic meter) & 74.4 & 120.2 & 68.5 & 94.1 & 111.0 & 126.6 & 123.2 \\
\hline Sugar & 8.7 & 6.5 & 6.5 & 9.0 & 10.5 & 10.6 & 12.6 \\
\hline Volume (tons) & 33.0 & 27.6 & 21.7 & 30.4 & 33.8 & 33.2 & 33.2 \\
\hline Unit value (CFA francs per kilogram) & 264.4 & 236.0 & 300.2 & 295.6 & 310.0 & 319.7 & 379.0 \\
\hline Other, value & 147.2 & 10.0 & 20.1 & 33.9 & 57.7 & 58.4 & 60.7 \\
\hline
\end{tabular}

Sources: Congolese authorities; and staff estimates. 
Table 29. Republic of Congo: Services, Income, and Transfers, 1997-2003 1/

(In billions of CFA francs)

\begin{tabular}{|c|c|c|c|c|c|c|c|}
\hline & 1997 & 1998 & 1999 & 2000 & 2001 & $\begin{array}{r}2002 \\
\text { Est. }\end{array}$ & $\begin{array}{c}2003 \\
\text { Prel. }\end{array}$ \\
\hline Services & -378.7 & -436.4 & -444.9 & -478.5 & -462.8 & -514.0 & -492.8 \\
\hline Oil & -302.0 & -391.5 & -388.5 & -381.9 & -358.8 & -352.4 & -352.3 \\
\hline Non-oil & -76.6 & -45.0 & -56.4 & -96.6 & -104.1 & -161.6 & -140.5 \\
\hline Credit & 58.2 & 69.4 & 89.9 & 97.2 & 129.7 & 129.1 & 132.4 \\
\hline Transport, insurance and other services & 52.9 & 64.5 & 82.2 & 88.5 & 113.7 & 119.4 & 122.7 \\
\hline Travel & 5.3 & 4.9 & 7.7 & 8.6 & 16.0 & 9.7 & 9.7 \\
\hline Debit & -436.9 & -505.8 & -534.8 & -575.7 & -592.5 & -643.2 & -625.2 \\
\hline Transport, insurance and other services & -398.8 & -474.2 & -496.0 & -540.4 & -571.6 & -619.1 & -601.2 \\
\hline Travel & -38.1 & -31.6 & -38.8 & -35.3 & -20.9 & -24.0 & -24.0 \\
\hline Income (net) & -386.1 & -277.3 & -436.5 & -672.6 & -611.3 & -570.7 & -507.2 \\
\hline Oil & -199.6 & -121.4 & -289.7 & -517.3 & -428.5 & -397.3 & -409.8 \\
\hline Non-oil & -187.4 & -156.4 & -146.8 & -155.3 & -182.7 & -173.4 & -97.4 \\
\hline Labor income & -369.9 & -260.6 & -417.3 & -656.0 & -592.0 & -549.0 & -494.0 \\
\hline Investment income & -16.2 & -16.7 & -19.2 & -16.6 & -19.2 & -21.7 & -13.2 \\
\hline Transfers (net) & 1.2 & -1.8 & -3.3 & 13.4 & 2.3 & 2.7 & 3.8 \\
\hline Private & -2.4 & -6.3 & -3.6 & 5.0 & -1.9 & -1.7 & -0.6 \\
\hline Oil sector & -3.1 & -7.7 & -8.2 & -9.9 & 5.3 & -4.9 & 0.0 \\
\hline Non-oil sector & 0.7 & 1.3 & 4.5 & 14.9 & -7.2 & 3.2 & -0.6 \\
\hline Public & 3.6 & 4.5 & 0.4 & 8.4 & 4.2 & 4.4 & 4.3 \\
\hline
\end{tabular}

Sources: Bank of Central African States (BEAC); and staff estimates.

1/ Data being revised extensively. 
Table 30. Republic of Congo: Capital and Financial Accounts, 1997-2003

(In billions of CFA francs)

\begin{tabular}{|c|c|c|c|c|c|c|c|}
\hline & 1997 & 1998 & 1999 & 2000 & 2001 & $\begin{array}{r}2002 \\
\text { Est. }\end{array}$ & $\begin{array}{c}2003 \\
\text { Prel. }\end{array}$ \\
\hline Capital account & 211.4 & 31.3 & 14.9 & 14.3 & 69.2 & 10.7 & 8.5 \\
\hline Government grants & 1.4 & 3.6 & 6.3 & 6.8 & 3.7 & 3.7 & 9.9 \\
\hline Debt cancellation & 203.3 & 27.7 & 8.6 & 6.5 & 63.6 & 6.4 & -2.6 \\
\hline Current debt service cancelled & 67.0 & 27.7 & 8.6 & 6.5 & 4.7 & 6.4 & -2.6 \\
\hline Arrears cancelled & 136.4 & 0.0 & 0.0 & 0.0 & 58.9 & 0.0 & 0.0 \\
\hline Other & 6.7 & 0.0 & 0.0 & 1.0 & 1.9 & 0.7 & 1.2 \\
\hline Oil sector & 0.0 & 0.0 & 0.0 & 0.0 & 0.0 & 0.0 & 0.0 \\
\hline Non-oil sector & 6.7 & 0.0 & 0.0 & 1.0 & 1.9 & 0.7 & 1.2 \\
\hline Financial account & -34.3 & 253.7 & 256.7 & -35.1 & -107.2 & 20.8 & -5.5 \\
\hline Direct investment (net) & 44.2 & 24.1 & 319.5 & 340.2 & 160.0 & 156.6 & 187.4 \\
\hline Oil sector & 39.9 & 43.3 & 306.9 & 286.9 & 152.1 & 147.8 & 150.9 \\
\hline Non-oil sector & 4.2 & -19.2 & 12.6 & 53.3 & 7.9 & 8.8 & 36.5 \\
\hline Portfolio investment & -3.0 & -7.5 & -10.9 & 0.2 & -5.3 & -5.9 & -3.7 \\
\hline Other investment & -75.5 & 237.1 & -51.9 & -375.5 & -262.0 & -129.9 & -189.2 \\
\hline Medium and long term & -73.7 & 139.5 & -343.7 & -116.4 & -206.5 & 107.3 & -65.9 \\
\hline Public sector & -16.1 & 158.0 & 76.8 & 36.6 & -44.1 & 189.4 & 15.8 \\
\hline Drawings & 15.6 & 2.3 & 4.3 & 44.0 & 73.4 & 234.1 & 21.6 \\
\hline Amortization & -245.1 & -268.2 & -258.8 & -292.7 & -233.6 & -259.7 & -174.5 \\
\hline Change in arrears & 37.6 & 338.3 & 262.5 & 282.6 & 104.5 & 210.8 & 167.3 \\
\hline Debt rescheduling & 175.8 & 85.7 & 68.8 & 2.8 & 11.6 & 4.3 & 1.4 \\
\hline Private sector & -57.6 & -18.5 & -420.6 & -153.0 & -162.4 & -82.1 & -81.6 \\
\hline Drawings & 2.5 & 32.6 & 144.2 & 4.8 & 45.6 & 42.7 & 39.7 \\
\hline Of which: oil sector & 0.4 & 26.6 & 139.4 & 0.0 & 41.5 & 38.6 & 34.4 \\
\hline Amortization & -60.6 & -51.3 & -564.4 & -157.7 & -208.0 & -124.9 & -121.3 \\
\hline Of which: oil sector & -59.4 & -47.8 & -559.8 & -132.8 & -200.0 & -115.7 & -103.3 \\
\hline Other private investments & 0.5 & 0.3 & -0.3 & -0.1 & 0.1 & 0.1 & 0.0 \\
\hline Short term & -1.8 & 97.6 & 291.8 & -259.2 & -55.4 & -237.3 & -123.4 \\
\hline Public sector & 0.0 & 51.0 & 0.0 & 0.0 & 12.7 & 12.7 & 6.4 \\
\hline Drawings & 0.0 & 51.0 & 0.0 & 0.0 & 0.0 & 10.2 & 2.6 \\
\hline Amortization & 0.0 & 0.0 & 0.0 & 0.0 & 0.3 & 0.1 & 0.1 \\
\hline Other & 0.0 & 0.0 & 0.0 & 0.0 & 12.5 & 2.5 & 5.0 \\
\hline Private sector & -1.8 & 46.6 & 291.8 & -259.2 & -68.2 & -250.0 & -129.8 \\
\hline
\end{tabular}

Sources: Congolese authorities; and staff estimates. 
Table 31. Republic of Congo: External Trade Indices, 1997-2003

(Index, 1990=100, unless otherwise indicated)

\begin{tabular}{|c|c|c|c|c|c|c|c|}
\hline & 1997 & 1998 & 1999 & 2000 & 2001 & $\begin{array}{r}2002 \\
\text { Est. }\end{array}$ & $\begin{array}{c}2003 \\
\text { Prel. }\end{array}$ \\
\hline \multicolumn{8}{|l|}{ Total exports, f.o.b. } \\
\hline Value index & 255.8 & 213.7 & 253.4 & 461.3 & 398.5 & 414.6 & 390.3 \\
\hline In percent change & 14.3 & -16.5 & 18.6 & 82.0 & -13.6 & 4.0 & -5.9 \\
\hline Volume index & 143.0 & 155.1 & 165.8 & 166.2 & 138.1 & 149.8 & 142.8 \\
\hline In percent change & 14.2 & 8.5 & 6.9 & 0.2 & -16.9 & 8.4 & -4.7 \\
\hline Unit value index & 178.9 & 137.8 & 152.8 & 277.6 & 288.5 & 276.8 & 273.3 \\
\hline In percent change & 0.0 & -23.0 & 10.9 & 81.6 & 3.9 & -4.0 & -1.2 \\
\hline \multicolumn{8}{|l|}{ Crude oil } \\
\hline Value index & 252.5 & 234.0 & 290.6 & 535.5 & 425.8 & 455.0 & 413.1 \\
\hline In percent change & 4.2 & -7.3 & 24.2 & 84.3 & -20.5 & 6.8 & -9.2 \\
\hline Volume index & 153.8 & 167.2 & 173.9 & 172.5 & 148.5 & 154.9 & 141.8 \\
\hline In percent change & 15.0 & 8.7 & 4.0 & -0.8 & -14.0 & 4.3 & -8.5 \\
\hline Unit value index & 164.2 & 140.0 & 167.2 & 310.4 & 286.8 & 293.8 & 291.4 \\
\hline In percent change & -9.4 & -14.8 & 19.4 & 85.7 & -7.6 & 2.4 & -0.8 \\
\hline \multicolumn{8}{|l|}{ Refined products } \\
\hline Value index & 58.3 & 5.8 & 5.8 & 142.9 & 34.1 & 182.3 & $\ldots$ \\
\hline In percent change & -15.2 & -90.0 & 0.0 & $2,352.9$ & -76.1 & 434.6 & \\
\hline Volume index & 24.8 & 2.5 & 2.5 & 51.1 & 18.4 & 71.7 & $\ldots$ \\
\hline In percent change & -46.7 & -90.0 & 0.0 & $1,958.8$ & -63.9 & 288.6 & \\
\hline Unit value index & 234.9 & 234.9 & 234.9 & 279.9 & 184.9 & 254.4 & $\ldots$ \\
\hline In percent change & 59.1 & 0.0 & 0.0 & 19.1 & -33.9 & 37.6 & $\ldots$ \\
\hline \multicolumn{8}{|l|}{ Non-oil products } \\
\hline Value index & 261.0 & 131.9 & 103.7 & 146.2 & 218.3 & 255.7 & 330.2 \\
\hline In percent change & 91.4 & -49.5 & -21.4 & 41.0 & 49.3 & 17.1 & 29.2 \\
\hline Volume index & 104.6 & 70.8 & 77.1 & 87.3 & 102.4 & 105.5 & 134.5 \\
\hline In percent change & 42.6 & -32.4 & 8.9 & 13.3 & 17.2 & 3.1 & 27.4 \\
\hline Unit value index & 249.4 & 186.4 & 134.5 & 167.4 & 213.3 & 242.3 & 245.6 \\
\hline In percent change & 34.3 & -25.3 & -27.8 & 24.5 & 27.4 & 13.6 & 1.4 \\
\hline \multicolumn{8}{|l|}{ Wood } \\
\hline Value index & 94.4 & 189.3 & 117.8 & 154.0 & 220.5 & 282.9 & 401.4 \\
\hline In percent change & 12.9 & 100.5 & -37.7 & 30.7 & 43.2 & 28.3 & 41.9 \\
\hline Volume index & 48.3 & 60.0 & 65.5 & 62.3 & 75.7 & 85.1 & 124.1 \\
\hline In percent change & 1.0 & 24.2 & 9.2 & -4.8 & 21.4 & 12.4 & 45.8 \\
\hline Unit value index & 195.4 & 315.5 & 179.9 & 247.0 & 291.3 & 332.4 & 323.4 \\
\hline In percent change & 11.8 & 61.5 & -43.0 & 37.3 & 17.9 & 14.1 & -2.7 \\
\hline
\end{tabular}


Table 31. Republic of Congo: External Trade Indices, 1997-2003 (concluded)

(Index, 1990 $=100$, unless otherwise indicated)

\begin{tabular}{|c|c|c|c|c|c|c|c|}
\hline & 1997 & 1998 & 1999 & 2000 & 2001 & $\begin{array}{r}2002 \\
\text { Est. }\end{array}$ & $\begin{array}{c}2003 \\
\text { Prel. }\end{array}$ \\
\hline \multicolumn{8}{|l|}{ Sugar } \\
\hline Value index & 466.6 & 348.3 & 348.0 & 480.5 & 560.0 & 567.6 & 672.9 \\
\hline In percent change & 43.9 & -25.3 & -0.1 & 38.1 & 16.5 & 1.4 & 18.6 \\
\hline Volume index & 183.3 & 153.3 & 120.4 & 168.9 & 187.7 & 184.4 & 184.4 \\
\hline In percent change & 52.1 & -16.4 & -21.5 & 40.2 & 11.1 & -1.7 & 0.0 \\
\hline Unit value index & 254.5 & 227.2 & 289.0 & 284.5 & 298.4 & 307.7 & 364.8 \\
\hline In percent change & -5.4 & -10.7 & 27.2 & -1.5 & 4.9 & 3.1 & 18.6 \\
\hline \multicolumn{8}{|l|}{ Other } \\
\hline Value index & 317.9 & 21.6 & 43.4 & 73.2 & 124.6 & 126.1 & 131.1 \\
\hline In percent change & 144.1 & -93.2 & 101.0 & 68.7 & 70.2 & 1.2 & 3.9 \\
\hline Volume index & 115.8 & 106.7 & 93.0 & 115.6 & 131.7 & 134.8 & 154.3 \\
\hline In percent change & 37.6 & -7.9 & -12.8 & 24.4 & 13.9 & 2.3 & 14.5 \\
\hline Unit value index & 274.5 & 20.2 & 46.7 & 63.3 & 94.6 & 93.6 & 85.0 \\
\hline In percent change & 77.5 & -92.6 & 130.6 & 35.6 & 49.4 & -1.1 & -9.2 \\
\hline Terms of trade index & 85.6 & 63.2 & 86.9 & 134.5 & 120.2 & 119.9 & 122.3 \\
\hline In percent change & 2.9 & -26.2 & 37.4 & 54.9 & -10.7 & -0.3 & 2.0 \\
\hline Terns of trade index, excluding oil & 128.4 & 80.3 & 73.0 & 80.1 & 77.9 & 125.3 & 152.7 \\
\hline In percent change & 59.9 & -37.5 & -9.1 & 9.8 & -2.8 & 60.9 & 21.9 \\
\hline
\end{tabular}

Sources: Congolese authorities; and staff estimates. 
Table 32. Republic of Congo: External Public Debt and Debt Service, 1997-2003

\begin{tabular}{|c|c|c|c|c|c|c|c|}
\hline & 1997 & 1998 & 1999 & 2000 & 2001 & $\begin{array}{r}2002 \\
\text { Est. }\end{array}$ & $\begin{array}{l}2003 \\
\text { Prel. }\end{array}$ \\
\hline & \multicolumn{7}{|c|}{ (In billions of CFA francs) } \\
\hline Total medium- and long-term debt outstanding & $2,982.4$ & $3,041.4$ & $3,357.0$ & $3,741.9$ & $4,010.3$ & $3,767.3$ & $3,766.9$ \\
\hline Of which: arrears & 678.6 & $1,016.9$ & $1,279.4$ & $1,793.5$ & $2,282.6$ & $2,242.5$ & $2,405.6$ \\
\hline Total medium- and long-term debt & & & & & & & \\
\hline outstanding (excluding IMF) & $2,962.3$ & $3,022.2$ & $3,338.1$ & $3,712.8$ & $3,981.5$ & $3,744.4$ & $3,749.1$ \\
\hline Multilateral creditors & 348.4 & 356.3 & 397.9 & 421.4 & 376.6 & 382.3 & 366.3 \\
\hline Paris Club creditors & $1,730.4$ & $1,810.3$ & $1,976.9$ & $2,104.8$ & $2,231.1$ & $2,116.8$ & $2,173.2$ \\
\hline Other official creditors & 137.9 & 136.9 & 154.0 & 206.2 & 152.6 & 141.8 & 142.5 \\
\hline Commercial banks & 333.7 & 330.3 & 347.3 & 547.5 & 852.0 & 726.6 & 726.6 \\
\hline Collateralized debt & 351.9 & 330.7 & 353.1 & 319.9 & 247.5 & 258.2 & 220.7 \\
\hline Other private creditors & 60.0 & 57.8 & 108.9 & 113.0 & 121.6 & 118.7 & 119.6 \\
\hline Outstanding IMF credit & 20.1 & 19.1 & 18.9 & 29.1 & 28.8 & 22.9 & 17.8 \\
\hline Debt service due & 410.7 & 423.3 & 412.5 & 442.3 & 379.6 & 389.1 & 269.6 \\
\hline Principal & 246.4 & 274.5 & 261.4 & 292.7 & 234.5 & 265.7 & 179.7 \\
\hline Interest & 164.3 & 148.9 & 151.1 & 149.6 & 145.1 & 123.3 & 89.9 \\
\hline Multilateral (including IMF) & 43.0 & 49.4 & 46.5 & 49.3 & 42.7 & 44.5 & 35.7 \\
\hline Bilateral & 277.8 & 270.9 & 251.1 & 235.0 & 192.2 & 177.5 & 168.4 \\
\hline Commercial banks & 1.3 & 1.6 & 5.6 & 7.4 & 0.0 & 0.0 & 0.0 \\
\hline Collateralized debt & 95.2 & 100.9 & 102.9 & 134.9 & 129.3 & 151.4 & 54.4 \\
\hline Other & -6.6 & 0.5 & 6.4 & 15.7 & 15.5 & 15.7 & 11.1 \\
\hline Debt rescheduling & 175.8 & 85.7 & 68.8 & 2.8 & 11.6 & 4.3 & 1.4 \\
\hline Debt service & 78.6 & 53.0 & 55.9 & 1.2 & 3.3 & 4.3 & 1.4 \\
\hline Arrears & 97.2 & 32.7 & 12.9 & 1.6 & 8.3 & 0.0 & 0.0 \\
\hline Debt cancellation & 203.3 & 27.7 & 8.6 & 6.5 & 63.6 & 6.4 & 0.1 \\
\hline Debt service due after debt relief & 265.1 & 342.7 & 348.0 & 434.6 & 371.6 & 378.4 & 268.1 \\
\hline Principal & 157.8 & 200.9 & 197.0 & 285.9 & 227.8 & 262.2 & 178.2 \\
\hline Interest & 107.3 & 141.8 & 151.0 & 148.7 & 143.8 & 116.2 & 89.9 \\
\hline
\end{tabular}


Table 33. Republic of Congo: Exchange Rate Indices, 1997-2003

(Index, $1990=100)$

\begin{tabular}{|c|c|c|}
\hline & $\begin{array}{l}\text { Real Effective } \\
\text { Exchange Rate }\end{array}$ & $\begin{array}{c}\text { Nominal Effective } \\
\text { Exchange Rate }\end{array}$ \\
\hline 1997 & 81.70 & 64.62 \\
\hline I & 75.77 & 65.12 \\
\hline II & 76.42 & 64.49 \\
\hline III & 84.60 & 63.68 \\
\hline IV & 90.01 & 65.17 \\
\hline 1998 & 83.49 & 65.72 \\
\hline I & 85.04 & 64.94 \\
\hline II & 82.49 & 65.33 \\
\hline III & 81.51 & 66.10 \\
\hline IV & 84.90 & 66.50 \\
\hline 1999 & 83.93 & 64.84 \\
\hline I & 85.42 & 65.97 \\
\hline II & 83.59 & 64.85 \\
\hline III & 83.59 & 64.56 \\
\hline IV & 83.11 & 63.97 \\
\hline 2000 & 78.96 & 61.94 \\
\hline I & 83.94 & 62.93 \\
\hline II & 80.10 & 62.02 \\
\hline III & 77.15 & 61.62 \\
\hline IV & 74.63 & 61.20 \\
\hline 2001 & 78.62 & 62.59 \\
\hline I & 77.16 & 62.74 \\
\hline II & 77.73 & 62.13 \\
\hline III & 79.02 & 62.62 \\
\hline IV & 80.57 & 62.86 \\
\hline 2002 & 81.56 & 63.97 \\
\hline I & 80.22 & 62.54 \\
\hline II & 82.08 & 63.34 \\
\hline III & 81.48 & 64.53 \\
\hline IV & 82.46 & 65.49 \\
\hline 2003 & 83.53 & 66.72 \\
\hline I & 82.49 & 66.29 \\
\hline II & 82.56 & 67.02 \\
\hline III & 83.05 & 66.73 \\
\hline IV & 86.01 & 66.82 \\
\hline
\end{tabular}

Source: IMF, Information Notice System. 
Republic of Congo: Summary of Tax System, 2004

\section{Taxes}

Scope
Exemptions
Rate

Taxable Base

\section{Taxes on income}

1.1 Personal income tax (impôt sur le revenu des personnes physiques (IRPP)).
Individuals, irrespective of nationality, resident in Congo for tax purposes and individuals not domiciled in Congo but earning income there.
Individuals whose net income is less than CFAF 200,000.

\subsubsection{Real estate income tax (impôt sur les revenus fonciers).}

Income from improved or unimproved property; fees pertaining to rights of ownership; concession of carrier exploitation rights; lease of advertising rights.

\author{
1.1.2 Tax on \\ wages, \\ salaries, \\ pensions, and \\ annuities \\ (impôt sur les \\ traitements, \\ salaires, \\ pensions et \\ rentes \\ viagères).
}

Salaries, allowances, remittances, gratuities, wages, fees, pensions, and annuities.

\section{Real estate not leased,} or occupied free of charge by descendants or forebears.

Allowances intended to defray expenses related to a job or employment, family allowances, unemployment benefits, and war pensions.

\begin{tabular}{lr}
\multicolumn{1}{c}{$\begin{array}{c}\text { Income } \\
\text { (CFA francs) } \\
\text { (Percent) }\end{array}$} \\
$200,000<800,000$ & 15 \\
$800,000<2,500,000$ & 30 \\
$2,500,000<8,000,000$ & 45 \\
Over $8,000,000$ & 50
\end{tabular}

Income split system, with a maximum of 6.5 shares: the taxpayer's family situation is taken into account splitting income into parts (quotient familial); one part for the taxpayer; one part for the spouse; and one-half of a part for each dependent child up to a limit of nine.

As indicated in 1.1

Rents collected, with a deduction of 30 percent; 95 percent of advertising revenue is taxed.

As indicated in 1.1

Income collected with a lump-sum deduction of 20 percent.

Including benefits in kind. 
Republic of Congo: Summary of Tax System, 2004

Taxes

1.1.3 Tax on industrial, commercial, and agricultural earnings (impôt sur les bénéfices industriels, commerciaux et agricoles).
Profits from commercial, Profits from a new industrial, artisanal, or agricultural operations; profits from lease of furnished rooms. entity (enterprise or plantation, for the first two fiscal years).
Income earned by attorneys, notaries/solicitors, and architects.
As indicated in 1.1

As in indicated in 1.1

Salaries and lump-sum payments granted to directors (with majority shareholdings) of limited liability corporations (SARLs) or the managers of limited equity partnerships.

As indicated in 1.1

\section{Income from \\ As indicated in 1.1} agricultural credit unions. Interest on treasury securities.

1.1 .5 Tax on
compensation
earned by
directors with
majority
shareholdings
(impôt sur les
rémunérations
des gérants
majoritaires).
Proceeds from stocks, shares, bonds, deposits, other claims, and profit- sharing schemes.
1.1.6
Investment income tax (impôt sur les revenus des capitaux mobiliers).
As indicated in 1.1

Taxable Base

Net profit $=$ difference between net asset value at the beginning and end of the period. Presumptive earnings for those taxpayers with turnover not exceeding the following limits: CFAF 30 million for sales, CFAF 20 million for craftsmen, and CFAF 10 million for the rendering of services.

Profit $=$ surplus of total receipts over business expenses. Profit calculated with a lumpsum deduction for those taxpayers whose total gross income is less than CFAF 10 million.

Compensation earned after deduction of business-operating expenses actually incurred by the beneficiary.

The entire amount of income distributed or earned. 
Republic of Congo: Summary of Tax System, 2004

Taxes

1.1.7 Capital gains tax on real estate (impôt sur les plus-values immobilières).

1.2 Corporate income tax (impôt sur les sociétés).

1.3 Withholding tax on income from securities (impôt sur le revenu des valeurs mobilières). This tax represents an advance payment on the IRPP category of "investment income."

\subsection{Tax on real} estate income (taxe immobilière sur les loyers). This tax is deductible from the IRPP.
Capital gains realized upon the sale or exchange of real estate, whether improved or unimproved.
10 percent for local governments. 15 percent for Treasury.

Business corporations, cooperatives, and public entities and government agencies with financial autonomy; commercial activities of noncommercial companies and private clubs.

Dividends and other income from equities; interest and profits from shares in partnerships.

\section{Agriculture} cooperatives, and public low-cost housing providers,

Agricultural credit unions.

New companies (For the first two fiscal years, under certain conditions).

Income from government securities; shares in partnerships subject to real estate tax.
30 percent, for agriculture and housing companies.

35 percent for nonoilforeign-owned companies. 38 percent for all the other companies.
20 percent, 22 percent, or 30 percent, depending on the type of income involved.
Income from improved or unimproved property.
Embassies.

One-twelfth of rents.
Difference between the sales price and the purchase price/ construction cost with a deduction of 3 percent (unimproved property) or 5 percent (improved property).

Taxable profits.

Taxable profits estimated at 22 percent of turnover.

Distributed earnings.
Rents falling due during the year. 
Republic of Congo: Summary of Tax System, 2004

\section{Taxes}

Scope
Exemptions
Rate
Taxable Base

\section{Indirect taxes}

2.1 Value added tax (VAT) (taxe sur la valeur ajoutée).

\subsection{Excises (droits d'accises).}

\subsection{VAT surtax (centimes additionnels).}

2.4 Special tax on companies (taxe spéciale sur les sociétés); this tax is deductible from the corporate income tax.

\subsection{Tax on insurance policies (taxe sur les contrats d'assurance).}

Individuals or legal entities, including government entities engaging in taxable operations, i.e., operations associated with a business activity.

Tobacco, alcohol, jewelry, worked gold, passenger cars, and consumer electronics.

\section{All goods and services} subject to the VAT.

Business corporations, limited liability corporations, and limited equity partnerships.

Insurance companies.
Sale of locally produced items by farmers, fishermen, and hunters.

Sale of philatelic items (figurines postales),

Printing and imports of newspapers.

Art works

Social, medical, or educational services, and basic necessity goods.

All other goods and all services.

Goods and services exempt from the VAT.

Same exemptions and waivers as with the corporate income tax.
Normal rate: 18 percent. Zero rate for exports, international transportation, and the eucalyptus sector.
24 percent.

5 percent.

1-2 percent.
Sales value of nonexempted items, with tax credit for purchased inputs. Customs value plus duties and taxes assessed by customs, including excises.

Same tax base as the VAT.

VAT assessed on goods and services.

Overall turnover, including miscellaneous income and profits.

Reinsurance operations, 4 percent, 5 percent, insurance covering export credits, and insurance policies exempt from stamp tax and registration fees.

8 percent, or 25 percent depending on the type of policies underwritten.
Amounts payable to the insurer. 
Republic of Congo: Summary of Tax System, 2004

Taxes
Scope
Exemptions
Rate
Taxable Base

\section{Taxes on professional activities}

\subsection{Business}

license tax (contribution des patentes).
Individuals or legal entities engaging in an industrial, commercial, noncommercial, or artisanal activity.

\subsection{Liquor license} tax (contribution des licences).

\subsection{Special tax on} importers (taxe spéciale

importateur).

3.4 Tax on the rental value of business premises (taxe sur la valeur locative des locaux professionnels).

\section{Taxes on property}

4.1 Tax on improved property (contribution foncière des propriétés bâties).
Individuals or legal entities engaged in the sale of alcoholic beverages.

Parties subject to the business license tax engaging in imports of goods for domestic use.

Business establishments.

Establishments temporarily exempted from the business license tax.
Amount varies according to the license category.

Amount varies according to the items imported.

15 percent.

Fixed duties and/or variable rates depending on the activity, equipment, and personnel. business corporations, public or private poor child caring for poor children; painters, of mining concessions.

Nonalcoholic beverages.
Activity engaged in, equipment used, or number of employees.
Rent paid. Rental value.
Developed property built on masonry foundations; uncultivated land for commercial or industrial use; and equipment belonging to establishments permanently attached to the ground.
Real estate owned by central or local government; embassy hotels; buildings reserved for public worship; buildings reserved for education, athletic purposes, and rural farm buildings.
15-20 percent.

Rental value less 25 percent for properties used for business purposes. Land registry value less 25 percent in the case of properties used for residences. 
Republic of Congo: Summary of Tax System, 2004

\section{Taxes}

4.2 Tax on

unimproved

property

(contribution

foncière des

propriétés non

bâties).

\subsection{Tax on}

company

passenger cars

(taxe sur les

véhicules de

tourisme des

sociétés).

\subsection{Land tax (taxe sur les terrains).}

4.5 Tax on television sets (taxe sur les récepteurs de télévision).

\section{Payroll taxes}

5.1 Lump-sum payroll tax (taxe forfaitaire).

Payable on the same due dates as the IRPP.

\subsection{Apprenticeship tax (taxe d'apprentissage)}

\section{Miscellaneous undeveloped properties.}

Entities subject to the corporate income tax.

Common land. Land undeveloped or insufficiently developed. Unutilized land.

Levied on owners of television sets and radios.

Employers and payers of annuities.

Levied on public or private enterprises of one employee or more.
Roads, streets, and thoroughfares; property owned by central or local government; and surface area of mines or tracks.

Passenger cars that are more than 10 years old.
Rates fixed by

communal and

departmental councils.

CFAF 200,000-300,000. Type of vehicules.
50 percent of the land registry value. Lumpsum market value for unimproved rural properties.

Taxable Base
Land exempt from real estate tax; land not served by passable roads; and land on which construction is legally prohibited.

Public entities, schools owning television sets for eductional use.
Fixed tax assessed on the basis of the type of land in question.

CFAF 6,000 .

5 percent on total wages, plus 4 percent on the fraction exceeding $1,500,000$ per employee per year.
The state, diplomatic missions, local offices of international agencies, wages earned by the spouse of the individual smallholder, and financially independent government agencies.

At the request of enterprises engaged in training of their employees.
Surface area of the land.

Television set; radio station.
Gross amount of wages; and benefits in kind.
1 percent on total salaries and wages. 
Republic of Congo: Summary of Tax System, 2004

\section{Taxes}

Scope
Exemptions
Rate
Taxable Base

\section{Other taxes}

6.1 Registration fees (droits d'enregistrement)

6.2 Stamp taxes (contribution $d u$ timbre)
Attorneys, notaries, inheritance rights, juridical acts, donations.

Stamped paper for many legal documents in certain acts; passports; residence permits; identity cards; airline tickets.
Acts aimed for free of charge registration and for registration in balance.

Acts exempted or subjected to a special visa, or acts aimed for stamp in balance.
Fixed rates from 5,000 to 15,000 .

Value of the property of inheritance rights or value declared at the juridical act.

Fixed rates vary from Type of paper used. CFAF 1,000 to CFAF 20,000 .

Source: General Directorate of Taxes, Ministry of Economy, Finance, and the Budget.

Note: The personal income tax (item 1.1), the corporate income tax (item 1.2), and the VAT (item 2.1) generate about 90 percent of tax revenue. 